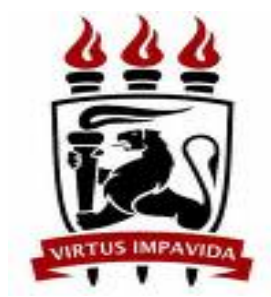

UNIVERSIDADE FEDERAL DE PERNAMBUCO

CENTRO DE FILOSOFIA E HUMANIDADES

PROGRAMA DE PÓS-GRADUAÇÃO EM DESENVOLVIMENTO E MEIO AMBIENTE

AFONSO FEITOSA REIS NETO

REDUÇÃO DO DESMATAMENTO E DA DEGRADAÇÃO FLORESTAL (REDD): bases legais para implementação na Caatinga de Pernambuco

Recife 


\section{REDUÇÃO DO DESMATAMENTO E DA DEGRADAÇÃO FLORESTAL (REDD): bases legais para implementação na Caatinga de Pernambuco}

Tese apresentada ao Programa de Pós-
Graduação em Desenvolvimento e Meio
Ambiente da Universidade Federal de
Pernambuco (PRODEMA/UFPE), como
requisito parcial para a obtenção do título de
$\begin{aligned} & \text { Doutor em Desenvolvimento e Meio } \\ & \text { Ambiente. }\end{aligned}$

Área de concentração: Gestão e Políticas Ambientais

Orientador: Prof ${ }^{a}$. Dra ${ }^{a}$. Maria do Socorro Bezerra de Araújo.

Coorientador: Prof. Dr. Everardo Valadares de Sá Barreto Sampaio. 
Catalogação na fonte

Bibliotecária Maria do Carmo de Paiva, CRB4-1291

R375r Reis Neto, Afonso Feitosa.

Redução do desmatamento e da degradação florestal (REDD) : bases legais para implementação na Caatinga de Pernambuco / Afonso Feitosa Reis Neto. 2019.

82 f. : il. ; $30 \mathrm{~cm}$.

Orientadora: Prof ${ }^{a}$. Dra ${ }^{\mathrm{a}}$. Maria do Socorro Bezerra de Araújo.

Coorientador: Prof. Dr. Everardo Valadares de Sá Barreto Sampaio.

Tese (doutorado) - Universidade Federal de Pernambuco, $\mathrm{CFCH}$.

Programa de Pós-graduação em Desenvolvimento e Meio Ambiente, Recife, 2019. Inclui referências.

1. Meio ambiente. 2. Mudanças climáticas. 3. Desmatamento. 4. Caatinga. 5. Proteção ambiental. 6. Política ambiental. I. Araújo, Maria do Socorro Bezerra de (Orientadora). II. Sampaio, Everardo Valadares de Sá Barreto (Coorientador). III. Título 


\section{REDUÇÃO DO DESMATAMENTO E DA DEGRADAÇÃO FLORESTAL (REDD): bases legais para implementação na Caatinga de Pernambuco}

Tese apresentada ao Programa de Pós-
Graduação em Desenvolvimento e Meio
Ambiente da Universidade Federal de
Pernambuco (PRODEMA/UFPE), como
requisito parcial para a obtenção do título de
$\begin{aligned} & \text { Doutor em Desenvolvimento e Meio } \\ & \text { Ambiente. }\end{aligned}$

Aprovada em: 08/05/2019.

\section{BANCA EXAMINADORA}

Prof $^{a}$. Dra. Maria do Socorro Bezerra de Araújo (Orientador) Universidade Federal de Pernambuco

Prof ${ }^{\circ}$. Dr. Everardo Valadares de Sá Barreto Sampaio (Coorientador)

Universidade Federal de Pernambuco

Prof $^{a}$. Dra. Maria do Carmo Martins Sobral (Examinador Interno/PRODEMA) Universidade Federal de Pernambuco

$$
\begin{gathered}
\text { Prof }^{\mathrm{o}} \text {. Dr. Leônio José Alves da Silva (Examinador Externo) } \\
\text { Universidade Federal de Pernambuco }
\end{gathered}
$$

Prof $^{\mathrm{a}}$. Dra. Virgínia de Carvalho Leal (Examinador Externo)

Universidade Federal de Pernambuco/ Faculdade Nova Roma-FGV/ SEMAS-PE

Prof $^{\circ}$. Dr. José Machado Moita Neto (Examinador Interno/PRODEMA)

Universidade Federal do Piauí 


\section{RESUMO}

A conservação dos ecossistemas é um dos grandes desafios mundiais frente às mudanças climáticas. Almejando conciliar a proteção das vegetações nativas com a promoção de incentivos financeiros, aflora no cenário internacional o instrumento de Redução do Desmatamento e da Degradação Florestal (REDD). No Brasil, experiências ganham destaque, como no caso do Acre e do Mato Grosso. O estado de Pernambuco sofre as diversas consequências da ação do homem sobre o meio ambiente. Uma das ações antrópicas que contribuem para esse quadro é o desmatamento do seu ecossistema predominante: Caatinga. O bioma possui apenas $50 \%$ da sua cobertura vegetal original. Nesse sentido, Pernambuco disciplinou o instrumento na Lei Estadual $n^{\circ}$ 15.809/2016. O presente estudo possui como objetivo geral analisar a possibilidade de implantação do instrumento REDD na Caatinga, tendo como objetivos específicos (I) caracterizar os aspectos legais para a efetivação em Pernambuco, (II) analisar as principais características (financiamento, áreas e beneficiários) para implementação da REDD e (III) examinar as salvaguardas propostas para implementação da REDD na Caatinga de Pernambuco. Para o primeiro objetivo foram analisados os diplomas legais e as publicações (oficiais e extraoficiais) relativas à concretização desse modelo na esfera estadual. Em relação ao segundo, foi utilizado o método comparativo tendo como referência as leis do Acre e do Mato Grosso. No terceiro objetivo as salvaguardas foram examinadas com base na metodologia REDD Safeguard Spectrum Framework (RSS Framework). Os resultados demonstram que é possível a implantação deste instrumento em Pernambuco, dada a existência de todo um arcabouço legal criado para sua efetivação que vai desde a definição de responsabilidades até o desenvolvimento de um arranjo institucional. Todavia, a lei pernambucana deixou de avançar em muitos pontos, principalmente na forma de atuação quanto ao financiamento, a diversidade das áreas e inclusão dos direitos do carbono para beneficiar as comunidades locais. Por fim, as salvaguardas definidas possuem, em grande parte, um caráter abstrato, baseados em princípios gerais, dificultando seu monitoramento e aplicação.

Palavras-chave: Legislação Pernambucana. Mercado de Carbono. Salvaguardas na REDD. Proteção da Caatinga. Áreas receptoras. 


\begin{abstract}
Conservation of ecosystems is one of the major global challenges facing climate change. Aiming to reconcile the protection of native vegetation with the promotion of financial incentives, the instrument for Reducing Deforestation and Forest Degradation (REDD) is emerging in the international scenario. In Brazil, experiences gain prominence, as in the case of Acre and Mato Grosso. The state of Pernambuco undergoes the various consequences of human action on the environment. One of the anthropic actions that contribute to this situation is the deforestation of its predominant ecosystem: Caatinga. The biome has only $50 \%$ of its original vegetation cover. In this sense, Pernambuco disciplined the instrument in State Law $n^{\circ} 15.809 / 2016$. The objective of this study is to analyze the possibility of implementing the REDD instrument in the Caatinga, with specific objectives (I) to characterize the legal aspects to be effective in Pernambuco, (II) to analyze the main characteristics (financing, areas and beneficiaries) for implementation of REDD and (III) to examine the proposed safeguards for REDD implementation in the Caatinga of Pernambuco. For the first objective, the legal diplomas and publications (official and non-official) related to the implementation of this model at the state level were analyzed. In relation to the second, the comparative method was used having as reference the laws of Acre and Mato Grosso. In the third objective the safeguards were examined based on the REDD Safeguard Spectrum Framework (RSS Framework) methodology. The results demonstrate that it is possible to implement this instrument in Pernambuco, given the existence of a legal framework created for its implementation, from the definition of responsibilities to the development of an institutional arrangement. However, Pernambuco's law has failed to advance in many areas, especially in terms of financing, the diversity of areas and the inclusion of carbon rights to benefit local communities. Finally, defined safeguards are largely abstract in character, based on general principles, making it difficult to monitor and enforce them.
\end{abstract}

Keywords: Pernambuco Legislation. Carbon Market. REDD Safeguards. Caatinga Protection. Receiving areas. 


\section{LISTA DE ILUSTRAÇÕES}

$\begin{array}{lll}\text { Figura } 1-\quad \text { Ecorregiões do Brasil } & 27\end{array}$

Figura 2 - Mesorregiões de Pernambuco 31

Figura 3 - $\quad$ Espectro de salvaguardas da REDD 38

Figura 4 - $\quad$ Componentes, eixos e áreas de atuação do Plano Estadual do 44 Clima

Figura 5 - $\quad$ Recorte do cronograma previsto no Plano e diversidade de 45 atores envolvidos na implementação das metas

Figura 6 - Arranjo institucional da PEPSA 50

Figura 7 - Caatinga pernambucana e áreas potenciais para a REDD $\quad 61$

Quadro 1 - $\quad$ Características da REDD em Pernambuco, Acre e Mato Grosso $\quad 68$

Figura 8- Salvaguardas da PEPSA $\quad 69$

Figura 9 - $\quad$ Análise das Salvaguardas presentes PEPSA pela metodologia 70 RSS Framework 


\section{LISTA DE SIGLAS E ABREVIATURAS}

APP

BNDES

CAR

CDB

$\mathrm{CF} / 88$

CNUMAD

COP

CQNUMC

CREDD

ENREDD

FAO

FEMA

ICMBIO

IPCC

MDL

MRV

PEEMC

PEPSA

PNMC

PSA

REDD

$\mathrm{RL}$

RPPN

SISCAR

$\mathrm{UC}$

UNFCCC
Área de Preservação Permanente

Banco Nacional de Desenvolvimento Econômico e Social

Cadastro Ambiental Rural

Convenção sobre Diversidade Biológica

Constituição Federal Brasileira de 1988

Conferência das Nações Unidas sobre Meio Ambiente e Desenvolvimento

Conferência das Partes

Convenção-Quadro das Nações Unidas sobre Mudança do Clima

Certificados de Redução de Emissões por Desmatamento e Degradação

Estratégia Nacional de REDD

Organização das Nações Unidas para Alimentação e Agricultura

Fundo Estadual de Meio Ambiente

Instituto Chico Mendes de Conservação e Biodiversidade

Painel Intergovernamental sobre Mudança Climática

Mecanismo de Desenvolvimento Limpo

Medição, Registro e Verificação

Política Estadual de Enfretamento as Mudanças Climáticas

Política Estadual de Pagamentos por Serviços Ambientais

Política Nacional sobre Mudança Climática

Pagamentos por Serviços Ambientais

Redução do Desmatamento e da Degradação Florestal

Reserva Legal

Reserva Particular do Patrimônio Natural

Sistema Nacional de Cadastro Ambiental Rural

Unidades de Conservação

United Nations Framework Convention on Climate Change 


\section{SUMÁRIO}

1 INTRODUÇÃO 9

2 OBJETIVOS 12

2.1 OBJETIVO GERAL 12

2.2 OBJETIVOS ESPECÍFICOS 12

3 REFERENCIAL TEÓRICO

3.1 HISTÓRICO DA REDD 13

3.2 CARACTERÍSTICAS GERAIS DA REDD 17

$\begin{array}{lll}\text { 3.2.1 Financiamento } & 17\end{array}$

3.2.2 Salvaguardas 21

3.2.3 REDD no Brasil: Acre e Mato Grosso 24

3.3 CAATINGA PERNAMBUCANA 26

4 METODOLOGIA $\quad 34$

4.1 CARACTERIZAÇÃO DOS ASPECTOS LEGAIS 34

4.2 ANÁLISE DAS CARACTERÍSTICAS DA IMPLEMENTAÇÃO 35

4.3 ANÁLISE DAS SALVAGUARDAS PROPOSTAS NA PEPSA 37

$5 \quad$ RESULTADOS E DISCUSSÃO 41

5.1 PARÂMETROS LEGAIS DA REDD EM PERNAMBUCO 41

5.2 CARACTERÍSTICAS DA REDD EM PERNAMBUCO 53

5.2.1 Financiamento na PEPSA

5.2.2 Áreas receptoras: Caatinga pernambucana $\quad 60$

5.2.3 Beneficiários: direitos do carbon $\quad 65$

5.3 SALVAGUARDAS REDD: PERNAMBUCO 69

6 CONCLUSÃO

REFERÊNCIAS $\quad 76$ 


\section{INTRODUÇÃO}

A Caatinga é o único bioma exclusivamente brasileiro e compreende uma área de $844.453 \mathrm{~km}^{2}$ do território nacional (IBGE, 2010). O ecossistema tem sido descrito historicamente como pobre em espécies e com baixo grau de endemismo, o que certamente é reflexo do pouco conhecimento sobre a região, visto ser o bioma no Brasil com menor número de inventários (SILVA et al., 2017). As características peculiares e ainda pouco estudadas da Caatinga, assim como a vulnerabilidade de seu sistema mais árido juntamente com a intensa pressão antrópica, não tem se refletido na sua proteção o que potencializa os impactos gerados pelas mudanças climáticas (SILVA et al., 2018).

A situação de Pernambuco é um caso interessante para análise quanto à vulnerabilidade ocasionada pelos efeitos da mudança do clima e a importância de uma legislação estadual que se adeque a sua situação. O Estado possui superfície territorial de, aproximadamente, $98.146 \mathrm{~km}^{2}$ abrigando uma grande diversidade de ecossistemas. Cerca de 8 mil espécies de organismos foram registradas e, como muitos grupos ainda não foram estudados, estima-se que este número varie entre 24 mil e 90 mil (PERNAMBUCO, 2011). Tamanha diversidade biológica contrasta com os altos níveis de degradação dos ecossistemas da Mata Atlântica e da Caatinga, dos quais restam apenas $12 \%$ e $50 \%$ de suas coberturas originais, respectivamente (PERNAMBUCO, 2011; S.O.S MATA ATLÂNTICA, INPE, 2015).

As regiões do Agreste e Sertão, locais em que a Caatinga é predominante, apresentam grande pressão antrópica sobre os recursos naturais, especialmente os florestais. A ação do homem verifica-se em áreas degradadas pelo consumo da lenha e pelo intenso processo de urbanização, tanto da Região Metropolitana quanto nos outros polos econômicos, como a região do Araripe (PERNAMBUCO, 2011).

É evidente o passivo ambiental acumulado que incide sobre o Estado, sendo considerado pelo Painel Intergovernamental sobre Mudanças Climáticas - IPCC, um "hotspot" mundial em relação às alterações do clima (SILVA et al., 2018). As regiões do Sertão e do Agreste padecem do fenômeno das secas juntamente com o processo de desertificação, que potencializam o surgimento de grupos denominados refugiados e/ou deslocados ambientais (AMORIM; BARROS, 2017).

Pernambuco possui 135 municípios nas áreas suscetíveis à desertificação (ASD), onde vivem mais de 2,5 milhões de habitantes, conformando uma densidade demográfica de 35,34 $\mathrm{hab} / \mathrm{km}^{2}$. Este quadro poderá levar a processos migratórios, deslocando as populações 
afetadas para os centros urbanos, sobrecarregando seus serviços e agravando ainda mais a condição socioeconômica (PERNAMBUCO, 2011).

As medidas de comando e controle empregadas para conter a retirada ilegal de madeira da Caatinga carecem de aprimoramento e poderiam contribuir para reduzir os índices do desmatamento que subsistem elevados (SILVA et al., 2018). Contudo, é cada vez mais evidente que tais medidas possuem limites e que necessitam ser complementadas com o emprego de instrumentos econômicos para conservação.

Os incentivos econômicos e os arranjos institucionais decorrentes da sua implantação podem complementar a estrutura político-institucional de proteção às florestas que vem sendo desenvolvida no Brasil, de forma a garantir as conquistas já obtidas e avançar mais na redução das taxas de desmatamento (SATHLER et al., 2015).

Um instrumento que tem como objetivo contemplar essa demanda é a Redução de Desmatamento e da Degradação Florestal (REDD) que visa, por meio de incentivos financeiros, proteger a vegetação nativa (ENREDD, 2016). Em termos conceituais, Reis Neto et al. (2017) argumentaram que o entendimento da REDD evoluiu desde que foi proposto em discussões internacionais. Na tentativa de satisfazer interesses diferentes e por vezes contraditórios, o conceito foi paulatinamente modificado tendo sido interpretado de diversas formas por diferentes grupos, dependendo do contexto, objetivos e interesses de quem o define.

Essa pluralidade de interesses fica evidenciada quando é levada em conta a diversidade das iniciativas fomentadas no mecanismo. De acordo com as diretrizes adotadas desde a Conferência das Partes 16 (COP 16) em Cancún (UNFCCC, 2016) esse instrumento deve abranger uma ampla gama de iniciativas, desde ações locais de uso da terra adotadas por proprietários ou comunidades rurais até ações específicas e amplas envolvendo monitoramento, capacitação, esclarecimento da posse da terra, bem como fortalecimento da governança florestal (ANGELSEN et al., 2018). Sua característica multifacetada é uma das vantagens mas também entrave para a efetivação.

No Brasil, Estados progrediram, nos últimos oito anos, na construção de sistemas jurisdicionais para o combate do desmatamento. Alguns deles, como Acre e Mato Grosso, estabeleceram inclusive metas de redução de desmatamento e aprovaram legislações próprias para regulamentar a REDD (AMARANTE; RUIVO, 2013). Na mesma linha, o governo brasileiro divulgou, no início de 2016, sua estratégia nacional (ENREDD).

Apesar dos variados benefícios concebidos na teoria (manejo florestal, conservação dos estoques de carbono, participação das comunidades), são crescentes as evidências que 
apontam para uma complexidade de fatores envolvidos que impedem a efetividade de sua implementação, sendo esta alcançada "cuando logre cumplir a cabalidad el propósito por el cual fue creada" (CHACÓN, 2016, p.3). Problemas ligados à propriedade das terras, distribuição de renda, transparência nas informações, participação popular, definição de competências e respeito as salvaguardas ainda são recorrentes em diversos países (TONI, 2011).

A discussão é crucial não apenas para entender até que ponto a REDD cumpre ou não suas promessas, mas também para fornecer contribuições e lições dos próprios processos de concepção/implementação dessa iniciativa. Essa preocupação com as florestas justifica-se pela sua importância na manutenção de serviços ambientais, a exemplo do ciclo da água e do estoque de carbono (REIS NETO et al., 2017).

A Lei Estadual no 14.090/10 (Política Estadual de Enfrentamento das Mudanças Climáticas - PEEMC) juntamente com seu plano e a Lei Estadual n 15.809/16 (Política Estadual de Pagamento por Serviços Ambientais - PEPSA) revelam-se como os principais instrumentos do Governo de Pernambuco para combater as alterações do clima. Tais iniciativas podem ser entendidas como uma resposta à fragilidade que o Estado possui frente às modificações, tendo em vista que consequências são sentidas em diversas regiões. Como resultado, Pernambuco ganhou uma série de programas voltados às mudanças climáticas e ampliou o orçamento de outros já existentes na esfera ambiental.

Dentre esses instrumentos desenhados pela PEEMC e refinados pela PEPSA está a REDD. Criado no âmbito internacional nas denominadas Conferência das Partes (COPs), esse mecanismo baseia-se na concepção de Pagamento por Serviços Ambientais (PSA) e visa através de incentivos de mercado (créditos de carbono) conter as taxas crescentes de redução da área florestal, tomando como base áreas nativas remanescentes na paisagem (ANGELSEN, 2008).

Cabe ressaltar que no caso da Caatinga pernambucana a avaliação dos processos sociais, econômicos e demográficos é fundamental para formulação e implementação de políticas públicas que busquem o desenvolvimento sustentável regional e local. Outrossim, é útil para identificação de áreas e de modelos da REDD que atendam às necessidades peculiares e não sejam meros padrões exógenos importados para aplicação direta sem nenhum tipo de adaptação, sob risco de elaboração de mais uma lei ambiental sem efeitos práticos (CHACÓN, 2016) e consequente aumento do desmatamento num futuro próximo. 


\section{OBJETIVOS}

\subsection{OBJETIVO GERAL}

Analisar a possibilidade de implementação do instrumento REDD na Caatinga pernambucana

\subsection{OBJETIVOS ESPECÍFICOS}

- Caracterizar os aspectos legais ligados à implantação da REDD em Pernambuco;

- Analisar as características da implementação da REDD na Caatinga de Pernambuco;

- Examinar as salvaguardas propostas para implementação da REDD em Pernambuco. 


\section{REFERENCIAL TEÓRICO}

Nesta seção serão apresentados os tópicos referentes a evolução temporal da REDD nos acordos e tratados internacionais, as características fundamentais na implementação da REDD (financiamento e salvaguardas), a aplicação do mecanismo no Brasil bem como as principais elementos socioambientais da Caatinga pernambucana que devem ser levados em consideração nos projetos de conservação do bioma.

\subsection{HISTÓRICO DA REDD}

Há mais de 20 anos tem sido discutida, em âmbito internacional, a elevação da concentração de gases de efeitos estufa na atmosfera, em decorrência de ações humanas, diante do risco associado às mudanças climáticas, seja para países desenvolvidos seja para aqueles em desenvolvimento (MMA, 2016). A incerteza quanto a esse aspecto existente à época do Relatório Brundtland e da assinatura da Convenção-Quadro sobre Mudança do Clima (UNFCCC, sigla em inglês) aos poucos foi cedendo espaço para uma maior convicção da comunidade científica que, até os dias atuais, não é unânime.

A pressão sobre as florestas tropicais, exercida pelo crescimento das cidades, das áreas de cultivo agrícola e de produção de animais, entre outros fatores, tem levado a comunidade internacional a discutir instrumentos econômicos com o propósito de conter a conversão para usos alternativos do solo das áreas florestadas (PERTERSEN et al., 2018).

Em termos gerais, os instrumentos albergados pelo Direito Ambiental podem ser de duas matizes: (i) comando e controle ou (ii) econômicos (MILARÉ, 2013). Em resumo, os primeiros são as regras postas que, em tese, captando os valores da sociedade, definem limites da atuação do homem. Atuam com forte presença do denominado poder de polícia estatal, tendo em vista que limitam as liberdades individuais em prol do bem-estar coletivo.

Entretanto, ao longo da jornada pela implementação da proteção ambiental, percebeuse que a simples proibição de desmatamento, por exemplo, não era suficiente para frear a pressão sobre as florestas. Desse modo, buscaram-se instrumentos econômicos capazes de complementar os limites das ferramentas de comando e controle, por meio de incentivos financeiros. No entanto, a concretização de um desenvolvimento verdadeiramente sustentável exige a utilização equilibrada de instrumentos de comando e controle, juntamente com mecanismos econômicos.

$\mathrm{Na}$ Convenção do Clima, respondendo as novas demandas da relação meio ambiente/sociedade, a implementação desse tratado internacional propõe a concessão de incentivos econômicos para as atividades que reduzem o desmatamento e a degradação 
florestal, contribuindo para o incremento de boas práticas de conservação/restauração que resultem em aumento do estoque de carbono (MMA, 2016). O referido instrumento ficou conhecido pela siga REDD.

A REDD é baseada no princípio denominado protetor-recebedor, que propõe o pagamento àqueles agentes cuja ação promove o incremento dos serviços ambientais prestados pela natureza. Segundo Nusdeo (2012) e Sirvinskas (2017), trata-se de um mecanismo de internalização das externalidades positivas. O princípio é sempre analisado em contraposição ao consolidado princípio do poluidor-pagador, que também consiste, em última análise, na assimilação e consequente internalização pelo sistema produtivo das chamadas externalidades negativas (falhas de mercado) que são os efeitos sociais, econômicos e ambientais indiretamente causados pela venda de um produto ou serviço.

Para compreender os objetivos do mecanismo assim como sua evolução no mercado internacional cabe uma breve retrospectiva. Como reconhecimento da relevância do fenômeno do aquecimento global em âmbito mundial, além do Relatório Brundtland, foram fatores de fundamental importância a assinatura de declarações regionais exigindo adoção de medidas para contenção das mudanças climáticas (PAMELA; PUSHPENDRA, 2017), bem como a criação do Painel Intergovernamental de Mudanças do Clima (IPCC, sigla em inglês), em 1988, que consiste na reunião de diversos cientista do mundo para discutir evidências das alterações climáticas.

Outrossim, a assinatura da UNFCCC, no ano de 1992, durante a Cúpula da Terra, no Rio de Janeiro, também é um marco que merece ser destacado. Essa convenção foi assinada com o propósito de alcançar a estabilização das concentrações de gases de efeito estufa na atmosfera num nível que impeça uma interferência antrópica perigosa no sistema climático (NUSDEO, 2012). Esse nível deve ser alcançado, de acordo com a Convenção, em um prazo suficiente que permita aos ecossistemas adaptarem-se naturalmente às mudanças do clima, assegurando que a produção de alimentos não seja ameaçada, permitindo o desenvolvimento econômico de maneira sustentável.

A Convenção estabelece obrigações comuns a todos os signatários, como elaborar inventários nacionais de emissões, formulação de programas nacionais que incluam medidas para mitigar a mudança do clima entre outros. No sistema de governança instituído pela UNFCCC, a Conferência das Partes (COP) é o órgão supremo, criado com o objetivo de examinar regularmente a implementação das medidas acordadas, além de tomar as decisões necessárias para promover a sua efetiva implementação. 
Durante a COP 3, em 1997, em Quioto no Japão, os países signatários adotaram um protocolo complementar à Convenção, contendo compromisso mais rigorosos para a contenção das alterações no clima. Nessa COP foi prevista a criação do comércio de emissões do chamado Mecanismo de Desenvolvimento Limpo (MDL) no qual os países desenvolvidos se comprometem em apoiar projetos nos países do anexo II (em desenvolvimento) para contribuir com o cumprimento de parte de seus compromissos quantificados de limitação de redução das emissões.

Nesse sentido, prevaleceu, portanto, a lógica dos mecanismos econômicos na busca pelo cumprimento dos objetivos do Protocolo de Quioto. De acordo com Mbatu (2016), os mecanismos ajudam a estimular investimentos verdes e auxiliam as partes a encontrar seus limites de emissão em um ritmo de mudanças tecnológica e produtiva compatível com o movimento do mercado.

Em linhas gerais, os direitos ligados aos instrumentos econômicos, principalmente o crédito de carbono, trata-se de conferir direitos privados de apropriação de bens coletivos mediante o pagamento de um preço, estimulando um mercado liberal idealizado na “disponibilidade a pagar" dos sujeitos envolvidos.

Segundo Irawan e Tacconi (2013), embora não se possa ignorar o avanço na regulação internacional das mudanças climáticas, os mecanismos previstos no Protocolo de Quioto são limitados no seu objetivo de reduzir a emissão de gases de efeito estufa, visto que adotam a lógica de mercado de transferência de emissões. Sather et al. (2015) afirmaram que esse sistema gera controvérsias na medida em que não garante a redução das emissões, mas apenas a transferência do direito de emissão conforme as regras de livre mercado.

Ainda nessa seara, outra importante limitação desse sistema é a sua incapacidade de assimilar os custos e benefícios sociais que não podem ser expressos em moeda que acabam ficando fora dessa análise que é feita exclusivamente sob a lógica de mercado. Com efeito, a redução da análise econômica a uma precificação acaba por ignorar outros valores dos bens ambientais (social, cultural, estético).

Apesar das suas lacunas e entraves, é inevitável e necessário que a norma ambiental caminhe em sintonia com a lógica do mercado, tendo em vista que a sociedade, em parte, é guiada pela satisfação de objetivos econômicos. Contudo, essa sintonia pode transformar-se à luz de uma racionalidade ambiental com vistas a garantir a sustentabilidade do próprio sistema econômico. Daí resulta a relevância da utilização de instrumentos econômicos que possam colaborar com esse propósito. 
Essa nova acepção da relação meio ambiente-sociedade foi o espaço propicio para o surgimento da REDD que consiste na redução de emissões decorrentes de desmatamento e a degradação florestal. A proposta inicial ocorreu na COP 9 (2003), realizada em Milão, de maneira ainda difusa e capitaneada por instituições não governamentais brasileiras. Foi somente na COP 11 (2005), em Montreal, que um bloco de nações em desenvolvimento apresentou uma proposta para discutir formas de incentivos econômicos ligados diretamente a redução do desmatamento nos países em desenvolvimento detentores de florestas tropicais.

A REDD só foi reconhecida oficialmente como um instrumento desenvolvido na UNFCCC na COP 13 (2007), em Bali (MBATU, 2016). As Partes decidiram no "Plano de Bali" iniciar um processo que permitisse a aplicação plena, eficaz e sustentável da Convenção, abordando, entre outros aspectos, a intensificação do esforço para a mitigação das mudanças climáticas mediante um exame mais profundo das abordagens políticas e incentivos positivos para redução das emissões provenientes da degradação florestal.

Em Cancún, durante a COP 16 (2010), foram estabelecidos contornos mais concretos ao instituto. Os países em desenvolvimento foram incentivados a contribuir com a mitigação no setor florestal adotando as seguintes medidas, de acordo com suas capacidades e circunstâncias nacionais: (a) redução das emissões decorrentes do desmatamento; (b) redução das emissões decorrentes da degradação florestal; (c) conservação das reservas florestais de carbono; (d) gestão sustentável das florestas; (e) incremento das reservas florestais de carbono (ANGELSEN et al., 2018).

Os "Acordos de Cancún" também estabeleceram que as atividades relativas à REDD devem ser adotadas em três etapas: (i) elaboração de estratégias ou planos de ação, políticas e estratégias nacionais juntamente com atividades de fomento (ii) aplicação das políticas e medidas nacionais que poderiam incorporar novas estratégias baseadas em resultados; e por fim (iii) execução de medidas baseadas em resultados, que deve ser objeto de medição, registro e verificação (MRV) (MMA, 2016).

Nesse mesmo documento também foram estabelecidas as salvaguardas socioambientais, num total de sete, que almejam garantir a real busca pela compatibilização entre o meio ambiente, a economia e o aspecto social da REDD. Outro passo importante na curta trajetória da REDD foi em Doha, COP 18 (2012), em que foram discutidos as formas de financiamento e os arranjos institucionais necessários para esse mecanismo (ANGELSEN et al., 2018).

Independente das propostas existentes a respeito do marco regulatório e sua evolução, a REDD se apresenta não como a melhor solução e sim como mais uma ferramenta para 
integrar os diferentes olhares dentro da perspectiva climática. Seja no âmbito da UNFCCC seja no mercado voluntário, o fato é que múltiplos benefícios podem ser associados ao desenvolvimento do mecanismo. Entre estes, pode-se destacar além do carbono em si, a contribuição para conservação da biodiversidade e a potencialidade para incorporação de práticas sociais relacionadas às comunidades dependentes das florestas.

Nesse contexto, verifica-se uma possibilidade de relação entre as mudanças climáticas e a conservação da biodiversidade, permitindo uma integração entre a Convenção do Clima e a Convenção sobre a Diversidade Biológica (CDB). De fato, a implementação da REDD terá não apenas o condão de reduzir as emissões, mas também como resultado a conservação de todo um patrimônio socioambiental, caso seja efetivada de maneira adequada.

Seus potenciais benefícios sociais desejados pelas COPs possuem como intuito agregar à obtenção de vantagem econômica por conservação dos ecossistemas florestais, garantias de respeito às comunidades que convivem nesses ecossistemas, estimulando seu modo de vida.

Dentre desse cenário de múltiplos benefícios, apesar de não estar alheio às críticas e a aperfeiçoamentos, há que se lançar ações para a consolidação de um regime global efetivo da REDD nos próximos encontros internacionais para que este mecanismo contribua efetivamente para a mitigação das mudanças climáticas e com benefícios não associados ao carbono.

\subsection{CARACTERÍSTICAS GERAIS DA REDD}

As características da implementação da REDD são elementos fundamentais para compreender a dinâmica do instrumento. Notadamente, o financiamento e a definição das salvaguardas são peças integrantes desse sistema. Portanto, assimilar esses conceitos torna-se imprescindível para o pleno desenvolvimento da REDD em qualquer cenário que possui como fim a conservação da vegetação nativa.

\subsubsection{Financiamento}

Aproveitar o potencial das florestas para mitigar as mudanças climáticas requer financiamento para cobrir os custos da modificação de políticas e práticas, bem como para fornecer incentivos financeiros para a transição. Os recursos permitem que os países/estados melhorem a governança florestal, desenvolvam estratégias e instituições próprias, possibilitem que as partes interessadas invistam nas florestas e adquiram as habilidades/tecnologias para 
monitorar, registrar e verificar (MRV) o carbono sequestrado pelas florestas (ANGELSEN et al., 2018). Todavia, a obtenção desses recursos ainda é um grande entrave.

De acordo com Umunay et al. (2018), diferentes instrumentos dão ênfase a diferentes objetivos de política ambiental e não há um instrumento capaz de atingir igualmente objetivos de melhoria ambiental, redução de custos e aumento de equidade. Neste contexto, atualmente, tem se tornando mais comum a adoção de uma abordagem mista pelos elaboradores de políticas, com o uso de múltiplas ferramentas, incluindo tanto regulação direta quanto instrumentos econômicos (NEPSTAD et al., 2018).

A REDD enquadra-se no segundo grupo, apresentando compensação pelo desmatamento evitado, remunerando indivíduos, comunidades, projetos e/ou países pelos benefícios de mitigação das mudanças climáticas trazidos pela manutenção de suas "florestas em pé" (vegetação nativa), que representam emissões evitadas de gases de efeito estufa (VILLA et al., 2018). Entrou em vigor, numa abordagem mais complexa, dentro da Convenção Quadro das Nações Unidas para Mudanças Climáticas (UNFCCC, sigla em inglês), como parte do Acordo de Paris, no ano de 2015. O Art. $5^{\circ}$ declara explicitamente que as partes signatárias devem agir para conservar e melhorar os sumidouros/reservatórios de gases de efeito estufa, incluindo florestas (UNFCCC, 2017). A UNFCCC também estabeleceu que, dentro da REDD, o Green Climate Fund (GCF) será a entidade operacional inicial para financiamento no âmbito da Convenção.

O Art. $6^{\circ}$ do mesmo documento estabelece a base para um mecanismo de mercado para incentivar iniciativas de mitigação, mas não menciona nem define regras específicas para a REDD (UNFCCC, 2017). Assim, tanto o Acordo de Paris, nos Art. $5^{\circ}$ e $6^{\circ}$, quanto a COP 21 (2015) , em sua Decisão 1 (parágrafo 54), deixam abertas as possibilidades para que os diferentes mecanismos de financiamento operem, não restringindo a um único modelo de custeamento (STRECK; RAJÃO, 2017).

Atualmente são empregados diversas estruturas para captação de recursos: via setor privado, principalmente o Voluntary Carbon Market, que se desenvolveu independentemente das negociações da UNFCCC (SALLES et al., 2018) e via fundos públicos, representados, por exemplo, pelo Fundo Amazônia, um mecanismo do governo brasileiro criado para fornecer financiamento para iniciativas ligadas às florestas, inclusive a REDD (BNDES, 2014; VIANA, 2009).

Cabe destacar que alguns países representaram uma grande parte do financiamento público internacional; entre 2008 e 2015, 87\% da assistência oficial ao desenvolvimento para 
atividades explicitamente rotuladas como REDD foram investidos pela Noruega, Alemanha, Reino Unido, Estados Unidos e Austrália (SALLES et al., 2018; BNDES, 2014).

Esses fundos públicos podem ser criados pelo próprio país/estado para financiar as iniciativas REDD ou podem ser desenvolvidos por outros países visando subsidiar os países em desenvolvimento, a exemplo do Brasil. Esses fundos públicos internacionais podem ser feitos de maneira direta entre as partes envolvidas (financiador e destinatário) ou idealizados por meio de fundos multilaterais. Esses fundos multilaterais são geridos por instituições como (OLESEN et al., 2018): Banco Mundial, Programa UN-REDD, Global Environment Facility (GEF) e Green Climate Fund (GCF). Para os doadores, esses mecanismos multilaterais garantem um alto nível de governança e menores custos de transação (em comparação com o envolvimento direto com os países destinatários) e oferecem aos doadores um certo grau de controle sobre como os mecanismos do fundo são governados. No entanto, as exigências formais rígidas impostas por esses fundos são desafiadoras para os destinatários e levam a altos custos de transação e necessidades de capacitação (OLESEN et al., 2018; VIANA, 2009).

Dessa forma, as características de financiamentos (públicos e/ou privadas) discutidas em relação ao instrumento estão diretamente ligadas às diversas particularidades que impactam na concepção e na estrutura da REDD. Por exemplo, salvaguardas utilizadas, envolvimento dos participantes, condicionalidade de incentivo, cobertura de ações e práticas de MRV das emissões (SALLES et al., 2018; ANGELSEN et al., 2018; NEPSTAD et al., 2018).

As abordagens adotadas em relação às essas características são cruciais para a configuração de propostas e experiências da REDD e, como tal, têm sido parte de um intenso debate teórico e político sobre qual seria a melhor estrutura para esse mecanismo (VILLA et al., 2017; STRECK; RAJÃO, 2017). A REDD, na forma como vem se consolidando internacionalmente, é, em sua essência, um sistema financeiro, com características específicas desse universo (SALLES et al., 2018). Sua estrutura baseia-se em pagamento de fluxo de floresta, ou seja, na verificação da efetiva redução de emissão de gases de efeito estufa (LIBERT AMICO; TRENCH, 2016) e, nessa condição, não contempla, por si só, uma proteção ampla das realidades da Caatinga - que são muito diversas, possuem dinâmicas sociais próprias e culturas fortemente enraizadas, bem como uma diversidade de identidades que precisam ser preservadas (o que não se consegue tão somente com o pagamento da redução de emissões) (SILVA et al., 2018). 
Essas características demonstram a necessidade de se alinhar as ações e normas locais com os princípios internacionalmente estabelecidos, bem como com a legislação nacional/estadual, para que, ao mesmo tempo, exista o cumprimento legal e a obtenção de recursos, seja de maneira pública seja de maneira privada (STRECK; RAJÃO, 2017). Pretende-se, desta forma, regulamentar duas realidades com dinâmicas bastante distintas: uma esfera estritamente financeira, que segue regras de mercado, de natureza privada, representada pelo mercado de carbono; e uma esfera primordialmente pública, cujas políticas seguem padrões de consenso político, essencialmente social em sua teoria, representada por políticas públicas que almejam a conservação de ecossistemas (SALLES et al., 2018).

Cuida-se, em síntese, de uma proposta de um "adaptador" ou um "conector" entre o sistema internacional de pagamento por REDD com a realidade local e suas características socioambientais, sem, contudo, desvirtuar a essência do mecanismo. Em última instância é possível diferenciar entre as "Ações REDD” em si e os mecanismos de incentivo usados para fomentá-las.

Por exemplo, o Código Florestal (Lei Federal n 12.651/12) pode ser considerado um elemento propulsor para implementação do mecanismo em razão da previsão do Cadastro Ambiental Rural (CAR), assim como as linhas de financiamento criadas pelo BNDES para incentivar a preservação de vegetação nativa dentro do imóvel por meio de regularização fundiária. Assim, o financiamento pode se dar tanto em razão de investimento em "Ações REDD" de maneira direta (certificados de redução) quanto em práticas que possam fomentar o caminho para aplicação do instrumento.

Segundo a abordagem da UNFCCC (2017), no âmbito REDD serão incentivadas atividades para a provisão dos serviços ambientais relacionados ao carbono. Mas também devem ser oferecidos incentivos para a implantação de outros elementos, incluindo instrumentos regulatórios e arranjos institucionais, como estratégias setoriais, sistemas para MRV e cumprimento de salvaguardas sociais e ambientais.

O financiamento da REDD tem sido foco de um amplo debate ao longo das negociações (REIS NETO et al., 2017), e pode ocorrer por meio de diferentes modalidades. Por exemplo, pode tanto ser feito com a comercialização de reduções (créditos) de carbono florestal entre atores privados em um mercado de carbono, quanto com o estabelecimento de fundos públicos de financiamento (VIANA, 2009).

Para Salles et al. (2018) a REDD seria um policy mix, uma macro política que inclui um instrumento de PSA, pois como parte da REDD estão previstas estratégias 
nacionais/estaduais que incluem, além de um PSA, um amplo conjunto de práticas, como ordenamento fundiário e melhor gerenciamento de áreas protegidas.

Justifica-se, dessa forma, expandir o conhecimento sobre as modalidades de financiamento REDD e seus possíveis impactos na implantação do mecanismo, temas que estão no cerne de um intenso debate, teórico e político, em curso sobre quais estruturas são mais indicadas para conferir eficácia e eficiência (CHACÓN, 2016) ao mecanismo no caso de Pernambuco e mais especificamente na Caatinga.

\subsubsection{Salvaguardas}

Uma questão fundamental na implementação da REDD é a análise da situação preexistente de desigualdade entre pessoas que moram perto de florestas ou se utilizam-se de seus recursos florestais. A questão então é de que maneira as atuais ações reconhecem e procuram incluir elementos estruturais existentes de desigualdade como parte da criação de salvaguardas (PAMELA; PUSHPENDRA, 2017). Se não forem elaboradas com a devida atenção, os esforços da REDD podem, ainda que inadvertidamente, consolidar a desigualdade estrutural, oferecendo apenas benefícios simbólicos para as pessoas marginalizadas.

Entrar nesse instrumento significa, em termo práticos, participar de um acordo para canalizar mais recursos para os países em desenvolvimento ou projetos que implementam incentivos, políticas e financiamento para deter/reverter a perda e a degradação das florestas (MBATU, 2016). Realizado de maneira correta, oferece uma oportunidade apta para promover o manejo sustentável das florestas e reduzir as emissões relacionadas a esse setor.

Contudo, a concretização com viabilidade financeira e social das ações de REDD não vêm sendo algo simples. Em muitos países, interesses puramente econômicos e a falta de diálogo entre os diversos atores tornam o ciclo de vida dos projetos muito curto, entrando em confronto direto com as disposições da Convenção-Quadro das Nações Unidas sobre Mudança do Clima (UNFCCC, sigla em inglês).

A menos que as iniciativas da REDD possam criar uma ponte entre esses diversos grupos e estabelecer benefícios para aqueles que mais precisam, elas simplesmente não funcionarão (NEUDERT, 2018). De fato, elas podem fazer mais mal do que bem, aprofundando a pobreza e a desconfiança, esgotando a biodiversidade e até mesmo aumentando as emissões relacionadas às florestas. 
Os membros da UNFCCC reconhecem isso. Não por acaso, em 2010, eles assinaram as “Salvaguardas de REDD”, que estabelecem sete princípios ${ }^{1}$ para governos e financiadores, à medida que buscam programas para reduzir as emissões das paisagens florestais (UNFCCC, 2015). Projetado no interesse de populações dependentes de florestas, elas incluem tomada de decisão transparente, participação de comunidades locais e a proteção de pessoas/ecossistemas vulneráveis.

O setor privado e a sociedade civil, com interesse distintos, vislumbraram, no instrumento, potencial para aumentar os recursos disponíveis para proteger os ecossistemas florestais e promover o desenvolvimento sustentável (ARHIN, 2014). Atores financiadores como o Banco Mundial e a Aliança para o Clima, Comunidade e Biodiversidade (CCBA) também elaboraram, baseados no acordo de Cancún, suas salvaguardas que devem ser respeitadas para que os projetos submetidos a sua análise possam ser fomentados.

Os países/projetos que almejam a REDD e desejam receber pagamentos baseados no desempenho sob a UNFCCC são solicitados a fornecer resumos de informações sobre como as salvaguardas estão sendo "tratadas e respeitadas". Os países devem estabelecer sistemas de informações de salvaguarda para fornecer esses dados.

Esses requisitos apresentam desafios significativos para os interessados em aplicar a REDD que precisarão interpretar as salvaguardas, determinar quais elementos coletar e como agregar essas informações de vários grupos de partes interessadas com orientação limitada da UNFCCC sobre como fazê-lo, enquanto também devem responder aos requisitos de salvaguarda dos seus acordos bilaterais e contratuais estabelecidos com os órgãos financiadores.

Muitos países ricos em florestas, a exemplo do Brasil, reconhecem essa realidade e estão começando a seguir esse caminho. Mas traduzir princípios de Direito Ambiental dos Acordos internacionais em prática é algo complexo, principalmente quando a tradição do processo legislativo nacional (STRECK, 2012), além da própria aplicação das leis ambientais,

1 (I) Ações complementares ou consistentes com os objetivos dos programas florestais nacionais e outras convenções e acordos internacionais relevantes; (II) Estruturas de governança florestais nacionais transparentes e eficazes, tendo em vista a soberania nacional e a legislação nacional; (III) Respeito pelo conhecimento e direitos dos povos indígenas e membros de comunidades locais, levando-se em consideração as obrigações internacionais relevantes, circunstâncias e leis nacionais e observando o que a Assembleia Geral da ONU adotou na Declaração das Nações Unidas sobre os Direitos dos Povos Indígenas; (IV) Participação plena e efetiva das partes interessadas, em particular povos indígenas e comunidades locais, nas ações referidas nos parágrafos 70 e 72 desta decisão; (V) Que as ações sejam consistentes com a conservação das florestas naturais e diversidade biológica, garantindo que as ações referidas no parágrafo 70 desta decisão não sejam utilizadas para a conversão de florestas naturais, mas sim para incentivar a proteção e conservação das florestas naturais e seus serviços ecossistêmicos, e para melhorar outros benefícios sociais e ambientais; (VI) Ações para tratar os riscos de reversões em resultados de REDD+; e (VII) Ações para reduzir o deslocamento de emissões de carbono para outras áreas (UNFCCC, 2015). 
esbarram em uma série de dificuldades que vão desde a ausência de discussão com a sociedade até a falta de recursos disponíveis para a execução, minando a efetividade e a eficácia (CHACÓN, 2016) das políticas ambientais.

Não obstante, o primeiro passo é entender efetivamente o que vem a ser uma salvaguarda. Para Daviet e Larsen, (2012), o termo é empregado para referir-se às políticas e procedimentos utilizados por instituições financeiras, para assegurar que os seus investimentos não causarão danos, sejam esses intencionais ou não. Essas políticas tradicionais de salvaguardas destinam-se a preencher lacunas onde as normas ou instituições nacionais não conseguem assegurar princípios de direitos humanos ou de proteção ambiental.

Por outro lado, Angelsen et al. (2012) definem as salvaguardas da REDD como um conjunto de normas e instituições que orientam expectativas em torno de resultados sociais e ambientais, associados com a redução das emissões de carbono nos países em desenvolvimento. As salvaguardas representam um compromisso para garantir que os riscos sejam minimizados ou evitados, e que os benefícios sejam alcançados.

Sem a implementação completa das salvaguardas, os riscos são potencialmente altos para as pessoas, a biodiversidade e o sucesso como um mecanismo de mitigação climática e, portanto, sua implementação plena e efetiva é tão importante quanto o próprio REDD em si mesmo (DAWSON et al., 2018). A comunicação abrangente, por meio da educação ambiental, e precisa em sua implementação é, nesse sentido, tão importante quanto o monitoramento e a emissão de relatórios sobre emissões de carbono florestal.

A transparência na implementação das salvaguardas é um fator chave em qualquer projeto REDD. Em junho de 2015, o 42 Órgão Subsidiário de Assessoramento Científico e Tecnológico (SBSTA 42) da UNFCCC decidiu que os países anfitriões da REDD devem fornecer informações sobre a implementação das salvaguardas de Cancún de forma a garantir os princípios de "transparência, consistência, abrangência e efetividade" além de reconhecer a “soberania nacional” (UNFCCC, 2015). Contudo, ainda é necessário que um instrumento prático, rigoroso e economicamente viável seja articulado.

Entender o impacto da REDD na governança, segurança da posse/propriedade do terreno, bem-estar social e outros indicadores é essencial para garantir que as políticas e programas sejam concebidos e implementados da maneira mais eficiente, efetiva e equitativa possível (DAWSON et al., 2018). Isto posto, o acompanhamento e os relatos dos países em desenvolvimento sobre as salvaguardas devem cobrir tanto as ações que geraram os resultados quanto as iniciativas que receberam financiamento proveniente de pagamentos por resultados. 
Iniciativas com a chancela da UNFCCC preveem que os países em desenvolvimento que desejam obter pagamentos por resultados da REDD devem proporcionar meios para que as salvaguardas sejam acompanhadas de duas formas, no mínimo: (i) Elaboração de um sumário de salvaguardas; e (ii) Sistema de Informações de Salvaguardas (UNFCCC, 2015). Segundo a definição do MMA (2016), o primeiro tem como objetivo oferecer informações sobre a implementação das salvaguardas de Cancún relativas ao resultado para o qual se pleiteiam pagamentos. $\mathrm{O}$ documento, apresentado periodicamente, oferece uma fotografia da implementação das salvaguardas com foco no resultado REDD, e é o requisito para acesso aos pagamentos. O segundo é um sistema, um verdadeiro repositório de dados, que no caso brasileiro se chamará SISREDD, que se encontra em fase de desenvolvimento e que deve propiciar o acompanhamento constante da implementação das salvaguardas pelo Brasil.

Cada país é obrigado a demonstrar a adequação exigida, desenvolvendo seu próprio sistema nacional de salvaguardas. A conformidade é informada por políticas, leis e regulamentos internos, e o relato ocorre por meio do que é chamado de Sistema de Informações de Salvaguardas. A própria UNFCCC não estipula qual a forma que os sistemas de salvaguarda devem tomar, apenas que as salvaguardas devem ser abordadas.

\subsubsection{REDD Brasil: Acre e Mato Grosso}

No Brasil um bom exemplo de alocação de recursos e identificação dos agentes causadores do desmatamento na REDD é o Mato Grosso. Em 2015, um processo multisetorial, liderado pelo Governo Estadual, resultou no estabelecimento de metas legais, condicionadas à conservação de áreas florestais, para aumentar a produção de soja e a produtividade da carne bovina (ANGELSEN et al., 2018; NEPSTAD et al., 2018). Isso reduziu drasticamente o desmatamento e aumentou a assistência técnica aos muitos pequenos agricultores do Estado. O Programa desenvolvido dentro da REDD, denominado Produzir, Conservar, Incluir (PCI), foi anunciado na cúpula climática de Paris, com as metas do PCI representando reduções de emissões em carbono florestal, além de reduções adicionais em metano (NEPSTAD et al., 2018).

Em decorrência desse fato, Mato Grosso recebeu um contrato de 'pagamento por desempenho' de aproximadamente US\$ 50 milhões do programa alemão REDD Early Movers (REM) e do Departamento de Negócios, Energia e Estratégia Industrial do Reino Unido, em reconhecimento ao PCI e à criação pelo Estado da Lei de REDD. As estruturas básicas para aumentar a eficiência da REDD foram: identificação dos agentes causadores e principalmente inclusão das diversas áreas receptoras no programa (ANGELSEN et al., 2018). 
De acordo com Nepstad et al. (2018), dentre as principais políticas REDD no mundo, somente Mato Grosso exibe uma ampla gama de iniciativas mais avançadas abordando a produção agrícola de grande e pequeno porte (inclusão de variedade de áreas receptoras), incluindo negociações com os principais mercados de soja e de carne (agentes causadores) para contratos de fornecimento em grande escala, alinhados com a iniciativa PCI no Estado.

No cenário nacional também merece destaque a implementação da REDD no Acre. O Estado tem políticas coerentes que se alinham com os diversos programas para todos os setores relevantes que afetam o uso da terra. Esse foco territorial facilita um alinhamento estratégico com políticas/programas públicos e significa que os governos geralmente são líderes ou participantes ativos no desenvolvimento e implementação de estratégias (PETERSEN et al., 2018).

A justificativa das referidas políticas enquanto modelos de estudo comparativo é que o Acre está mais avançado na implementação, em grande parte porque tem uma vantagem de 15 anos no desenvolvimento de uma plataforma política ('Florestania') que coloca a conservação da floresta e o apoio à subsistência sustentável em seu centro (ANGELSEN et al., 2018). A política acreana foi pioneira no Brasil em relação à REDD, sendo criada e desenvolvida contemporaneamente aos debates internacionais das COPs, obtendo, portanto, em razão do lastro temporal, uma experiência já consolidada. Ademais, inovou com a criação de um arranjo institucional único, contendo instituições públicas próprias de atuação: Comissão Estadual de Avaliação e Acompanhamento, Comitês Científicos, Ouvidorias e Agência de Desenvolvimento de Serviços Ambientais.

Em relação ao Mato Grosso, torna-se válido o estudo comparativo em razão do nível de detalhamento presente na lei matogrossense que criou um verdadeiro Sistema Estadual da REDD que trata desde a repartição dos benefícios até a elegibilidade das áreas. O Estado desenvolveu políticas e programas-chave que evoluíram para plataformas políticas e estratégias que priorizam resultados ambientais em todos os setores. Além disso, como é uma política ainda recente, se comparada à do Acre, traz um outro olhar acerca do instrumento econômico em questão. Nesse sentido, a Lei Estadual $n^{\circ}$ 9.878/13 é considerado um exemplo da "trifecta jurisdictions", parâmetro de análise de legislações REDD que reúne em uma

\footnotetext{
2 (I) REDD programs: These programs are governed at the provincial or national jurisdictional (not project) levels, focus on results-based payments for verified carbon sequestration, emphasize public policy, and address deforestation generally (not just commodity-deforestation) (UMUNAY et al., 2018).

(II) Jurisdictional approaches: JAs focus more on the role of public-private partnerships for reducing commodity-driven deforestation and avoiding economic and deforestation leakages (UMUNAY et al., 2018).
} 
mesma política (i) Programas REDD; (ii) Abordagem Jurisdicional; e (iii) Compromissos com o setor Privado (UMUNAY et al., 2018).

No plano global, esses dois programas brasileiros são considerados referências pois abordaram amplamente as causas das emissões de gases de efeito estufa em todos os setores, a diversidade de áreas receptoras e incorporaram elementos críticos como metas, tecnologias para monitorar, registrar e verificar (MRV) o carbono sequestrado e incentivos (ANGELSEN et al., 2018). A criação do "Plano Plurianual de Governança e Sustentabilidade do Acre (2016-2019) " que integrou objetivos ambientais e de desenvolvimento assim como a política do Mato Grosso “ Produzir, Conservar, Incluir (PCI) ” que está ligada à Lei Estadual da REDD, criaram estratégias coerentes para todos os principais setores econômicos (NEPSTAD et al., 2018).

\subsection{CAATINGA PERNAMBUCANA}

A Caatinga é um bioma florestal sazonalmente seco, restrito em sua maioria ao Nordeste do Brasil. Abrange $844.453 \mathrm{~km}^{2}$ (9,9\%) do território brasileiro, inserido em dez estados (Piauí, Ceará, Rio Grande do Norte, Paraíba, Pernambuco, Alagoas, Sergipe, Bahia, e Minas Gerais). Apesar de sua extensão, o conhecimento científico desse tipo de vegetação, sua biodiversidade endêmica e manejo são muito menos estudados que em outros ecossistemas brasileiros (Figura 1), como Cerrado, Mata Atlântica, Amazônia (SPECHT et al., 2019).

(III) Private sector commitments: These pledges are made in various forms - such as zero deforestation commitments and certification standards - by individual companies to reduce deforestation in their supply chains (UMUNAY et al., 2018). 
Figura 1- Ecorregiões do Brasil
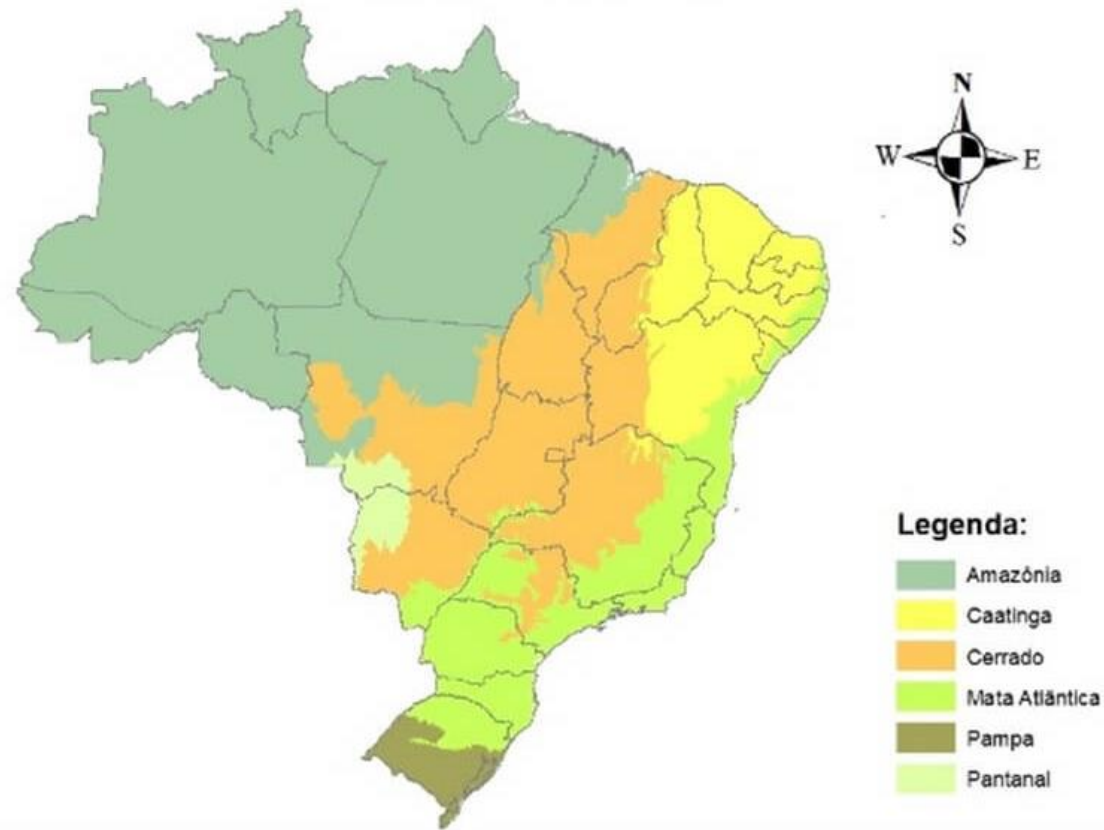

Fonte: ICMBIO (2017)

Embora a Caatinga seja a única grande região ecológica do Brasil que não é compartilhada com nenhum outro país, a importância na conservação do patrimônio natural nacional, mas também global, permaneceu amplamente ignorada pelos formuladores de políticas até o final do século passado. Somente 7,5\% da Caatinga estão dentro de áreas protegidas, sendo relativamente recente a movimentação para conservação desse bioma (MMA, 2016). Ademais, a maior parte destas áreas está em locais de formação geológica sedimentar, sendo poucas e pequenas as que estão nas áreas do embasamento cristalino, embora a Caatinga esteja predominantemente sobre esta última formação.

Criar e manter essas áreas protegidas, juntamente com mecanismo de conservação desse bioma, é importante, uma vez que quase $48 \%$ da área da Caatinga está desmatada (MMA, 2016), e acredita-se que 15\% das áreas desmatadas tenham sido desertificadas devido ao uso inadequado da terra (SILVA et al., 2018).

A região está entre os seis principais ecossistemas mundiais com a maior vulnerabilidade intrínseca à variabilidade climática (SILVA et al., 2017). A vegetação da Caatinga tem sofrido por muitas décadas devido aos impactos de perturbações agudas (isto é, perda de habitat pela produção de carvão) e perturbação antropogênica crônica (coleta de lenha e agricultura de queimada) (RIBEIRO et al., 2015). De acordo com Guanziroli et al. (2014), em toda a região semiárida, dois terços das propriedades têm menos de 10 ha e, dentre 
essas, metade tem menos de 5 ha e de todas as propriedades apenas $5 \%$ possuem mais de 100 ha.

Em Pernambuco, o bioma abrange, aproximadamente, $83 \%$ de seu território, merecendo, sem dúvida, um enfoque mais efetivo. A perda de mais de $50 \%$ de sua cobertura original (PERNAMBUCO, 2011) e o desmatamento de mais de 2.000 hectares nos últimos anos demonstram a necessidade de uma gestão mais efetiva dos recursos naturais (SILVA et al., 2018).

A Caatinga pernambucana é uma das mais fragilizadas e, ao longo da história, o uso inadequado de seus recursos naturais associado a um baixo nível de investimentos em políticas públicas sustentáveis, tornou-se bastante degradada (SPECHT et al., 2019). Essa pressão antrópica vem trazendo uma série de efeitos negativos não apenas para a vegetação, mas também para o solo, um patrimônio subestimado que é ameaçado pelo desmatamento da cobertura vegetal.

A degradação implica a perda de nutrientes e consequente redução da capacidade produtiva, além da guarida para biodiversidade (FAO, 2016). O solo é o substrato de toda a atividade rural. Por isso, o enfoque de solos (e carbono) convida a uma visão de paisagem, uma perspectiva territorial que transpõe as barreiras das práticas setoriais (apenas flora, fauna ou meio físico) (RIBEIRO et al., 2015). A boa compreensão de suas dinâmicas espaciais e temporais é fundamental para propor políticas de desenvolvimento sustentável que busquem conciliar melhorias no bem-estar humano enquanto conservam os ecossistemas naturais.

As interações entre as pessoas e a natureza na Caatinga têm sido marcadas por uma mentalidade na qual os recursos naturais são percebidos como infinitos e explorados implacavelmente devido à débil governança. De acordo com Silva et al. (2017), os impactos na região podem ser classificados em três principais grupos: (i) rápida conversão de grandes áreas de vegetação nativa em espaços criados pelo homem, como estradas, reservatórios ou agricultura comercial; (ii) o distúrbio crônico causado pela lenta, mas contínua, superexploração da vegetação nativa, como o estabelecimento de agricultura de derrubada e queima e a formação de pastos, juntamente com a coleta de lenha; (iii) os impactos negativos causados por espécies exóticas de plantas e animais que foram introduzidos na região como uma estratégia para garantir a segurança alimentar da população rural, mas que reduziram as populações de algumas espécies nativas.

A interação homem-ambiente nesse bioma remonta da colonização dos portugueses por meio do processo de interiorização através da pecuária extensiva. A Caatinga no Estado apresenta uma grande riqueza cultural devido à ocupação por diversos grupos étnicos, 
distribuídos em quase todas as regiões. De um modo geral, os grupos podem ser divididos em indígenas, quilombolas (descendentes de escravos negros trazidos da África) e comunidades rurais (SPECHT et al., 2019). Os distintos grupos exploram os recursos biológicos diferentemente em função de seus aspectos sociais, culturais, econômicos e/ou ecológicos.

Desigualdades que sempre foram elevadas aumentaram ao longo do tempo, aprofundando a lacuna social da região (Agreste e Sertão de Pernambuco). Ainda hoje, centenas têm apenas poucos hectares para produzir e prosperar, enquanto alguns controlam a maior parte da terra (GUANZIROLI et al., 2014) e outros recursos, incluindo o acesso a água potável. O contexto da Caatinga é repleto de histórias de profundas desigualdades, conflitos, competição por terra e recursos, além das lutas políticas por reconhecimento e direitos (SILVA et al., 2017).

Apesar dos problemas citados, o bioma tem um imenso potencial para a conservação de serviços ambientais, uso sustentável e bioprospecção que, se bem explorado, será decisivo para o desenvolvimento da região e do país (RIBEIRO et al., 2015). A biodiversidade ampara diversas atividades econômicas voltadas para fins agrosilvopastoris e industriais, especialmente nos ramos farmacêutico, de cosméticos, químico e de alimentos.

Ademais, o estabelecimento de pastagens e a expansão da agricultura têm sido reconhecidos por ecologistas e biólogos como perturbações que modificam a estrutura e a diversidade do ecossistema (SILVA et al., 2017). Sem dúvida, a demanda por madeira é uma das pressões na vegetação da Caatinga, apesar de atualmente estar delimitada em regiões econômicas definidas, como é o caso da área no entorno da produção gesseira. No entanto, as estratégias e decisões para a coleta de recursos são determinadas não apenas pelo ambiente, mas também por fatores socioeconômicos (NEUDERT et al., 2018).

Embora o intenso processo de degradação seja nítido devido à forte perturbação por processos históricos de ocupação e uso irracional, a vegetação da Caatinga constitui um importante recurso de subsistência para as comunidades ali residentes, que também coletam produtos necessários para manter e replicar suas práticas (SILVA et al., 2017).

Merece destaque também a prática da pecuária. $\mathrm{O}$ número de bovinos $\mathrm{e}$, especialmente, de ovinos e caprinos, tem crescido na região, e os animais tornaram-se resistentes a secas periódicas, mas quando prolongada, têm alta mortalidade, particularmente os bovinos. Do ponto de vista ecológico (SILVA et al., 2017), o setor pecuário tem sido identificado também como um fator de degradação da vegetação.

Métodos destrutivos empregados na utilização de recursos promovem o desmatamento e a degradação do bioma. À medida que um recurso se torna escasso, as pessoas o procuram 
em outras áreas, causando crescente fragmentação do habitat e convertendo as poucas manchas remanescentes de vegetação nativa em ilhas inseridas nas paisagens antropogênicas, como grandes centros urbanos ou em áreas de monoculturas (NEUDERT et al., 2018).

Essas diferenças do grau de conservação ambiental, e consequentemente potencial econômico da área, influenciam o estabelecimento e a manutenção de populações. Sem conseguir prover sua subsistência, eles ou se mudaram para as principais cidades ou permaneceram na região, tornando-se vulneráveis a todos os tipos de exploração pela elite local (SILVA et al., 2017).

De acordo com Korhonen-Kurki (2018), os países/estados com recursos florestais limitados ou que sofrem intensa pressão antrópica devem agir de maneira ativa na gestão dessas áreas. Segundo o autor, conseguindo identificar os principais fatores de degradação e iniciando as devidas mudanças de políticas, estes países/estados tendem a ser bem sucedidos no estabelecimento de programas para reduzir o desmatamento.

Pernambuco vem tentando agir dessa maneira, atualizando seu olhar em relação à Caatinga. Atualmente o bioma é o mais protegido no Estado no critério quantidades de áreas preservadas em Unidades de Conservação (SILVA et al., 2018). Todavia, conforme argumentaram SILVA et al. (2018) é fundamental identificar que essa superioridade de extensão em áreas protegidas é um fenômeno recente. Até 2012, não havia "UC de proteção integral" nesse bioma. Cabe destacar também que o recém-criado Refúgio de Vida Silvestre Tatu Bola foi implantado somente em março de 2015, sendo a maior unidade estadual de conservação de toda a região Nordeste, com 110 mil hectares (SILVA et al., 2018).

Além da Lei Estadual no 13.787/09 (Sistema Estadual de Unidades de Conservação), políticas como a Lei Estadual no 14.091/10 (Política Estadual de Combate à Desertificação e Mitigação dos Efeitos da Seca) e a Lei Estadual no 15.809/2016 (Política Estadual de Pagamentos por Serviços Ambientais), em que é prevista a REDD, são as estratégias adotados por Pernambuco para fomentar de maneira mais harmoniosa a interação homem-meio ambiente na Caatinga.

É possível observar que as principais formas degradação das florestas nos trópicos também estão presentes na Caatinga. Neudert et al. (2018), argumentando conforme Silva et al. (2017), afirmaram que as principais ações antrópicas podem ser enquadradas normalmente em categorias de impulsionadores diretos ou atividades que levam à degradação florestal: (i) extração de madeira; (ii) coleta de lenha para energia (produção de lenha e carvão vegetal); (iii) atividades pecuárias; e (iv) fogo e práticas danosas na agricultura. A identificação dos agentes causadores resulta em uma política com maior eficiência (CHACÓN, 2016). 
A Caatinga pernambucana possui uma diversidade de populações tradicionais, incluindo "sertanejos ou catingueiros", descendentes de uma mistura entre indígenas, colonizadores europeus e africanos que vivem na região há muitas gerações, adaptando-se às restrições ambientais, especialmente à irregularidade da disponibilidade de água (SPECHT et al., 2019). A maioria tem baixa renda familiar e precisa do programa de bem-estar social e renda do governo brasileiro para sobreviver, especialmente na estação seca, quando a escassez de água se exacerba e a produção de alimentos é interrompida (IBGE, 2016).

Enquanto no bioma amazônico desenvolvem-se esquemas bem-sucedidos de pagamentos por serviços ambientais (PSAs) em comunidades tradicionais vivendo dentro e fora de UCs, como o programa Bolsa Floresta financiado com recursos geridos pelo BNDES, na Caatinga essas iniciativas de conservação ainda estão ausentes, existindo apenas algumas exceções ligadas a conservação de recursos hídricos (SPECHT et al., 2019).

Dada a importância das florestas para o bem-estar, é aceito que a REDD deve minimizar os riscos para a população local (Figura 2) e produzir benefícios de subsistência para ser eficaz e equitativa. No mínimo, a REDD e outros esforços de mitigação baseados na floresta não devem prejudicar as pessoas locais, podendo ir mais longe em direção a serem favoráveis aos pobres (ANGELSEN et al., 2018).

Figura 2 - Mesorregiões de Pernambuco

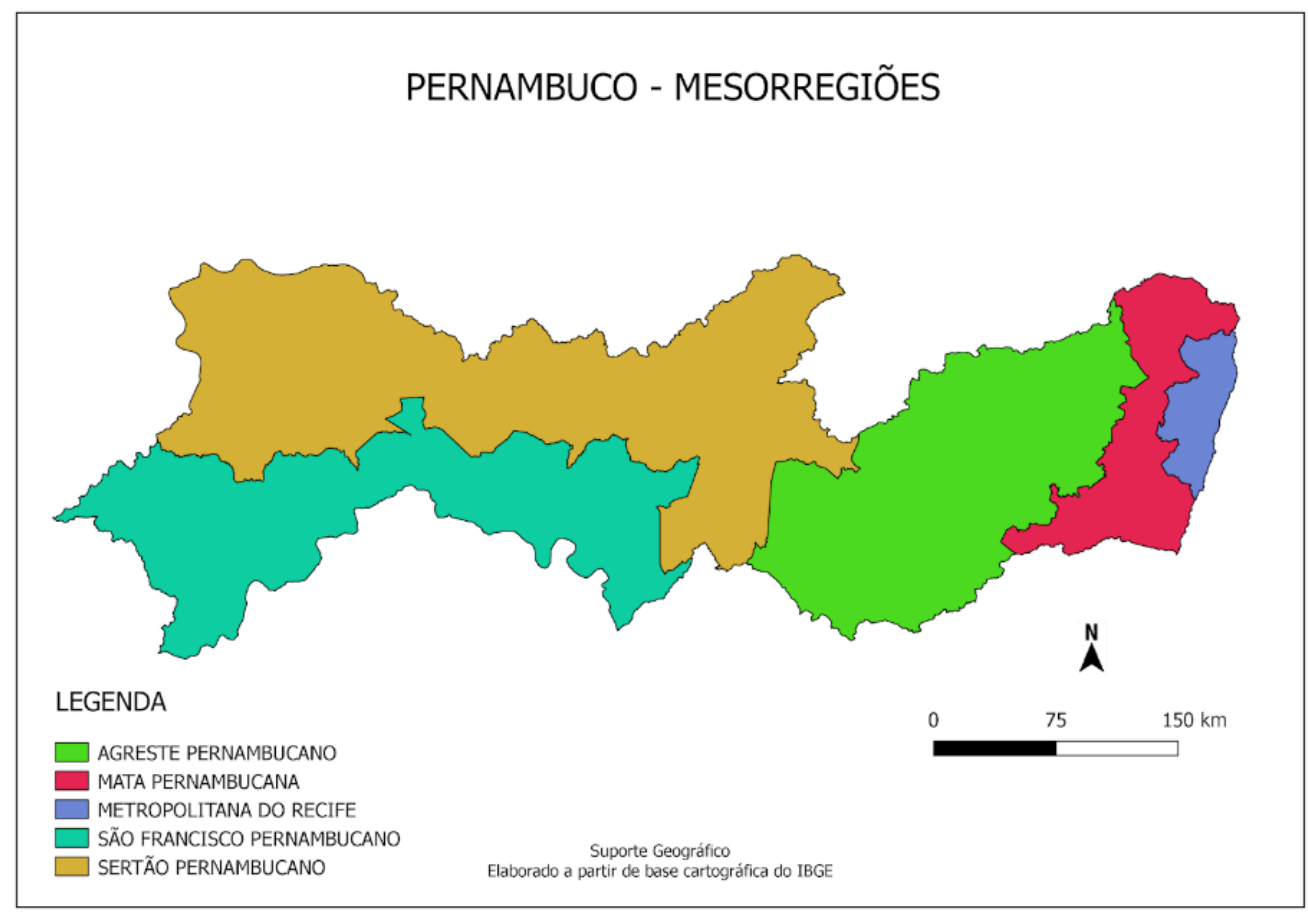

Fonte: IBGE (2010) 
A Caatinga de Pernambuco abrange as mesorregiões do São Francisco, Sertão e Agreste pernambucano (Figura 2). De acordo com o IBGE (2010), no último levantamento regional, os IDHs das respectivas regiões são 0,702; 0,663 e 0,599. Em termos populacionais, a região do São Francisco apresenta 637.626 habitantes, o Sertão 1.039 .733 e o Agreste 2.374.348 (IBGE, 2010). A pobreza continua até os dias atuais e ainda contribui para um dos mais baixos índices sociais e econômicos do país (IBGE 2016).

Mesmo diante das melhorias nos índices de qualidade de vida ao longo dos anos na região (IBGE, 2016), a Caatinga pernambucana ainda apresenta níveis inaceitáveis de pobreza, desigualdade e vulnerabilidade social como nos municípios de Manari (IDH 0,487), Jurema (IDH 0,509) e Itaíba (IDH 0,510) (IBGE, 2016). No arco do desmatamento, os municípios de pequeno e médio porte populacional estão muito longe dos centros de decisão, formando uma concentração urbana desequilibrada e com vários tipos de restrições ao desenvolvimento regional (infraestrutura, investimentos públicos e privados, capacidade de financiamento, serviços educacionais, etc.) (RIBEIRO et al., 2015).

A pobreza pode reduzir drasticamente a capacidade das famílias de investir no manejo da terra, por exemplo, limitando os aditivos, ferramentas ou a compra de irrigação para melhorar a produção de pecuária e de alimentos (NEUDERT et al., 2018; NEPSTAD et al., 2018). Famílias pobres também podem ter alta dependência de recursos naturais (ENREDD, 2016).

Práticas, como por exemplo a introdução de biogás, produzido a partir de resíduos agrícolas, esterco e outras matérias orgânicas, está ganhando popularidade em muitos países tropicais como um meio de reduzir a pressão sobre os recursos madeireiros onde a colheita de biomassa está degradando as florestas. Demonstrou-se que tais práticas reduzem a degradação, aumentando, por consequência, a regeneração da floresta (ANGELSEN et al., 2018).

A literatura recente revela que a mitigação e o sucesso da REDD na Caatinga de Pernambuco dependem de políticas que considerem as atividades econômicas (agricultura itinerante, pecuária extensiva, extração da lenha), abordagens locais e regionais, políticas ambientais integradas ao desenvolvimento econômico e participação local (SALLES et al., 2018; NEUDERT et al., 2018). Ainda, para a otimização dos resultados, governos, setor privado e a sociedade civil devem trabalhar em harmonia com as metas estabelecidas regional e localmente. A falta de coordenação entre as partes interessadas pode prejudicar a gestão sustentável dos recursos florestais e prejudicar o alcance das metas estabelecidas no contexto da REDD pelo Brasil (DAWSON et al., 2018). 
É importante estimular o envolvimento das comunidades, sociedade civil e do setor privado, promovendo diálogos que reúnam todas as partes interessadas, tendo em vista as possibilidades e os desafios do que tem sido chamado de gerenciamento florestal. O desenho e a implementação desses arranjos devem ser acompanhados de desenvolvimento sustentável local. Ao contrário, a proteção da floresta irá, necessariamente, exigir grandes esforços e uma quantia infindável de recursos financeiros. 


\section{METODOLOGIA}

Para uma melhor visualização dos processos metodológicos adotados ao longo da pesquisa a metodologia foi dividida em três partes de acordo com cada objetivo específico: Caracterização dos aspectos legais; Análise das características da implementação da REDD e Análise das salvaguardas propostas na PEPSA.

\subsection{CARACTERIZAÇÃO DOS ASPECTOS LEGAIS}

Em relação ao primeiro objetivo específico (I) foi feita uma análise dos diplomas legais que podem ser utilizados como base para a implantação da REDD em Pernambuco. As principais fontes de consulta foram às regulamentações, tanto nacionais quanto estaduais. No âmbito nacional, foram as publicações oficiais provenientes do Ministério do Meio Ambiente (MMA) e do Ministério de Ciência, Tecnologia e Inovação do Brasil (MCTI). No estadual foram a Lei Estadual $n^{\circ}$ 14.090/10 (Política Estadual de Enfrentamento das Mudanças Climáticas) juntamente com seu plano e a Lei Estadual n ${ }^{\circ}$ 15.809/16 (Política Estadual de Pagamento por Serviços Ambientais).

Buscou-se enfatizar os principais aspectos que favorecem, ou ao menos possibilitam, a concretização do instrumento no aspecto político-legal. Cabe a advertência que não se pretende exaurir a análise das legislações em todos em seus aspectos, mas somente naquilo que pode ser utilizado como fundamentação para instauração da REDD.

A avaliação da Política Estadual de Enfrentamento às Mudanças Climáticas de Pernambuco foi iniciada com a análise do texto da norma. Por meio dessa busca-se vislumbrar a existência de um balanço entre as ações de adaptação e mitigação às mudanças climáticas. Para tanto foram explorados desde os princípios que norteiam a política até os objetivos que se buscam, perpassando pelos instrumentos estabelecidos para alcança-los. Esses elementos foram confrontados com o que se observa das ações previstas e realizadas pelo poder público, para avaliar se os princípios e objetivos condizem com o realizado, e desta forma analisar se a política está servindo como um guia para as ações públicas.

Em relação à Política Estadual de Pagamento por Serviços Ambientais (PEPSA) foram identificados seus objetivos assim como o arranjo institucional criado pela lei, os instrumentos propostos e as áreas suscetíveis (requisitos) de receber projetos de PSA Carbono. Cabe acentuar que como o enfoque da pesquisa é em relação ao REDD, somente foram examinados os tópicos que possuem relação com essa temática, deixando para o futuro o estudo da íntegra da Política. 


\subsection{ANÁLISE DAS CARACTERÍSTICAS DA IMPLEMENTAÇÃO DA REDD}

No que cabe ao segundo objetivo, os atributos analisados da PEPSA foram: financiamento, áreas receptoras e beneficiários. A definição dos referidos campos da atuação da REDD deu-se em razão da sua importância para construção de qualquer iniciativa desse modelo (UMUNAY et al., 2018). Da mesma maneira, cada um é permeável, sendo influenciado e influenciando o outro.

O fundamento para utilização dos fatores é a necessidade de ter claras a natureza e a origem dos recursos para implementação dos projetos (Como?), da mesma forma quais espaços poderão ser elegíveis para receber os investimentos (Onde?) e, igualmente, quem poderá ser beneficiado com essa iniciativa (Quem?) (LIBERT AMICO; TRENCH, 2016). Para tanto, na presente pesquisa, foram selecionadas duas políticas estaduais brasileiras que abordam a REDD e estão em vigor, a do Acre (Lei Estadual no 2.308/10) e a do Mato Grosso (Lei Estadual nº 9.878/13).

Para ter um parâmetro comparativo com outros sistemas em vigor no território nacional foi feito um balanço da previsão legal dos três atributos basilares para a criação de projetos REDD. Utilizou-se o método comparativo que consiste na confrontação de dois ou mais objetos jurídicos de ordenamentos e/ou sistemas distintos, tanto nacionais como internacionais. Esses objetos podem referir-se a princípios, institutos específicos (como o licenciamento ambiental, o tombamento ou a REDD) e a sistemas completos (Política Nacional de Mudanças Climáticas ou Sistema Nacional de Unidades de Conservação) (DUTRA, 2016).

Para exame do parâmetro "financiamento" foram consultadas publicações de órgãos fomentadores como o Climate Funds, UN-REDD e o Banco Nacional de Desenvolvimento (BNDES) além dos documentos oficiais do Ministério do Meio Ambiente e da Organização das Nações Unidas, bem como as Leis Estaduais de Pernambuco, Acre e Mato Grosso. Outrossim, também serviram como alicerce para a análise artigos nacionais e internacionais sobre a temática.

No que cabe a identificação das "áreas receptoras" potenciais na Caatinga pernambucana foi seguido o disposto na Lei Estadual $n^{\circ} 15.809 / 2016$, Art. 14, $\S 4^{\circ}$ em que apenas são elegíveis: (I) Reserva Particular de Patrimônio Natural (RPPN), (II) Áreas de Preservação Permanente (APP) e Reserva Legal (RL) excedentes e (III) servidões florestais. 
A RPPN é uma área privada, gravada com perpetuidade, com o objetivo de conservar a diversidade biológica inclusa no rol das unidades de conservação, do grupo uso sustentável, prevista na Lei Federal nº 9.985/00 (MILARÉ, 2013). No tocante as APP, essas possuem base legal na Lei Federal no 12.651/12 e são áreas protegidas, coberta ou não por vegetação nativa, com a função ambiental de preservar os recursos hídricos, a paisagem, a estabilidade geológica e a biodiversidade entre outras funções ambientais (SIRVINSKAS, 2017). No que cabe à RL, que também tem base legal na Lei Federal no 12.651/12, é uma área localizada no interior de uma propriedade ou posse rural com a função de assegurar o uso econômico de modo sustentável dos recursos naturais do imóvel rural, auxiliar a conservação e a reabilitação dos processos ecológicos (MILARÉ, 2013). A última área receptora considerada pela PEPSA é a servidão florestal, também denominada de servidão ambiental, prevista na Lei Federal $\mathrm{n}^{\circ}$ 12.651/12, que consiste na instituição por particular da limitação do uso de toda a sua propriedade ou de parte dela para preservar, conservar ou recuperar os recursos ambientais existentes (SIRVINSKAS, 2017)

Cabe a ressalva que para este estudo apenas foram consideradas as áreas de RPPNs pois a obtenção dos dados referentes às áreas II e III não foi possível em razão da não disponibilização dessas informações tanto nos sistemas públicos de informações (Sistema Nacional de Cadastro Rural (SISCAR) e Sistema de Informações Geográficas Caburé (SIG CABURÉ-Pernambuco)) quanto pela ausência de maneira informatizada desses dados (as áreas de servidão florestal são registradas nos cartório de imóveis de cada município, assim como os excedentes de Reserva Legal). Contudo a ausência de tais informações não macula o principal enfoque do presente estudo que é evidenciar características (financiamento, áreas e beneficiários) da REDD na Caatinga pernambucana.

Ademais, cabe enfatizar que Pernambuco ainda não concretizou o disposto na PEPSA que é a efetivação do Cadastro Estadual de Áreas Prioritárias para Pagamentos por Serviços Ambientais - CEAP-PSA que deveria estar finalizado no ano de 2017 (PERNAMBUCO, 2016).

Para sistematizar os resultados obtidos em relação as áreas, foi elaborado um mapa por meio do software Quantum Giz com base em shapes fornecidos pelo Instituto Chico Mendes de Biodiversidade (ICMBIO), Instituto Brasileiro de Geografia e Estatística (IBGE) e o Instituto Nacional de Colonização e Reforma Agrária (INCRA), com informações datadas, respectivamente de 2017, 2010, 2016. As informações obtidas tiveram como intuito enfatizar as unidades de conservação no Estado, os assentamentos rurais federais e delimitação de bioma Caatinga em Pernambuco. A inclusão dos assentamentos rurais deve-se ao seu 
subaproveitamento na PEPSA, fator esse que fica evidenciado nos resultados obtidos. Além desses, de maneira suplementar, foram consultados dados de publicações oficiais do Ministério do Meio Ambiente (MMA), da CPRH -Agência Estadual de Meio Ambiente de Pernambuco e do SISCAR.

Por fim, no que cabe ao parâmetro "beneficiários" foi feita a caracterização da população residente na Caatinga, levando em consideração a divisão de Pernambuco em Mesorregiões (Mesorregião do São Francisco, Mesorregião do Sertão, Mesorregião do Agreste). Além desse exame, realizou-se um estudo sobre a propriedade do carbono e suas implicações aos beneficiários da REDD tomando como base a literatura especializada.

Ao fim da análise foi feito um quadro comparativo contendo as principais características dos três modelos (Pernambuco, Acre e Mato Grosso) de política REDD baseados no financiamento, áreas receptoras e beneficiários.

\subsection{ANÁLISE DAS SALVAGUARDAS PROPOSTAS NA PEPSA}

Em relação ao terceiro objetivo específico, a metodologia usada como base para análise das disposições propostas na Lei Estadual $n^{\circ}$ 15.809/2016 é a REDD Safeguard Spectrum Framework (RSS Framework), desenvolvida por Arhin (2014), em que cada salvaguarda é incorporada em um grupo de acordo com os seus objetivos propostos, conforme a Figura 3. Cabe destacar que a classificação composta originalmente por Arhin (2014) apresenta-se, nessa ordem: preventive safeguards; mitigative safeguards; promotive safeguards; and transformational safeguards. No entanto, no presente trabalho, foram adotados apenas as três primeiras. A justificativa para tal escolha metodológica deve-se à particularidade da legislação ambiental brasileira, e por consequência de Pernambuco, em razão da primazia aos princípios interpretativos.

O outro argumento que sustenta a não utilização integral da classificação original é a proximidade conceitual entre as promotive safeguards e as transformational safeguards, já admitida pelo próprio autor. Apesar dos argumentos válidos de Arhin (2014), que residem principalmente na profundidade das modificações propostas pelas salvaguardas transformativas focadas de maneiras explícitas na participação popular, esta pesquisa, baseada em autores como Sarlet (2007) e Streck (2012), adotou a classificação de salvaguardas principiológicas para evidenciar um perigo existente em diversas normativas ambientais internacionais e principalmente brasileiras. 
Figura 3 - Espectro de salvaguardas da REDD

\begin{tabular}{|c|c|c|c|c|}
\hline Enquadramento & $\begin{array}{l}\text { Salvaguardas } \\
\text { Principiológicas }\end{array}$ & $\begin{array}{c}\text { Salvaguardas } \\
\text { Preventivas }\end{array}$ & $\begin{array}{c}\text { Salvaguardas } \\
\text { Mitigativas }\end{array}$ & $\begin{array}{c}\text { Salvaguardas } \\
\text { Impulsoras }\end{array}$ \\
\hline Objetivo Principal & $\begin{array}{c}\text { Buscar mudanças de } \\
\text { paradigmas nas } \\
\text { estruturase marcos } \\
\text { legais. Sấo princípios } \\
\text { gerais norteadores das } \\
\text { açốes. São } \\
\text { verdadeiras teses } \\
\text { programátioas. }\end{array}$ & $\begin{array}{c}\text { Prevenir pessoase } \\
\text { comunidades de } \\
\text { sofrerem danos } \\
\text { significativos em seus } \\
\text { meios de subsistência } \\
\text { devido às estratégias } \\
\text { adotadas para a Redd }\end{array}$ & $\begin{array}{l}\text { Mitigar os impactos } \\
\text { negativos da Redd } \\
\text { nas comunidades } \\
\text { locais e nos seus } \\
\text { meios de subsistência }\end{array}$ & $\begin{array}{c}\text { Promoverimelhorar } \\
\text { oportunidades para as } \\
\text { comunidades, } \\
\text { potencializando suas } \\
\text { práticas e os benefícios } \\
\text { ligados à Redd }\end{array}$ \\
\hline Como & $\begin{array}{c}\text { Definiçấo de objetivos } \\
\text { para conduzir a } \\
\text { implementação } \\
\text { gestão da Redd. }\end{array}$ & $\begin{array}{c}\text { Evitando } \\
\text { estratégiasłabordagens } \\
\text { com privaçốes abusivas } \\
\text { para implantaçấo da } \\
\text { Redd }\end{array}$ & $\begin{array}{c}\text { Ámenização dos } \\
\text { impactose das } \\
\text { consequências } \\
\text { negativas uma vez } \\
\text { ocorridos }\end{array}$ & $\begin{array}{l}\text { Afirmação dos direitose } \\
\text { responsabilidades, em } \\
\text { vez de fazer mudanças } \\
\text { no regime sociopolítico } \\
\text { e normativo: } \\
\text { Implementação de } \\
\text { sistemas de } \\
\text { informaçôes sobre as } \\
\text { salvaguardas }\end{array}$ \\
\hline Exemplos & $\begin{array}{c}\text { Reduçấo da pobreza; } \\
\text { aumento da qualidade } \\
\text { de vida; Respeito aos } \\
\text { princípios da ONU. }\end{array}$ & $\begin{array}{l}\text { Evitar o despejo } \\
\text { forçado, a expulsấo das } \\
\text { terras, o deslocamento } \\
\text { e a exclusão de } \\
\text { comunidades locais do } \\
\text { uso de recursos, como } \\
\text { produtos florestais nấo- } \\
\text { madeireiros. }\end{array}$ & $\begin{array}{l}\text { Reassentamento de } \\
\text { comunidades } \\
\text { deslocadas: } \\
\text { compensaçấo às } \\
\text { comunidadese } \\
\text { individuos afetados: } \\
\text { garantia aos direitos } \\
\text { de uso dos produtos } \\
\text { nâo madeireiros. }\end{array}$ & $\begin{array}{l}\text { Incremento da } \\
\text { participaçấo na } \\
\text { elaboraçấo de } \\
\text { políticas; fomentar a } \\
\text { responsabilidade e } \\
\text { transparência no } \\
\text { manejo florestal; } \\
\text { incentivar prátioas que } \\
\text { aumentem a difusấo de } \\
\text { informaçốes. }\end{array}$ \\
\hline
\end{tabular}

Aumento da proteção e dos benefícios para as comunidades locais

Fonte: Elaborado pelo autor, baseado em Arhin (2014).

A criação dessa categoria tem como fundamento trazer à tona o uso em excesso de princípios na elaboração e aplicação das leis ambientais, gerando o denominado panprincipiologismo (STRECK, 2012). A utilização em excesso do referido instrumento hermenêutico pode causar situações como a dificuldade de implementação do comando normativo no caso concreto e o perigo de abstração excessiva na interpretação da aplicação, trazendo como consequência a falta de efetividade (CHACÓN, 2016).

Outra modificação realizada no RSS Framework original foi o reposicionamento das classes no espectro. Nesta, a classificação era disposta da seguinte maneira: preventive safeguards, mitigative safeguards, promotive safeguards and transformational safeguards. A desenvolvida para essa pesquisa pode ser visualizada na Figura 3. O motivo para tal alteração deve-se ao próprio contexto normativo da legislação ambiental do Brasil na qual existe uma grande primazia pelos princípios em detrimento de disposições concretas para aplicação. 
Baseado nessa justificativa, no espectro proposto, as salvaguardas mais à esquerda (ou seja, propiciam um menor aumento da proteção e benefícios da comunidade local) são as principiológicas e as mais à direita (que propiciam um maior aumento da proteção e benefícios da comunidade local) são as salvaguardas impulsoras.

Postas essas ressalvas, cabe conceituar cada categoria adotada de maneira mais analítica. As salvaguardas preventivas são aqueles critérios e proposições que buscam "não gerar dano" às comunidades locais. O objetivo principal, definido de maneira explícita ou não, é prevenir ou evitar a privação significativa como resultado da implementação da REDD (ARHIN, 2014). Exemplos de salvaguardas preventivas incluem o planejamento de estratégias específicas para REDD, evitando consequências como a ocupação indireta, a desapropriação, a falta de terras (MATHEUS, 2018), o deslocamento e a exclusão de comunidades locais do uso de recursos (MBATU, 2016). Salvaguardas preventivas são os requisitos mínimos para estratégias de REDD.

As salvaguardas mitigativas são as iniciativas que buscam minimizar o impacto negativo da REDD sobre as comunidades locais e seus meios de subsistência (ARHIN, 2014). Enquanto as medidas preventivas reduzem a probabilidade de ocorrência do risco, as salvaguardas mitigativas reduzem o impacto se o risco ocorrer, como por exemplo o reassentamento de comunidades deslocadas, a compensação financeira de indivíduos afetados e a concessão de direitos para uso do espaço (NEUDERT, 2018), a exemplo do arrendamento e do usufruto.

Por fim, as salvaguardas impulsoras são aquelas cuja ênfase é amplamente voltada para a promoção ou melhoria de oportunidades, bem como espaços para as pessoas e comunidades florestais contribuírem para a tomada de decisões, melhorarem sua subsistência e beneficiarem-se do esquema REDD. São consideradas catalizadoras dos benefícios alcançados. Exemplos podem incluir a promoção da participação de comunidades na formulação de políticas (ARHIN, 2014), o desenvolvimento de responsabilidade e transparência no manejo florestal, a instituição de práticas que aumentem a difusão de informações e a disponibilidade de assistência técnica para extensão rural (PAMELA; PUSHPENDRA, 2017).

Cabe destacar que uma mesma salvaguarda pode apresentar características diferentes; ocorrendo tal hipótese, esta pode ser denominada salvaguarda mista ou híbrida. Por exemplo, é plenamente possível ter uma salvaguarda com traços das classes mitigativo e impulsora. Via de regra isso acontece na construção do texto no documento normativo e pode sim ser considerado um obstáculo para implementação da salvaguarda tendo em vista que ao invés de 
medir sua efetividade pela consecução de um objetivo (mitigativo ou impulsora por exemplo), será necessário a obtenção nas duas frentes de atuação. Destarte, para fins tanto de construção, análise ou implementação, o ideal é que as salvaguardas possuam traços preponderantes em uma das classes sugeridas.

Para classificação das dez (10) salvaguardas previstas na PEPSA foi utilizada como base a revisão bibliográfica feita em periódicos, normas internacionais (Acordos, Tratados), legislação ambiental brasileira e guias de implementação de salvaguardas da ONU e do Banco Mundial. Com base na verificação, foi feito um quadro esquemático com a classificação das salvaguardas em que as linhas são as salvaguardas da PEPSA e as colunas a classificação proposta. 


\section{RESULTADOS E DISCUSSÃO}

Nesse tópico serão discutidos as principais leis ambientais que fundamentam a REDD em Pernambuco, juntamente com as salvaguardas, bem como as características de implementação da REDD, ressaltando principalmente o financiamento, as áreas receptoras e os beneficiários.

\subsection{PARÂMETROS LEGAIS DA REDD EM PERNAMBUCO}

A Política Estadual de Enfrentamento às Mudanças Climáticas (Lei Estadual $\mathrm{n}^{\circ}$ 14.090/10) traz em seu escopo a apresentação padrão para as normativas ambientais brasileiras: conceitos, objetivos e instrumentos. Tal formatação, de acordo com Milaré (2013) visa facilitar o acesso pela população em geral ao conteúdo da norma. Além desses, apresenta também o capítulo denominado "Estratégias de mitigação e adaptação", buscando com isso pormenorizar os campos de atuação da legislação.

Não obstante o caráter pedagógico apresentada pela lei, o seu conteúdo, logo na apresentação conceitual, presente no art. $1^{\circ}$ e incisos, demonstra sua atualidade perante os principais acordos e convenções concernentes às alterações climáticas. Expressões como MDL (Mecanismo de Desenvolvimento Limpo), REDD e mercado de carbono estão presentes. O objetivo geral é apresentado da seguinte maneira:

\footnotetext{
Art. $2^{\circ}$ A Política Estadual de Enfrentamento as Mudanças do Clima tem por objetivo garantir à população que o Poder Público promova os esforços necessários para aumentar a resiliência da população pernambucana à variabilidade e às mudanças climáticas em curso; bem como contribuir com a redução das concentrações dos gases de efeito estufa na atmosfera, em níveis não danosos às populações e aos ecossistemas, assegurando o desenvolvimento sustentável. (PERNAMBUCO, 2010).
}

$\mathrm{Na}$ leitura inicial do caput percebe-se que o Poder Público traz para si a responsabilidade para a implementação da Política Estadual. De acordo com Fiorillo (2014), tal postura, em matéria ambiental, não é a mais adequada a ser adotada. $\mathrm{O}$ autor argumentou que a responsabilidade deve ser dividida perante a sociedade e a iniciativa privada, além do Poder Público, na medida das possibilidades institucionais e legais. Para tanto, traz como exemplo o texto da Constituição Federal de 1988, no seu Art. 225, em que fica clara a intenção do legislador constituinte da incumbência imposta ao Poder Público e à coletividade o dever de defender e preservar o ambiente para as presentes e futuras gerações (BRASIL, 1988).

É vital destacar que, assumindo uma interpretação conforme à Constituição, o objetivo geral da lei pernambucana não exime a coletividade e as empresas de assumirem a postura em 
favor da natureza que se refere às mudanças climáticas. Sem dúvida que se perde a oportunidade de concretizar de maneira expressa tal relação. Ost (2015) aduziu que além de um impacto moral e político, a corporificação legal das temáticas ambientais, e nesse caso das alterações climáticas, abre uma gama de benefícios de diversas ordens, propiciando um embate na (re)organização do relacionamento da sociedade e do Poder Público.

De maneira congruente com seu aspecto material exposto nos primeiros artigos, os objetivos específicos revelam-se plenamente voltados para o enfoque econômico do meio ambiente. Preceitos como "I - criar instrumentos econômicos, financeiros e fiscais, para a promoção dos objetivos, diretrizes, ações e programas previstos nesta Lei”, "II - fomentar a criação de instrumentos de mercado para a mitigação das emissões de GEE ", "XIV promover padrões sustentáveis para atividades agropecuárias à luz das considerações sobre a mudança do clima" e "XVI - promover um sistema de pagamentos por serviços ambientais" mostram a presença de objetivos estritamente ligadas à uma visão baseada no princípio do protetor-recebedor descrito por Sirvinskas (2017).

As estratégias adotadas pela Política são reveladas de acordo com os setores econômicos da atividade, divididos em quatorze seções ${ }^{3}$. Os mecanismos previstos impõem ao Governo Estadual desde ações ligadas à educação ambiental voltada para a coletividade até a investigação e o monitoramento dos fatores de risco à vida e à saúde decorrente da mudança do clima. Outrossim, as estratégias mencionadas na norma incorporam o ideal do Poder Público como o principal agente responsável pela efetividade das ações, deixando a coletividade e o setor privado como meros receptores de comandos advindos do poder emanado pela Administração.

No capítulo referente aos instrumentos, eles são divididos por tipologia ${ }^{4}$. Diferentemente do que ocorre em outras leis ambientais, como a Política Nacional do Meio Ambiente (Lei Federal n ${ }^{\circ}$ 6.938/81), o capítulo não traz apenas instrumentos pontuais (Licenciamento Ambiental, Avaliação de Impactos Ambientais) mas sim verdadeiras diretrizes de efetivação dos objetivos específicos previstos anteriormente.

\footnotetext{
${ }^{3} 1$ - Energia; 2 - Transporte; 3 - Industrial e Mineração; 4 - Setor Público; 5 - Agropecuária; 6 - Biodiversidade e Florestas; 7 - Recursos Hídricos; 8 - Resíduos e Consumo; 9 - Construção Civil; 10 - Saúde; 11-Oceano e Gestão Costeira; 12 - Semiárido e Desertificação; 13 - Uso do solo e cobertura vegetal urbana; e 14 - Instrumentos de Comando e Controle

41 - Plano Estadual de Mudanças Climáticas; 2 - Instrumentos de Informação e Gestão; 3 - Instrumentos Econômicos e Fiscais; 4 - Projetos de Mitigação de Emissões de Gases de Efeito Estufa; 5 - Licitações Sustentáveis; 6 - Educação, Pesquisa, Comunicação e Disseminação; 7 - Defesa Civil; e 8 - Recursos Financeiros para Ações de Enfrentamento às Mudanças Climáticas e Serviços Ambientais)
} 
Em razão da proposta inicial da presente pesquisa, o foco será dado no instrumento que define um verdadeiro organograma de implementação da política como um todo, "visando fundamentar e orientar a implantação da PEEMC de longo prazo, com horizonte de planejamento compatível com o período de implantação de seus programas e projetos" (PERNAMBUCO, 2010).

O Plano Estadual de Mudanças Climáticas possui três linhas básicas de metas a serem alcançadas no decorrer de seis anos a partir da sua promulgação: metas obrigatórias, metas gerais e metas setoriais. As metas obrigatórias estão previstas no art. 23 da PEEMC. Possuem essa denominação pois fundamentam e orientam a implantação da política; basicamente são as estruturas basilares que têm como escopo alicerçar o substrato básico do diploma legal. São consideradas o conteúdo infinitesimal a ser efetivado, a essência da concretização da política (PERNAMBUCO, 2011).

Dentre as metas obrigatórias, no total de nove, merecem destaque quatro em razão do seu potencial de ação: o diagnóstico da situação atual das mudanças climáticas no Estado, contendo o mapeamento das vulnerabilidades e suscetibilidades aos impactos esperados; o inventário da contribuição do Estado para a emissão brasileira dos gases de efeito estufa; o zoneamento socioeconômico e ecológico de risco climático; e o estabelecimento das diretrizes e critérios para os Projetos de Redução de Emissões pelo Desmatamento e Degradação Florestal.

As metas gerais também foram concebidas através da definição dos seus componentes, eixos temáticos e áreas de atuação, buscando determinar ações para a implementação da PEEMC de forma conectada com as demais políticas públicas ambientais de Pernambuco. A função dessas metas é propiciar uma conexão com outras políticas que tangenciem a problemática do clima de modo a desenvolver ações integradas. Em relação aos componentes (Figura 4) eles se dividem em dois: adaptação e mitigação.

De acordo com a PEEMC, no seu art.1 $1^{\circ}$, I considera-se adaptação "conjunto de iniciativas e estratégias que permitem a adaptação, nos sistemas naturais ou criados pelos homens, a um novo ambiente, em resposta à mudança do clima atual ou esperada" (PERNAMBUCO, 2010). Já mitigação, para efeitos da política estadual, no art. $1^{\circ}$, inciso X, considera-se a "ação humana para reduzir as emissões por fontes ou ampliar os sumidouros de gases de efeito estufa" (PERNAMBUCO, 2010). 
Figura 4 - Componentes, eixos e áreas de atuação do Plano Estadual do Clima

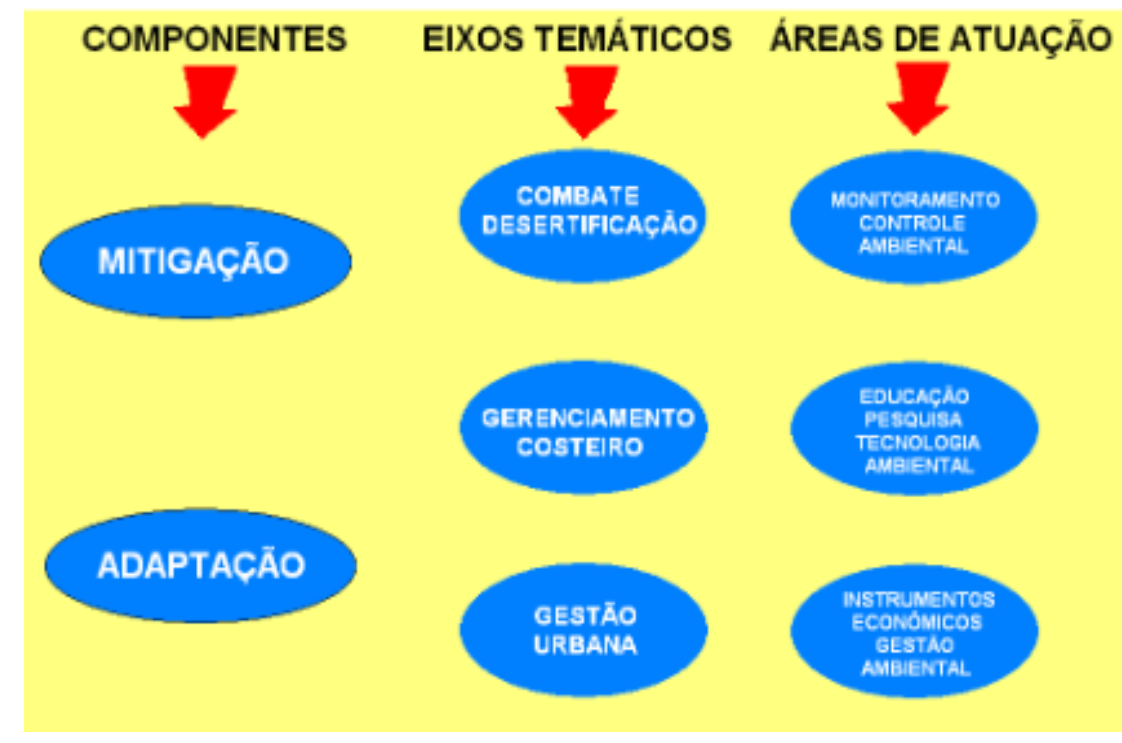

Fonte: Elaborado pelo autor.

Os eixos temáticos propostos dividem-se em três: combate à desertificação; gerenciamento costeiro; e gestão urbana. Por fim, em relação à área de atuação, que pode ser entendida como os meios pelo quais se pretendem instrumentalizar os objetivos propostas, são sistematizados em três grupos: monitoramento/controle ambiental; educação, pesquisa e tecnologia ambiental; e instrumentos econômicos/gestão ambiental. Nessa divisão fica claro os enfoques dados pelo Governo Estadual. No primeiro momento (monitoramento/controle ambiental) têm-se os instrumentos diretamente ligados ao poder de polícia ambiental estatal que consiste na faculdade de que dispõe a Administração Pública para condicionar e restringir o uso e gozo de bens, atividades e direitos individuais, em benefício da coletividade ou do próprio Estado (MILARÉ, 2013)

A área de atuação denominada "educação, pesquisa e tecnologia ambiental” integra a necessidade de programas e ações voltadas ao desenvolvimento de iniciativas no campo do desenvolvimento tecnológico acerca de medidas que possam subsidiar a implementação da própria política. Nesse caso, de maneira clara, o Poder Público admite a necessidade de constante atualização e necessidade de integração entre os diversos atores envolvidos no avanço da política (Figura 5). 
Figura 5 - Recorte do cronograma previsto no Plano e diversidade de atores envolvidos na implementação das metas

\begin{tabular}{|c|c|c|c|c|c|c|c|}
\hline \multicolumn{2}{|l|}{ ADAPTACCÃO: METAS MINIMAS PREVISTAS EM LEI ESTADUAL } & \multicolumn{6}{|c|}{ Anos } \\
\hline Atividades & Agentes Envolvidos & I & II & III & IV & V & VI \\
\hline $\begin{array}{l}\text { Revisão do Zoneamento Ecológico Económico Costeiro -ZEEC - de } \\
\text { Pernambuco, incluindo os novos condicionantes decorrentes das Mudanças } \\
\text { Climáticas }\end{array}$ & $\begin{array}{l}\text { SEMAS, Prefeituras dos } \\
\text { Municípios Litorâneos, } \\
\text { Universidades, ONG'S }\end{array}$ & & & & & & \\
\hline $\begin{array}{l}\text { Elaborar o Zoneamento Ecológico Económico do semi-árido de Pernambuco, } \\
\text { incluindo as questôes decorrentes dos efeitos das Mudanças Climáticas }\end{array}$ & $\begin{array}{l}\text { SEMAS, EMBRAPA, } \\
\text { CONDEPE/FIDEM, } \\
\text { Universidades, ONG'S }\end{array}$ & & & & & & \\
\hline $\begin{array}{l}\text { Diagnóstico dos sistemas naturais das bacias hidrográficas de Pernambuco, } \\
\text { identificando as potencialidades e disponibilidades hídricas das bacias e sua } \\
\text { evoluçäo face aos cenários de aquecimento para os anos de 2020,2030, } 2040 \\
\text { e } 2050 \text {. }\end{array}$ & $\begin{array}{l}\text { SEMAS, SRHE, CPRH, } \\
\text { Compesa, APAC, ANA, } \\
\text { CODEVASF, Universidades, } \\
\text { ONG'S }\end{array}$ & & & & & & \\
\hline $\begin{array}{l}\text { Identificação e Diagnóstico das áreas críticas de desertificação no território de } \\
\text { Pernambuco }\end{array}$ & $\begin{array}{l}\text { SEMAS, EMBRAPA, } \\
\text { Universidades, ONG'S }\end{array}$ & & & & & & \\
\hline $\begin{array}{l}\text { Elaboração do Mapa de Vulnerabilidade Ambiental do semi-árido de } \\
\text { Pernambuco }\end{array}$ & $\begin{array}{l}\text { SEMAS, EMBRAPA, } \\
\text { CONDEPE/FIDEM, } \\
\text { Universidades, ONG'S }\end{array}$ & & & & & & \\
\hline $\begin{array}{l}\text { Elaboração dos Mapas de Vulnerabilidade Ambiental dos municípios litorâneos } \\
\text { de Pernambuco }\end{array}$ & $\begin{array}{l}\text { SEMAS, Prefeituras dos } \\
\text { Municípios Litorâneos, } \\
\text { Universidades, ONG'S }\end{array}$ & & & & & & \\
\hline
\end{tabular}

Fonte: Adaptado pelo autor (PERNAMBUCO, 2011).

Resgatando a postura adotada ao longo da PEEMC e do próprio plano, os instrumentos econômicos/gestão ambiental demonstram a tendência, positiva e contemporânea, de minimizar os problemas ligados ao meio ambiente, conjugando uma presença tanto nas ferramentas de comando e controle quanto nos de incentivo positivo, utilizando para isso mecanismos como a tributação ambiental e o pagamento por serviços ambientais, dentre outros (REIS NETO et al., 2016).

Por fim, as metas setoriais nada mais são do que uma listagem do que se pretende implementar em diversos setores da sociedade que estão presentes na PEEMC no capítulo referente às estratégias, como por exemplo setor de energia, setor de transporte, setor de biodiversidade e florestas.

No mais, o plano estabelece de uma forma geral conceitos muito abstratos e basicamente um cronograma das atividades relacionadas à política estadual. Não preza por uma facticidade. Quando traçadas, as metas não revelam como serão alcançadas. Apesar de tais situações que dificultam a aplicação do plano, este cumpre com o seu objetivo principal que é demonstrar quando será feita, teoricamente, cada etapa da Política Estadual.

Conforme o avanço da temática e a difusão de práticas que contribuem para a aplicação de conhecimentos ligados aos PSAs, Pernambuco, por meio de seu órgão central do Sistema Estadual de Meio Ambiente (SISEMA) qual seja a Secretaria de Meio Ambiente (SEMAR), elaborou, com o objetivo de padronização das práticas/programas que possuem como fundamento o PSA, a Lei Estadual n 15.809/16, também denominada Política Estadual de Pagamentos por Serviços Ambientais (PEPSA). A principal função desta lei é tentar 
conferir e fomentar, com o mínimo de base legal para o Estado e para os particulares envolvidos, a utilização do PSA como ferramenta de proteção ambiental. Não obstante tal objetivo mais genérico, logo no Art. $2^{\circ}$, a norma traz os seguintes objetivos específicos:

Art. $2^{\circ}(\ldots)$ :

I - incentivar o mercado de serviços ambientais e reconhecer a sua valoração econômica e social;

II - incentivar a recuperação, a manutenção e a melhoria das condições de equilíbrio ecológico das áreas especialmente protegidas, em especial das áreas de reserva legal, de preservação permanente, das unidades de conservação, das áreas suscetíveis à desertificação, das áreas estuarinas, das zonas de recarga de aquífero e/ou de abastecimento de mananciais;

III - preservar, recuperar e/ou conservar o patrimônio ambiental do Estado de Pernambuco para viabilizar a prestação de serviços ambientais pelos ecossistemas locais, observando-se as especificidades dos biomas Caatinga e Mata Atlântica com seus ecossistemas associados;

IV - promover projetos de Pagamento de Serviços Ambientais - PSA que beneficiem povos e comunidades tradicionais, definidos na forma do Decreto Federal $n^{\circ}$ 6.040, de 7 de fevereiro de 2007, assentamentos rurais e agricultores familiares, definidos na Lei Federal $n^{\circ} 11.326$, de 24 de julho de 2006, visando ao fortalecimento da sua identidade e respeito à diversidade cultural, com a conservação, preservação, uso sustentável e recuperação dos recursos naturais;

$\mathrm{V}$ - fomentar o mercado de serviços ambientais;

VI - dar consequência, no âmbito estadual, ao Parágrafo 109 da Decisão da $21^{\text {a }}$

Conferência da Convenção-Quadro das Nações Unidas sobre Mudança do Clima, a COP 21, que se refere ao "reconhecimento do valor social, econômico e ambiental das atividades voluntárias de mitigação”. (PERNAMBUCO, 2016).

Observa-se que a postura adotada pela referida norma foi o incentivo na utilização de mecanismos baseados no princípio de reforço positivo, qual seja, o protetor recebedor, indo consequentemente ao encontro dos mais recentes acordos internacionais firmados nas Conferência das Partes (COPs). Ademais, outro ponto que merece destaque é a fundamental participação dos diversos atores sociais nesse processo de implementação, consubstanciado no fortalecimento de projetos que possuem como foco os povos e comunidades tradicionais além dos assentamentos rurais e agricultores familiares (Art. $2^{\circ}$, IV).

Nesse sentido, sob o aspecto finalístico, a PEPSA adota uma visão pautada no desenvolvimento sustentável, conforme aduz Veiga (2010), pois preza por uma união entre o econômico (os valores monetários revertidos com o PSA), o social (a participação ativa das comunidades diretamente beneficiadas) e o ambiental (o manejo sustentável de espaços naturais com a finalidade de conserva-los para as presentes e futuras gerações). Argumento que corrobora tal afirmação é o reconhecimento e incentivo ao mercado de PSAs tanto em razão da sua atuação econômica quanto pela sua vertente social (Art. $\left.2^{\circ}, \mathrm{I}\right)$. 
Outrossim, no que cabe ao patrimônio natural do Estado, a legislação reconheceu as especificidades inerentes as características dos diferentes biomas e a consequente necessidade de adaptação das metodologias de PSAs ao contexto local. Dessa maneira, alternativas como a REDD recebem o respaldo da PEPSA para fazer as modificações imperativas, sem desvirtuar os respectivos instrumentos, para melhor serem aplicadas em Pernambuco (Art. $2^{\circ}$, III).

Da mesma maneira, a política define como espaços-alvos (Art. $2^{\circ}$, II) aqueles que o próprio ordenamento jurídico considera como sensíveis sob a ótica ambiental: áreas de reserva legal (Lei Federal no 12.651/12 - Código Florestal), de preservação permanente (Lei Federal n ${ }^{\circ}$ 12.651/12 - Código Florestal), das unidades de conservação (Lei Federal no 9985/00 - SNUC), das áreas suscetíveis à desertificação (Lei Federal nº 13.153/15 Política Nacional de Combate à Desertificação e Mitigação dos Efeitos da Seca), das áreas estuarinas (Lei Federal n ${ }^{\circ}$ 12.651/12 - Código Florestal), das zonas de recarga de aquífero e/ou de abastecimento de mananciais (Lei Federal nº 12.651/12 - Código Florestal).

Com isso a PEPSA, pelo menos no âmbito da legislação, pacifica as discussões sobre a denominada dupla proteção institucional conferida a essas áreas. O contrato de REDD, assim como outros instrumentos previstos na política, é uma forma alternativa para o cumprimento das metas de redução de carbono e da proteção ambiental. Assim, além da clássica utilização do "comando e controle", que tem como função a indicação dos comportamentos legais e ilegais, instrumentos econômicos pela via do mercado ou por outras vias têm sido utilizados. Trata-se de forma inovadora no Direito Ambiental, pois permite a configuração de uma espécie de mercado que promove a participação privada diretamente na contribuição para a eficácia jurídica da realização do interesse público geral.

Os PSAs integram uma interpretação econômica da natureza, na medida em que utilizam conceitos de mercado, a ideia de capital natural e de produtores de serviços ambientais. Utilizam ainda uma lógica de custo de oportunidades, avaliando monetariamente as situações de se manter a floresta em pé. São instrumentos estratégicos que podem contribuir com a melhoria da eficácia jurídica da proteção ambiental.

Essa abordagem, contudo, ao mesmo tempo em que inova é criticada por incentivar a mercantilização da natureza e por enfatizar a possibilidade de uma falta de ética ambiental no tratamento econômico dos recursos naturais. Essa interpretação também pode ser aplicada na medida em que a cultura e o modo de vida dos povos que utilizam desses recursos naturais também se tornam passíveis de negociação, caso não sejam respeitados de modo expresso pelo contrato firmado entre as partes. 
Porém, a partir de um olhar técnico, tem-se construído, no Direito, a noção de que não se trata de um mercado de biodiversidade, mas sim de um mercado da obrigação jurídica de compensação, visto que esta foi a demanda criada pelo Estado que obriga a compensação das emissões de carbono. Torna-se, assim, um mercado de obrigações, ou um mercado de compensação, no lugar da mercantilização da natureza conforme as principais críticas afirmam.

Outro ponto controverso é o conceito de adicionalidade. Para que esta ocorra, deve haver diferença no que ocorreria na linha de base ou ausência do projeto (também chamado "negócios como sempre”). Se não houver esta diferença, não ocorreu tal fenômeno. A linha de base é o que ocorre na ausência de um projeto de REDD e a adicionalidade é a diferença, comparada à linha de base, correspondente ao que se deixa de emitir à atmosfera com o projeto (FERENCZY, 2009). Como observou Angelsen (2008), para a REDD ser efetivo e, consequentemente, seus objetivos serem alcançados, as reduções de emissões devem ser adicionais. Portanto, para o autor, deve ser feito uma "presunção realista do que ocorreria sem o projeto de REDD." (ANGELSEN, 2008).

Tomando como base esse argumento de Angelsen (2008), Ferenczy (2009) entendeu que as áreas de preservação permanente e as reservas legais não podem ser consideradas espaços aptos ao desenvolvimento de projetos de REDD, por consistirem em espaços que por força de lei, não podem ser desmatados, não ocorrendo, portanto, a adicionalidade caso projetos nesses espaços fossem desenvolvidos.

Neste ponto, Karousakis (2009) observou que, para efetivamente ocorrer redução de emissões por desmatamento e degradação, os incentivos financeiros devem ser direcionados às áreas que estejam em risco de serem convertidas a usos alternativos do solo. Salienta-se, no entanto, que esta identificação de áreas que estejam em risco não implica necessariamente a exclusão de áreas protegidas, já que projetos de REDD podem ser desenvolvidos em áreas protegidas que estejam sendo mal manejadas, sofrendo com falta de recursos e, portanto, não se desincumbindo com êxito na proteção dos processos ecológicos essenciais. O fator adicionalidade estaria, portanto, também presente nesta situação (KAROUSAKIS, 2009).

Neste ponto merecem destaque as constatações da International Union for Conservation of Nature (IUCN):

Atualmente, muitas áreas protegidas são mal manejadas ou existem apenas no papel, estas áreas se incluem nas estatísticas nacionais de conservação da natureza, mas falham em prover os benefícios geralmente associados às áreas protegidas. Melhorar a efetividade de áreas protegidas se torna assim um objetivo-chave. (IUCN, 2010, p.12) 
Ora, admitir que toda área protegida não sofre nenhum tipo de pressão, seja essa de cunho político, social ou econômico, é na verdade acreditar na plena eficiência das leis e das políticas governamentais de conservação. Infelizmente, tal situação não ocorre. Os problemas vão desde a falta de fiscalização até a falta de conscientização da própria sociedade. Entendese que o posicionamento de Karousakis (2009) é o mais acertado, tendo em vista que com esse seria possível abranger um maior número de espaços territoriais e além disso envolver diretamente a população.

Não existe dúvida que a obrigação de conservar deveria ser cumprida sem precisar de nenhum tipo de incentivo econômico. Todavia, os resultados apresentados não parecem satisfatórios no que cabe à conservação da Caatinga e Mata Atlântica (SOS MATA ATLÂNTICA; INPE 2015; PERNAMBUCO, 2011), cabendo, portanto, uma discussão mais ampla sobre outras alternativas ligadas aos PSAs.

Atento a esta situação, o legislador assumiu um posicionamento expresso no que cabe às áreas que podem receber os projetos da REDD. De acordo com o Art.13, §4 $4^{\circ}$, somente são elegíveis as áreas preservadas além do mínimo estabelecido pela legislação florestal nacional e estadual, em particular além das áreas de preservação permanente e da reserva legal compulsória, e com uso voluntariamente restringido por meio de servidão florestal, instituição de reserva particular do patrimônio natural ou averbação de reserva legal além do mínimo legal (PERNAMBUCO, 2016). Portanto, o sistema jurídico pernambucano adotou o posicionamento de Ferenczy (2009).

Para consecução dos objetivos propostos foi necessária a criação de um arcabouço jurídico e institucional (Figura 6) no qual fosse clara a definição de atribuições para todos os órgãos envolvidos. Como órgão responsável pela arquitetura estadual na seara ambiental e pela sua própria atribuição no SISNAMA e no SISEMA, a função de planejamento, coordenação e controle da implementação é da Secretaria Estadual de Meio Ambiente e Sustentabilidade (SEMAS) (Art. $5^{\circ}$ ).

A SEMAS, segundo definição da política, também possui como competência: (I) acompanhar as ações para atendimento das diretrizes da PEPSA; (II) articular ações nas diferentes instituições governamentais; (III) apoiar a realização de estudos, pesquisas e ações; (IV) disponibilizar e manter atualizadas as informações acerca das áreas contempladas com os projetos de PSA, assim como os serviços prestados por essas áreas e o valor percebido pelo beneficiário a título de remuneração; (V) garantir a transparência e o controle social dos programas, subprogramas, planos de ação e projetos de PSA; (VI) implementar o cadastro das 
áreas prioritárias para projetos de PSA; e (VII) aprovar atos normativos voltados ao disciplinamento das ações.

Figura 6 - Arranjo institucional da PEPSA

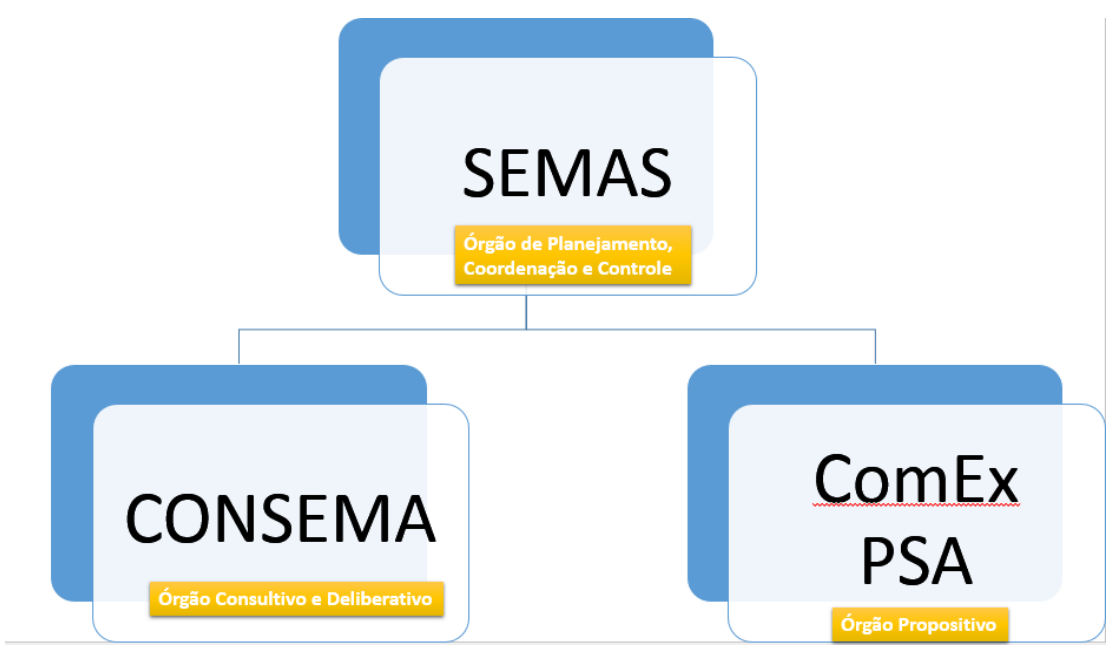

Fonte: Elaborada pelo autor.

É evidente, pelas disposições normativas, que ao conferir as atribuições acima elencadas o legislador optou por criar um verdadeiro órgão diretivo na implementação da PEPSA. Contudo, é importante não olvidar que em razão dos princípios do Direito Ambiental, como da informação e da participação popular, a SEMAS não possui a "última palavra", podendo suas decisões serem revistas de ofício (autotutela) ou até mesmo por provocação ao poder judiciário.

Devido ao seu caráter pioneiro na ordem legal, assim como em razão da lacuna existente no organograma ambiental do Estado, fez se fundamental a criação de um organismo com caráter propositivo que atuasse em harmonia com a Secretaria de Meio Ambiente e que tivesse como principal característica a composição heterogênea e interinstitucional dos seus participantes, o denominado Comitê Executivo do programa estadual de PSA (ComEx PSA).

A formação desse Comitê é regulamentada pelo Decreto nº 43.128/2016 e compreende um representante e um suplente dos seguintes órgãos: (I) Secretaria de Meio Ambiente e Sustentabilidade; (II) Agência Estadual de Meio Ambiente-CPRH; (III) Secretaria de Desenvolvimento Econômico; (IV) Agência de Desenvolvimento de Pernambuco - ADDIPER; (V) Agência Estadual de Águas e Clima - APAC; (VI) Secretaria de Agricultura e Reforma Agrária; (VII) Instituto Agronômico de Pernambuco - IPA; e (VIII) Secretaria de Ciência, Tecnologia e Inovação. 
A preocupação na criação desse órgão foi garantir a participação das diferentes esferas do Poder Público executivo, levando em consideração órgãos basilares da seara econômica e da proteção ambiental, além de também incluir setores da agrícola e da ciência e inovação. A coordenação do Comitê fica sob responsabilidade da SEMAS. Cabe salientar que, por meio da coordenação, é possível convidar pessoas e representantes de outras instituições para participarem de atividades consideradas relevantes para o cumprimento de suas atribuições.

Nesse sentido, o ComEx PSA tem como caráter marcante seu viés propositivo tendo em vista que sua principal função é definir e propor ao Conselho Estadual de Meio Ambiente (CONSEMA) critérios e parâmetros para implementação do PSA, como por exemplo critérios de cálculo e forma de remuneração a ser paga aos provedores, considerando-se a importância do serviço ambiental prestado, a extensão da área, a condição socioeconômica do beneficiário, entre outros parâmetros definidos em regulamento (Art.6 $6^{\circ}$, II) e os parâmetros técnicos e científicos a serem utilizados na avaliação e monitoramento dos serviços ambientais passíveis de remuneração (Art. $6^{\circ}$, IV).

O terceiro órgão participante do arranjo institucional para implementação da PEPSA é o CONSEMA (Art. $7^{\circ}$ ). Este possui carácter consultivo e deliberativo, assumindo um lugar de protagonismo pois é ao Conselho que cabe a análise das propostas criadas pelo ComEx PSA. De acordo com a PEPSA, o CONSEMA possui como atribuições: (I) analisar e deliberar sobre os critérios e parâmetros definidos pelo Comitê Executivo para os subprogramas e projetos de PSA; (II) aprovar a prestação de contas dos dispêndios realizados pelo Fundo Estadual de Pagamento por Serviços Ambientais; e (III) fixar normas complementares sempre que necessário. Cabe salientar que as câmaras técnicas do CONSEMA poderão ser convocadas para subsidiar tecnicamente as deliberações do referido Conselho, bem como propor alternativas para melhoria das ações de implementação da Política e dos subprogramas de PSA.

Essas competências são responsáveis pela efetivação da PEPSA e para tanto também foram criados os instrumentos para consecução dos objetivos previstos no Art. $2^{\text {o }}$ : (I) Programa Estadual de Pagamento por Serviços Ambientais; (II) cadastro estadual de Áreas Prioritárias para PSA; (III) inventário do capital natural do Estado; (IV) sistema estadual de informações sobre PSA; e (V) Fundo Estadual de Pagamento por Serviços Ambientais.

O Programa Estadual de PSA tem como objetivo implementar a política de PSA para a preservação, a conservação e a recuperação dos ecossistemas e a manutenção e incremento da oferta dos serviços ambientais e ecossistêmicos (Art. $9^{\circ}$ ). Essa é uma ferramenta macro que abriga cinco subprogramas: (I) Subprograma PSA Restauração; (II) Subprograma PSA 
Biodiversidade; (III) Subprograma PSA Água; (IV) Subprograma PSA Carbono; e (V) Subprograma PSA Beleza Cênica.

Os subprogramas são verdadeiras linhas de ações temáticas que vão balizar o contrato de PSA assim como seus requisitos. Ou seja, os critérios para o PSA Biodiversidade e o PSA Água, por exemplo, são diferentes e possuem regulamentações distintas, contudo nada impede que em uma mesma localidade seja incluída em mais de um subprograma, desde que os requisitos de ambos sejam cumpridos. Em razão do objetivo da presente pesquisa apenas será analisado o PSA Carbono.

O Subprograma PSA Carbono vem disciplinado no Art. 13 e apoia projetos voltados a reduções ou sequestro comprovados de emissões de GEE, efetuados por aqueles que desenvolvam ações de mitigação de emissões de GEE oriundas de: (I) desmatamento e degradação, bem como à manutenção e aumento dos estoques de carbono florestal (REDD+); (II) agricultura e pecuária; (III) energia; (IV) transportes; (V) indústria; e (VI) gestão de resíduos. O arranjo institucional do PEPSA promoverá a compensação de emissões provenientes de atividades produtivas, através de arranjos locais, sem prejuízos para eventuais acordos dentro das normatizações dos mercados convencionais ou voluntários (Art. 13, $\S 1^{\circ}$ ). Nesse sentido, será dada prioridade para projetos que envolvam comunidades ou populações tradicionais assim como aquelas que envolvam assentamentos rurais.

Outro critério definidor na escolha das áreas receptoras é a priorização daquelas que, por critérios técnicos e legais, tais como tamanho, status de conservação e regime de uso, sejam mais restritivas em termos de conservação (Art. 13, §2 $2^{\circ}$. Logo, se houver recurso para implementar o PSA em apenas um espaço e exista a concorrência de mais de um, será beneficiado aquele que reúna essas características de forma isolada ou cumulativamente.

Outrossim, cabe uma ressalva no que tange aos espaços elegíveis. Somente são aptos para o Subprograma PSA Carbono as áreas preservadas além do mínimo estabelecido pela legislação florestal nacional e estadual, em particular além das áreas de preservação permanente e da reserva legal compulsória, e com uso voluntariamente restringido por meio de servidão florestal, instituição de reserva particular do patrimônio natural ou averbação de reserva legal além do mínimo legal (Art.13, §4º).

Outra vedação em relação ao PSA Carbono é a utilização de áreas com florestas plantadas com espécies exóticas. Tal exclusão serve para resguardar as áreas nativas ou em recuperação e evitar que esses espaços sejam desmatados para em seu lugar ocorrer o plantio de espécies como o eucalipto e o pinus, ambas de rápido crescimento. Com isso evita-se um estimulo ao plantio desenfreado dessas espécies em busca de um suposto sequestro de 
carbono desses espaços. Ora, como o próprio objetivo da PEPSA prega, o fim desta reside na manutenção dos espaços naturais conjuntamente com o manejo e recuperação destes.

Portanto, A PEPSA demonstra que existe um ambiente planejado e estruturado não apenas para implementação da REDD, mas sim para qualquer iniciativa que tome como base o conceito de PSA, pois além de trazer requisitos claros para implementação traz consigo critérios de elegibilidade para os projetos que desejam se incluir na proteção legal da política.

\subsection{CARACTERÍSTICAS DA REDD EM PERNAMBUCO}

A implementação da REDD exige a definição clara de três elementos, quais sejam: financiamento, áreas receptoras e beneficiários. Nessa seção serão discutidos essas características comparando a legislação pernambucana com as leis do estados do Acre e Mato Grosso.

\subsubsection{Financiamento}

A PEPSA prevê que o Estado poderá financiar os projetos REDD realizados com a participação de recursos públicos e estes serão vinculados aos subprogramas previstos nos incisos I a V, Art. $9^{\circ}$ (PERNAMBUCO, 2016). A adesão será voluntária e formalizada por contrato firmado entre o provedor do serviço ambiental e a SEMAS (Secretaria de Meio Ambiente e Sustentabilidade) e/ou outros beneficiários que usufruam diretamente do serviço prestado (PERNAMBUCO, 2016).

Por esse primeiro indicativo percebe-se que a postura praticada em Pernambuco é mais de participação regulatória do que de provimento da REDD. O provedor de serviços ambientais só poderá receber recursos financeiros do Estado se efetuar o cadastro no denominado Programa Estadual de Pagamento por Serviços Ambientais. Como requisitos, o provedor deverá: (i) comprovar de uso ou ocupação regular do imóvel; (ii) formalizar instrumento contratual específico; e (iii) assinar termo de adesão ao programa no qual o proponente do projeto se compromete a regularizar ambientalmente o imóvel, no que diz respeito a licenciamento ambiental, adequação da reserva legal e áreas de preservação permanente, bem como a inscrição no Cadastro Ambiental Rural, quando for o caso (PERNAMBUCO, 2016).

Consideração merece ser feita em relação ao requisito "iii” para adesão ao Programa de PSA. Imóveis que não estão totalmente adequados à legislação ambiental poderão se candidatar desde que se comprometem a regularizar sua situação junto aos órgãos ambientais. Tal ação pode ser vista como um incentivo para que potenciais provedores de carbono façam 
a adesão ao programa e com os recursos provenientes possam se adequar às leis ambientais. Todavia, cabe ressaltar que na PEPSA não é informado a prazo para isto ser feito e nem a maneira que será fiscalizado.

Como afirmado anteriormente, Pernambuco criou, com o advento da PEPSA em seu Art. 21, o Fundo Estadual de Pagamentos por Serviços Ambientais, seu fundo público próprio para financiar iniciativas de PSA. A gestão fica a cargo da Agência de Fomento do Estado de Pernambuco (AGEFEPE), competindo ao Conselho Estadual de Meio Ambiente (CONSEMA) a supervisão da aplicação dos seus recursos.

Os recursos desse fundo são provenientes de: (i) dotações orçamentárias destinadas ao programa; (ii) recursos decorrentes de convênios ou outros instrumentos congêneres celebrados com órgãos e entidades da administração pública federal, estadual ou municipal, ou com entidades da sociedade civil; (iii) recursos provenientes da compensação ambiental; (iv) doações de pessoas físicas e/ou jurídicas de direito público e/ou privado destinadas ao programa; e (v) receitas provenientes da precificação positiva das ações de mitigação, conforme definidas em instrumento legal com entes públicos e privados nacionais, internacionais ou multilaterais (PERNAMBUCO, 2016).

De maneira mais clara, em relação ao ponto “ii”, o fundo vai obter recursos dos Órgãos da Administração Pública, além de entidades da sociedade civil, como por exemplo repasses, protocolos de intenções, Convênios com a COMPESA (Companhia Pernambucana de Águas e Saneamento, CELPE (antiga Companhia Elétrica de Pernambuco, atual grupo espanhol Neoenergia), empresas, cláusulas de contratos celebrados pelo Governo. Ademais, também podem ser obtidos recursos por meio de captação junto a outros fundos, a exemplo do Fundo Estadual de Meio Ambiente (FEMA) e do Fundo Estadual de Combate à Desertificação e Mitigação dos Efeitos da Seca, entre outros.

Nota-se pelas fontes de captação do fundo que ele é preponderantemente dependente de vontade política para seu abastecimento. Do “i” ao “iii” são essencialmente decisões políticas assumidas pela administração pública junto a Assembleia Legislativa do Estado (i), perante convênios com outros entes da administração pública (ii) e por fim os recursos das compensações ambientais proveniente do Sistema Estadual de Unidades de Conservação (SEUC) que apesar de ser uma previsão legal é incisivamente fatiado em outros setores ambientais (iii).

Vale ressaltar que a previsão da compensação ambiental é incongruente com o sistema previsto na PEPSA, pois apenas uma modalidade de Unidade de Conservação em Pernambuco (PERNAMBUCO, 2016) é passível de receber projetos REDD que é a RPPN, 
espécie de UCs enquadrada dentro do grupo "uso sustentável” que possui uma especificidade: é instituída por particular. Tal característica levanta o questionamento da real intenção da REDD no Estado. Se é fomentar um real mercado de carbono, financiando, na medida do possível e com critérios técnicos, as mais variadas áreas, propiciando uma participação ampla de diversos atores ou incentivar nichos muito bem delimitados, como é o caso das RPPNs.

Diferentes modalidades de financiamento podem estar atreladas ao uso de diferentes instrumentos econômicos para a implantação da REDD. Assim, modalidades de financiamento não são apenas as formas escolhidas para levantar recursos para o REDD, mas também impactam e são impactadas pela própria estrutura do mecanismo, estando intimamente relacionadas aos entendimentos teórico-conceituais a partir dos quais pode ser concebido e aplicado (ANGELSEN et al., 2018; DAWSON et al., 2018).

A respeito do financiamento da REDD, o posicionamento de Pernambuco é bem claro. O Estado atuará como participante no fomento, por meio do seu fundo público e como intermediário (fiscalizando) em projetos privados, seja como fomentador dos elementos (SALLES et al., 2017) ou com Ações REDD propriamente ditas.

O papel de intermediário é relativamente comum nos projetos REDD. Os intermediários têm papel central para conectar usuários da terra a financiadores, e têm grande influência na formatação dos incentivos e na redução de custos de transação (SATHLER et al., 2015). Esta observação também está relacionada ao papel que estes intermediários podem ter para a redução de custos de transação, de modo a viabilizar transações de mercado no nível de projetos.

Cabe dizer que a única menção feita aos mercados voluntários, diga-se privados, é no Art. $13, \S 1^{\circ}$ no qual Pernambuco se compromete a incentivar a compensação de emissões provenientes de atividades produtivas, através de arranjos locais, sem prejuízos para eventuais acordos dentro das normatizações dos mercados convencionais ou voluntários. Contudo tal escopo está inserido não apenas no âmbito da REDD, mas sim em qualquer atividade que atue na emissão de carbono, logo também estão compreendidos projetos de Mecanismo de Desenvolvimento Limpo (MDL) que podem incluir: agricultura e pecuária; energia; transportes; indústria; e gestão de resíduos. Logo, em termos de financiamento, não é feita nenhuma menção ao mercado privado ligado ao REDD a ser incentivado pela PEPSA.

A explicação para a verdadeira ausência de qualquer tipo de disposição acerca do setor privado na REDD pernambucana pode ser interpretada como a aceitação que o Estado ainda não possui infraestrutura capaz de regular e garantir o mínimo de segurança econômica para os possíveis investimentos privados. Um exemplo disso é que um dos pontos-chave para 
qualquer estratégia REDD são as ações e práticas de medição, registro e verificação (MRV) das emissões (ANGELSEN et al., 2018) e essas não são discutidas em nenhum momento.

$\mathrm{Na}$ PEPSA não fica claro “quem” vai desempenhar tal atribuição. Se vai ser o próprio provedor do recurso? E se caso for, qual o papel de Pernambuco? Acre e Mato Grosso criaram organização próprias de registro e auditoria das emissões certificáveis dos projetos. O modo como foram descritas as atribuições passa a impressão que Pernambuco tem o desejo de implementar a REDD, mas não admite que ainda não possui uma estrutura necessária (monitoramento de áreas, certificação, recursos técnicos e humanos) para o investimento privado e nem assume para si a responsabilidade de desenvolver esse arcabouço.

Nesse sentido, o Estado poderia, em um primeiro momento, melhorar as competências técnicas (parcerias com as instituições de ensino e outros órgãos ambientais congêneres em outros estados) para atrair o setor privado. Somam-se a isso a indefinição aparente e incongruência em qual parte da REDD haverá uma atuação mais incisiva: (I) no início (que seria o mais adequado nesse primeiro momento), organizando os provedores interessados em obter a certificação do carbono e dar subsídios financeiros e legais para seu aprimoramento; (II) no meio, apenas fiscalizando a comercialização entre os provedores e o setor privado; ou (III) no fim, apenas comprando os certificados dos provedores e revendendo no mercado de carbono (MMA, 2016).

O modelo adotado pelos Estados do Acre e do Mato Grosso foram mais próximos do pensado na UNFCCC (2017), tendo em vista a sua autonomia e ao mesmo tempo uma integração em relação a outras políticas (ACRE, 2010; MATO GROSSO, 2013; UMUNAY et al., 2018; NEPSTAD et al., 2018), possuindo inclusive órgãos e fontes de financiamentos exclusivos para a modalidade carbono. Ao passo que em Pernambuco a REDD foi prevista como um subprograma dependente de uma política maior de PSA (PERNAMBUCO, 2016). Fato que corrobora o ponto de vista é a não constituição de um fundo próprio para a REDD e sim um Fundo Estadual de Pagamento por Serviços Ambientais, centralizando toda forma de repasse de recurso bem como pulverizando o montante em diversas iniciativas de PSAs.

Na legislação acreana (Lei Estadual no 2.308/10), diferentemente de Pernambuco, o Estado assume uma postura muito mais promotora da REDD (DAWSON et al., 2018). Nela não foi criado um fundo público para fomento das atividades REDD, contudo foi pensada uma sociedade de economia mista denominada Agência de Desenvolvimento de Serviços Ambientais do Estado do Acre. Essa sociedade de economia mista funciona basicamente como um representante do Acre no mercado de carbono, possuindo como objetivos: (I) desenvolver estratégias voltadas à captação de recursos financeiros e investimentos; (II) 
captar recursos financeiros oriundos de fontes públicas, privadas ou multilaterais, sob a forma de doações e/ou investimentos nos programas, subprogramas e planos de ação; (VII) gerir e alienar, na medida de suas competências, os ativos e créditos resultantes dos serviços e produtos ecossistêmicos oriundos dos programas, subprogramas, planos e projetos (ACRE, 2010).

Ademais uma outra característica do modelo acreano merece destaque. O Estado pode ser o provedor de serviços ambientais, atuando diretamente na venda de créditos de carbono desde que seja proveniente de serviços na sua titularidade ou que estejam sob sua administração (ACRE, 2010). Tal hipótese é prevista no Art. 39 da Lei Estadual. Logo, em uma UC estadual, independentemente da modalidade, que apresente vegetação nativa, caso o Estado consiga comprovar que houve uma redução do desmatamento e esse fato foi monitorado e certificado, esses créditos podem ser alienados no mercado de carbono, tornando-se receita para o Acre reaplicar no sistema ou em outra área de interesse correlata.

$\mathrm{Na}$ legislação mato-grossense (Lei Estadual $n^{\circ}$ 9.878/13) foi criado um verdadeiro Sistema Estadual da REDD. No Mato Grosso, o agente estatal funciona como um verdadeiro regulador da atividade (DAWSON et al., 2018). Para conseguir realizar qualquer tipo de ação REDD no Estado, seja por meio de fundos públicos ou privados, o provedor deve ter seus serviços ambiental aprovados e monitorados pela Secretaria de Meio Ambiente (SEMA) que após análise e verificação das reduções poderá conceder créditos de redução de emissões.

Além disso, foi criado um fundo público específico, denominado Fundo Estadual de REDD, que é tutelado pelo Conselho gestor, órgão responsável pela direção do Sistema Estadual da REDD, possuindo poderes deliberativos e composto por diversos membros da sociedade. Esse Conselho tem o poder de decidir para qual projeto vai cada recurso.

Os recursos provenientes desse fundo são de dotações orçamentárias, doações e parcerias de agentes públicos e privados, nacionais e internacionais que visem à redução de emissões por desmatamento/degradação florestal e ao aumento de remoções, bem como recursos obtidos junto aos mercados de carbono, incluindo a venda pelo Estado de títulos oriundos de reduções de emissões ou aumentos de remoções devidamente registradas, entre outras fontes (MATO GROSSO, 2013).

Assim como no Acre, o Art. 28 autoriza o Mato Grosso a atuar diretamente no mercado de carbono, podendo alienar em Bolsas de Valores, Mercadorias e de Futuros e entidades administradoras de mercados de balcão organizado, autorizadas a funcionar pela Comissão de Valores Mobiliários - CVM, no Mercado Brasileiro de Reduções de Emissões 
(MBRE) ou em outros mercados nacionais ou internacionais que respeitem a legislação nacional e internacional em vigor (MATO GROSSO, 2013).

Nesse sentido, fica claro que Pernambuco adotou uma postura mais conservadora e tímida na atuação do mercado de carbono, resguardando-se apenas a regular e fomentar (ambas de maneira muito incipiente) as iniciativas da REDD, em sua maioria voltadas para obtenção de recursos nos fundos públicos. Do outro lado, Acre e Mato Grosso demonstraram uma postura mais atuante, pois além de fiscalização/regulação existe também uma previsão de atuação ativa no mercado (fundo próprio da REDD), podendo inclusive atuar diretamente nele com a compra e venda de créditos de carbono no setor privado.

Com essas características, esses dois Estados mostram-se mais abertos, tanto para a obtenção de recursos em fundos públicos, quanto para atuação e fomento do setor privado. Todavia, o quadro nacional ainda é mais constituído por recursos provenientes de fundos públicos. No estudo publicado por Salles et al. (2017), referente ao recorte temporal até o ano de 2015, o Brasil havia apresentado 89 projetos de REDD. A maior parte estava sendo financiada pela modalidade de fundos públicos, totalizando 74 projetos (83\%). Os financiados pela modalidade de mercado somavam 15 projetos $(17 \%)$.

A explicação para a prevalência dos fundos públicos deve-se ao estádio embrionário do Brasil, enquanto estratégia nacional, nessa temática. Durante as fases iniciais, esse processo enfrenta altos custos de comunicação, monitoramento e transação, e favorece países que têm proponentes de REDD sediados nos países doadores (NEUDERT et al., 2018; DAWSON et al., 2018), como aqueles que receberam ajuda do país doador no passado ou projetos propostos agrupados com outros países, a exemplo do Acre (SALLES et al., 2018).

É nessa característica que reside a importância dos fundos multilaterais. Eles têm uma vantagem comparativa sobre os mecanismos bilaterais de financiamento, pois possuem capacidade especializada - tanto técnica (por exemplo, seguindo as diretrizes da UNFCCC) quanto de governança (por exemplo, fiduciária e salvaguardas) - e podem cultivar grandes redes de países engajados em atividades semelhantes (VIANA, 2009). Esses programas influenciam significativamente a forma como os fundos são estruturados, usados, fornecidos e relatados pelos países e doadores de REDD.

Os principais mecanismos de financiamento multilateral focados para a REDD são o Fundo de Apoio à Facilidade de Parceria do Carbono Florestal (FCPF-RF), os Programas Nacionais UN-REDD (NP) e o Programa de Investimento Florestal (FIP) dos Fundos de Investimento Climático (CIF), além do Green Climate Fund (GFC) (OLESEN et al 2018). No entanto, muitos doadores que contribuem para esses três fundos também fornecem 
financiamento para os países da REDD diretamente, por meio de acordos bilaterais, a exemplo da Noruega e da Alemanha.

Nesse sentido, cabe a Pernambuco, assim como outros Estados, desenvolver mecanismos flexíveis que possam canalizar o financiamento para diferentes setores, usando uma variedade de instrumentos financeiros (por exemplo, doações, empréstimos), tanto de fontes públicas quanto privadas. Se a definição da REDD estiver melhor alinhada com o que os países precisam, pode haver um apoio interno mais forte para REDD e uma variedade maior de oportunidades de negócios que complementem seus objetivos (DAWSON et al., 2018).

Apesar da aparente abundância de fundos públicos, espera-se que o setor privado assuma um papel maior no financiamento de iniciativas da REDD (NEUDERT et al., 2018), seja desenvolvendo projetos de carbono florestal seja adquirindo créditos de carbono da vegetação pernambucana. Fatores como os riscos relacionados a posse da terra, propriedade de carbono e regras de comercialização de créditos podem levar à perda de direitos de carbono gerados por projetos privados alinhados aos programas estaduais da REDD, tornando o investimento menos atraente.

Por essa ótica, a boa governança é essencial para que o financiamento do setor privado seja significativo para REDD (PETERSEN et al., 2018). A experiência de outros setores revela que transformar ativos de público em privado (por exemplo, privatizando serviços ecossistêmicos florestais) precisa ser cuidadosamente regulado e monitorado para evitar a captura regulatória (ANGELSEN et al., 2018). Por exemplo, no início da implementação de REDD em outros países, as empresas beneficiaram-se da falta de compreensão do funcionamento dos mercados de carbono e os reflorestamentos tiveram efeitos negativos nas comunidades locais e no meio ambiente devido à má alocação de fundos públicos e à desapropriação das comunidades locais (PETERSEN et al., 2018). Enquanto isso, as empresas socialmente responsáveis sofreram porque não tinham apoio político, regulatório e de aplicação da lei para implementar salvaguardas adequadas.

O setor privado também precisa do apoio do Governo de Pernambuco - através de um melhor planejamento do uso da terra, regulamentação e financiamento público - para manter o interesse em colocar os compromissos em ação. O Poder Público precisa adotar e fazer cumprir as leis existentes (REIS NETO et al., 2018), formular políticas e apoiar os agricultores mais pobres por meio de sua transição para a REDD nem que seja como uma renda complementar. 
Salles et al. (2017) verificaram que, em média, existem diferenças significativas entre ambas modalidades de financiamento (pública ou privada). Por exemplo, quanto feito por fundos públicos os projetos duram em média três anos, enquanto projetos de mercado têm 30 anos de execução. Ademais, características como Auditorias (quanto feito pelo setor privado adota critérios mais objetivos e são periódicas) e abrangência geográfica (por fundo público as áreas são bem maiores) sofrem influência direta em relação ao tipo de financiamento escolhido (SALLES et al., 2017).

Seis Estados da Amazônia brasileira receberam um total de US \$ 220 milhões em financiamento através do Fundo Amazônia e os requisitos de desempenho ficaram sob a responsabilidade do governo nacional (BNDES, 2014). O programa REDD Early Movers da Alemanha fez contribuições importantes para a estratégia da REDD no Acre e estabeleceu um contrato com Mato Grosso - as únicas jurisdições estudadas que receberam (ou estavam programadas para receber) financiamento direto baseado em resultados. Essas jurisdições também são as mais bem posicionadas para atender ao proposto Padrão de Floresta Tropical da Califórnia (NEPSTAD et al., 2018). Há necessidade de fontes de financiamento adequadas e diversificadas para apoiar Estados que estão em estágios iniciais e intermediários de progresso, como é o caso pernambucano.

Portanto, percebe-se que a legislação de Pernambuco segue uma tendência nacional de predileção por fundos públicos. Tal características pode ser explicada tanto pela grande dificuldade de auto-organização do Estado para obtenção dos diversos procedimentos necessários para aceitação no mercado voluntário quanto pelo desinteresse do setor privado pelo quadro institucional atual presente no tocante à REDD. Em grande medida, o desafio da iniciativa pernambucana é, em um primeiro momento, criar e fomentar iniciativas financiadas pelos fundos público, para em um segundo momento, com uma estrutura adequada e propícia, abrir e difundir o mercado voluntário de carbono no ambiente empresarial.

\subsection{2 Áreas receptoras: Caatinga pernambucana}

Em Pernambuco, logo fica evidente um equívoco cometido na previsão da REDD. O legislador estadual reduziu os campos de atuação do instrumento. A áreas são definidas pelo Art. $13, \S 4^{\circ}$ :

Art. $13(\ldots)$

$\S 4^{\circ}$ Somente são elegíveis para o Subprograma PSA Carbono as áreas preservadas além do mínimo estabelecido pela legislação florestal nacional e estadual, em particular além das áreas de preservação permanente e da reserva legal compulsória, e com uso voluntariamente restringido por meio de servidão florestal, instituição de 
reserva particular do patrimônio natural ou averbação de reserva legal além do mínimo legal. (PERNAMBUCO, 2016)

A fórmula de criação da REDD poderia ser mais abrangente em suas soluções quando reconhecem os espaços potenciais para implementação. $\mathrm{O}$ primeiro ponto reside no fato que o número atual de RPPNs no bioma é baixo, apenas nove ${ }^{5}$ (Figura 7). Segundo, não existe no Estado um sistema de informações geográficas que contabilize de maneira informatizada as servidões ambientais constituídas e as reservas legais averbadas em cartório, dificultando sobremaneira a contabilização e controle desses espaços. O SISCAR apenas contabiliza as áreas referentes ao mínimo legal de APPs e RLs.

Figura 7 - Caatinga pernambucana e áreas potenciais para a REDD

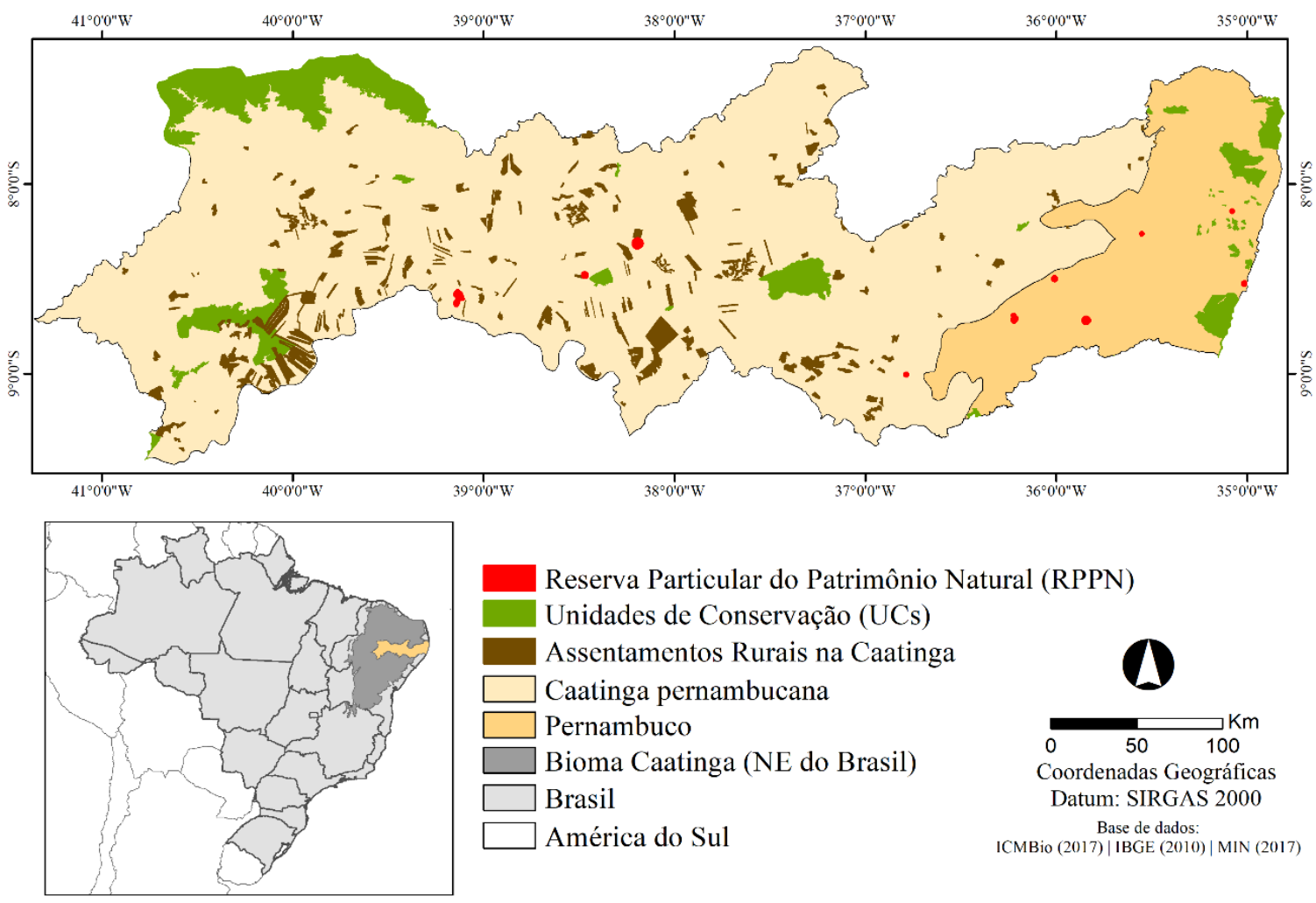

Fonte: Adaptado de ICMBIO (2017), IBGE(2010) e INCRA(2016).

Ademais, ainda sobre as RPPNs, não existe uma justificativa clara para sua escolha. $\mathrm{O}$ argumento de incentivo a criação de novas RPPNs esbarra na falta de infraestrutura técnica do Estado em prover mais incentivos financeiros para essas áreas. Apenas a possibilidade da REDD não seria suficiente para aumentar marcadamente a quantidade dessas áreas. Além

5 (I) Reserva Siriema (290,93 ha - Belém do São Francisco), (II) Reserva Jurema (267,50 ha- Belém do São Francisco), (III) Reserva Umburana (131,02 ha - Belém do São Francisco), (IV) Reserva Cantidiano Valgueiro de Carvalho Barros (285,50 ha - Floresta), (V) Reserva Ecológica Maurício Dantas (1485 ha - Betânia), (VI) Bituri (110,21 ha - Brejo da Madre de Deus), (VII) Pedra do Cachorro (22,90 ha - São Caetano), (VIII) Reserva Cabanos (6 ha - Altinho), e (IX) Reserva Natural Brejos (52,39 ha - Saloá) (ICMBIO, 2017). 
disso, dificilmente conseguiria propiciar a participação popular, tendo em vista que, em regra, a instituição dessa modalidade é feita por proprietários de grandes áreas, que desejam isenção de impostos e facilidade na obtenção de crédito. Perde-se, sob essa ótica, a falta da inclusão de comunidades na gestão de programas REDD.

A própria opção também pelas APPs e RLs excedentes demonstra a falta de simetria entre os objetivos da REDD e o diploma legal pernambucano. Dadas as características do bioma, e conforme ilustra a Figura 7, uma área que poderia fazer parte da iniciativa REDD são os assentamentos rurais, que apenas na Caatinga passam de 50 (INCRA, 2016). Com a integração desses espaços, poderia ser conseguida a participação de comunidades rurais e ainda trazer algum tipo de recurso financeiro com a venda dos créditos de carbono.

Apesar da discussão no meio acadêmico a respeito da inclusão das UCs de proteção integral em estratégias REDD (REIS NETO et al., 2018), essa possibilidade foi desconsiderada em Pernambuco. Áreas como o Parque Nacional do Vale do Catimbáu poderia receber recursos provenientes da comercialização do carbono, bem como o Refúgio da Vida Silvestre do Tatu-Bola. Deixa-se de conseguir uma fonte alternativa para esses espaços. Na legislação matogrossense, os recursos obtidos vão diretamente para as áreas provedoras dos recursos por expressa previsão legal (MATO GROSSO, 2013)

No Mato Grosso, assim como no Acre, as áreas que podem ser passíveis de receber a REDD são: (I) unidades de conservação legalmente instituídas; (II) terras indígenas; (III) territórios quilombolas; (IV) outras áreas legitimamente ocupadas por populações tradicionais; (V) assentamentos rurais da reforma agrária; (VI) propriedades e posses rurais de domínio privado; (VII) outros imóveis rurais de domínio público. (ACRE, 2008; MATO GROSSO, 2013).

Além de tudo, por disposição expressa, nas áreas referidas para fins de sua participação no Sistema REDD, deve ser garantida a participação das populações legalmente residentes em todas as etapas e processos de tomada de decisão, incluindo os referentes à definição, negociação e repartição dos benefícios estabelecidos, observado o princípio do consentimento livre, prévio e informado, mediante procedimento próprio regulamentado (MATO GROSSO, 2013).

Em comparação com Pernambuco, até as RLs e as APPs devidamente regularizadas serão elegíveis para Programas e Projetos de REDD (Art. 33). No sistema pernambucano são susceptíveis de participação apenas aquelas que excedem o mínimo estabelecido (PERNAMBUCO, 2016). 
Essas políticas são veículos-chave para implementar a REDD como uma ferramenta multiobjetiva para conservação e desenvolvimento, e estão frequentemente alinhadas com estratégias e objetivos preexistentes (SATHLER et al., 2015). Fica claro por meio da comparação feita com o Mato Grosso e do Acre que o sistema pernambucano falha na restrição dos espaços potenciais, podendo até ser classificado como excludente em relação à participação de comunidades, em razão das características das áreas potenciais.

Nesse caso, em princípio, perde-se a oportunidade da REDD, no contexto estadual, de beneficiar a população local, colocando os direitos de propriedade/posse nas agendas econômicas e ambientais, esclarecendo/fortalecendo a posse florestal local para impedir a conversão de florestas por concorrentes externos, permitindo um sistema de recompensa benéfico para a proteção florestal e produzindo equitativamente distribuição de recursos através da venda de créditos de carbono florestal ou outros benefícios para as comunidades, bem como na inclusão de outras atividades econômicas.

Somente com a participação de áreas como os assentamentos rurais (Figura 7) Pernambuco teria a oportunidade de: (I) identificar os titulares de direitos para os recursos REDD; (II) diminuir os danos potenciais causados pela agricultura convencional por meio de assistência técnica especializada; (III) introduzir ou reforçar a silvicultura comunitária; e (IV) colaborar, consultar e negociar com as partes interessadas locais de REDD em assuntos de interesse mútuo, tais como projeto, implementação e monitoramento.

A disposição geográfica dos diversos assentamentos, bem como a sua reduzida extensão não seriam impedimentos para gestão da REDD. Assim, como afirmam Libert Amico e Trech (2016), passa a ser central avaliar a necessidade de agrupamento de propriedades e de uso de infraestrutura física, gerencial e institucional já existentes para viabilizar a REDD. Tal ação de agrupamento de diversos imóveis vem sendo desenvolvida com êxito no México (LIBERT AMICO; TRENCH, 2016).

No âmbito das primeiras ações de REDD, as chamadas "juntas intermunicipais" surgiram como um novo modelo de governança territorial. Estas reuniões propõem a coordenação de vários municípios ou áreas em torno de projetos específicos, seja para a gestão de resíduos sólidos, a gestão de uma bacia ou gestão de programas REDD. A primeira junta intermunicipal a ser consolidado neste marco foi o "Conselho Intermunicipal de Meio Ambiente para a Gestão Integral da Bacia do Baixo Rio Ayuquila" (JIRA), formado em 2007, na bacia inferior do rio Ayuquila de Jalisco (LIBERT AMICO; TRENCH, 2016).

A adoção do modelo de juntas intermunicipais responde não apenas à influência de determinados indivíduos que participaram do desenho do programa na época, mas também a 
uma exigência legal e administrativa, tendo como objetivo otimizar recursos com a estrutura existente. A figura legal das juntas intermunicipais permite receber recursos, públicos ou privados, e implementar programas nos imóveis (VILLA et al., 2017). No Brasil, existe uma figura que guarda semelhanças com as juntas que são os chamados consórcios públicos (Lei Federal $n^{\circ}$ 11.107/2005) em que participam apenas os entes federativos (União, Estados, Municípios e Distrito Federal). Contudo, na esfera do meio ambiente, eles atuam preponderantemente na gestão de resíduos sólidos tendo em vista sua previsão expressa na Política Nacional de Resíduos Sólidos (Lei Federal 12.305/10).

Existe um consenso de que as áreas que se tem a intenção de preservar são mais eficazmente conservadas quando são bem apoiadas pelos residentes locais; portanto, os planos de conservação nessas áreas vêm considerando cada vez mais as áreas protegidas como sistemas humano-naturais integrados (ANGELSEN et al., 2018).

Vários autores coincidem em apontar a transição atual de uma governança "antiga" centrada em um governo hierárquico e unidirecional, para uma "nova" governança multidirecional, que inclui uma variedade de atores, tanto sociais quanto econômicos e transnacionais locais, operando em diferentes escalas ou níveis. As provas de sucesso do Acre e Mato Grosso na modelo REDD são exemplos nessa atuação (NEPSTAD et al., 2018; DAWSON et al., 2018).

No campo da governança ambiental, pode-se ver como diferentes atores do governo, do mercado e da sociedade civil influenciam e interagem para produzir resultados ambientais - positivos e negativos. Em poucas palavras, depois de uma mudança em uma paisagem, como o desmatamento, o reflorestamento ou a semeadura de uma nova safra, quem ganhou e quem perdeu?

Caberia, pois, no contexto da Caatinga de Pernambuco criar, assim como existe de maneira similar no bioma amazônico, o chamado Plano de Prevenção e Controle do Desmatamento na Caatinga (PPCDCaa), concebido para guiar ações multisetoriais no combate ao desmatamento, estabelecendo prioridades e fomentando o diálogo com outras iniciativas complementares.

Na Floresta Amazônica, este plano, conhecido como PPCDAm, definiu estratégias para as seguintes áreas: monitoramento e controle ambiental; ordenamento fundiário e territorial; e fomento às atividades produtivas sustentáveis. O PPCDAm prevê iniciativas em sintonia com as metas da REDD, da economia regional, com o Plano Amazônia Sustentável (PAS 2008), com a Política Nacional sobre Mudanças do Clima (Lei n. 12.187/2009) e com o Fundo Amazônia (NEPSTAD et al., 2018). 
Iniciativas como a maior abrangência das áreas receptoras, a identificação das principais causas responsáveis pelo desmatamento na Caatinga pernambucana, assim como a integração com outras políticas não só ambientais mas também de desenvolvimento econômico, poderiam levar Pernambuco a seguir os exemplos de sucesso obtido pelo Acre e Mato Grosso, criando um ambiente mais propicio para efetivação a REDD no Estado.

\subsubsection{Beneficiários: direitos do carbono}

O modo como foi descrita a REDD no ordenamento pernambucano poucos seriam os beneficiados com os chamados direitos do carbono. Esse argumento tem validade em razão do perfil escolhido para as áreas receptoras. RPPNs, via de regra, não são ligadas a grupos ou pessoas com baixo poder aquisitivo, bem como propriedades que excedam os limites de RLs e APPs juntamente com o registro de servidões ambientais em sua matrícula no cartório de imóveis. Excluindo os espaços como as pequenas propriedades rurais e os assentamentos o Poder Público deixa de agregar valor à sua oferta de carbono.

De acordo com Furlan (2010), a preservação da integridade do ecossistema atrelada à promoção do desenvolvimento sustentável local é um grande desafio para a estratégia de mitigação e, também, para a manutenção do equilíbrio ecológico na região. Os diferentes padrões nos níveis de desenvolvimento na Caatinga devem ser continuamente explorados, oferecendo suporte para políticas públicas que visem a promoção da sustentabilidade e a redução do desmatamento na região (REIS NETO et al., 2018).

Para tanto, dependendo dos objetivos do projeto, diferentes fatores e processos precisam ser monitorados: variáveis ambientais (por exemplo, mudanças na cobertura florestal/ vegetal, biodiversidade, solo, água e clima); sistemas de produção (por exemplo, dados sobre rendimento, formas de plantio, manejo da vegetação nativa); e variáveis socioeconômicas (por exemplo, segurança alimentar, renda familiar e igualdade de gênero) (PETERSEN et al., 2018).

De acordo com Nascimento (2015), em estudo feito com uma amostra de 68 munícipios do Agreste e do Sertão pernambucano, nas áreas estudadas, por meio de técnicas de sensoriamento remoto, os espaços com vegetação nativa correspondem à 2.292.627,9 ha, $\mathrm{o}$ que equivale à $64.671 .848,6 \mathrm{Mg}$ relativos ao estoque de biomassa de carbono (NASCIMENTO, 2015). Os preços de 1 tonelada de $\mathrm{CO}_{2}$, que equivale a 1 crédito de carbono, variam muito no mercado financeiro (LANA, 2017) a depender da metodologia da certificação adotada bem como outros elementos agregados como preservação ambiental da 
área, participação e gestão democrática assim como a redução da pobreza dos beneficiários. Existem créditos vendidos de US\$ 0,65/tCO 2 a US\$ 50/tCO 2 (LANA, 2017).

Segundo Lana (2017), a análise econômica mostra que os projetos de PSA-Carbono são mais atrativos economicamente do que a produção de lenha em áreas pequenas na Caatinga pernambucana, mas em áreas maiores devido à baixa remuneração da mão de obra na exploração da lenha os Planos de Manejo Florestal se destacam. Todavia, existe um potencial inexplorável de sumidouro de carbono na Caatinga, devendo ser aproveitado tanto em projetos de pequena como de média escala no plano estadual e nacional (MORAIS et al., 2017; LANA, 2017).

O carbono pode ser considerado como uma nova forma de propriedade nos ecossistemas florestais que tem valor potencial devido à criação de novos mercados e fundos destinados a reduzir as emissões de carbono ou melhorar as remoções (UN-REDD 2018; CLIMATE INVESTMENT FUNDS, 2018). Isso levanta questões legais em torno de como os direitos do carbono, como a propriedade, e os direitos associados de transferir/comercializar são determinados.

Nesse segmento, os denominados "direitos do carbono" definem quais partes têm o direito de vender, comercializar e comprar um crédito de carbono (ou seja, uma quantidade fixa de carbono) nos mercados voluntários e obrigatórios do mundo, ou através de acordos bilaterais. Os direitos de carbono podem estar ligados à propriedade ou controle sobre a terra e as árvores. Alternativamente, eles podem ser definidos como ativos autônomos e intangíveis com um valor monetário - semelhante a um direito de propriedade intelectual, marca de uma empresa ou título de hipoteca (UN-REDD 2018).

Novos recursos, como o carbono, que está associado a novos esquemas de redução de emissões, como a REDD, ainda não foram abordados adequadamente pelas leis brasileiras, apesar da existência do Código Civil que trata de maneira geral dos bens. Em muitos casos, as regulamentações florestais dificultam que as comunidades e os governos estaduais se beneficiem de recursos valiosos sem substancial apoio externo. Todavia, isso não impede que iniciativas como a do Acre e Mato Grosso prosperem (NEPSTAD et al., 2018).

Não existe uma definição operacional única de "direitos de carbono" no nível internacional e pouquíssimos países adotaram definições em seus sistemas jurídicos nacionais. Portanto, os direitos do carbono só podem ser definidos amplamente como ativos intangíveis criados por arranjos legislativos e contratuais que permitem o reconhecimento de benefícios separados decorrentes do sequestro de carbono na biomassa (UN-REDD 2018; CLIMATE INVESTMENT FUNDS, 2018). 
O carbono armazenado é, portanto, uma propriedade autônoma independente da biomassa física; o direito comercializável é criado em virtude de arranjos legislativos e/ou contratuais. O termo "direitos de carbono" contém dois conceitos fundamentais: 1) os direitos de propriedade do carbono sequestrado em si (mas contidos em terra, árvores, solo, etc.); e 2) os direitos aos benefícios que resultam da transferência desses direitos de propriedade, por exemplo, através de esquemas de comércio de emissões (NORWEGIAN CLIMATE AND FOREST INITIATIVE, 2017).

A fim de entender os direitos de carbono, é importante entender a natureza do carbono como propriedade (ou seja, o que está sendo possuído; quem pode possuir qual dos direitos de propriedade em carbono; e quem tem direitos sobre os benefícios) e também o derivativo que são direitos associados à negociação (como a integração de propriedades individuais em regimes nacionais ou internacionais da REDD resulta em benefícios; e quais são os processos e responsabilidades associados a isso).

Essa lacuna não existe apenas no cenário brasileiro. No México, no contexto da implementação da REDD, ainda existem algumas contradições e ambiguidades legais, especialmente no que diz respeito à propriedade do carbono e o direito de se beneficiar de emissões evitadas. Mas, segundo Libert Amico e Trench (2016) nenhuma disposição legal no México indica expressamente quem tem direito à propriedade sobre o carbono florestal.

Experiência com outros sistemas indicam que tanto a teoria quanto as evidências sugerem que o potencial de ganhos ambientais e de alívio da pobreza depende de áreas com alto risco de perda ambiental serem de propriedade de famílias pobres e se os valores de pagamento são suficientemente grandes para compensar os custos de oportunidade e participação (NEUDERT et al., 2018; NEPSTAD et al., 2018). O carbono pode, nesse cenário, aliviar as pressões antrópicas no meio ambiente, incrementando a renda das comunidades desde que exista o reconhecimento desses direitos ligados ao carbono por parte do ordenamento legal, seja nacional ou internacional.

No Quênia, em estudo coordenado por Angelsen et al (2018), a pesquisa revelou que esses benefícios não correspondiam às expectativas locais ou compensaram os custos de oportunidade de restringir o uso da floresta. É importante destacar que o fracasso de muitos projetos da REDD de fornecer benefícios locais - incluindo perspectivas de substanciais transferências de renda que nunca se materializaram devido à falta de financiamento previsível - levou a frustrações e a dúvidas quanto à REDD (SALLET et al., 2018; VIANA, 2009). Cabe destacar que para além da questão econômica, as mudanças culturais das comunidades envolvidas devem ser levadas em consideração tendo em vista que não se pode 
unicamente valorar seus modos de interação com o meio ambiente, transformando-os em meros cálculos econômicos. Nesse sentido, a educação ambiental é instrumento fundamental para o sucesso da REDD junto às populações (UN-REDD, 2018; ANGELSEN et al., 2018).

Uma recente revisão de literatura indicou que os fornecedores de serviços ambientais contratados (aqueles que recebem os pagamentos) normalmente obtêm rendimentos mais altos como resultado da participação em PSAs, mas há pouca evidência disponível sobre os impactos não monetários (ANGELSEN et al., 2018). Umunay et al. (2018) demonstraram o potencial do PSA em condições ideais (ou seja, implementação no contexto de alto desmatamento e baixos custos de oportunidade), mostrando que ele pode reduzir o desmatamento sem impor um custo de redução da qualidade de vida aos usuários florestais locais.

A participação das comunidades residentes na Caatinga não é garantia efetiva de redução do desmatamento na região. Contudo, a exclusão destes no desenvolvimento dos direitos do carbono por parte do legislador pernambucano traz reflexões sobre em que medida o Estado está inserido nas principais discussões climáticas, tendo em vista o entendimento consensual por parte dos principais financiadores de fundos públicos e privados que quanto maior for a inserção de atores locais maior é a probabilidade de obtenção dos recursos.

Ao fim da análise, pode-se visualizar de maneira resumida, por meio do Quadro 1, utilizando-se do método comparativo (DUTRA, 2016; MARRARA, 2014; DANTAS, 2012), quais são as principais características encontradas na legislação da REDD em Pernambuco, Acre e Mato Grosso, em relação aos critérios de financiamento, áreas receptoras e beneficiários.

Quadro 1 - Características da REDD em Pernambuco, Acre e Mato Grosso

\begin{tabular}{|c|c|c|c|}
\hline \multirow{2}{*}{ LEGISLAÇÃO ESTADUAL } & \multicolumn{3}{|c|}{ CARACTERISTICAS } \\
\hline & FINANCIAMENTO & ÁREAS RECEPTORAS & BENEFICIÁRIOS \\
\hline Pernambuco (Lei 15.809/16) & Público & $\begin{array}{c}\text { RPPNs; Excedentes de APP e RL; Servidão } \\
\text { Ambiental. }\end{array}$ & $\begin{array}{c}\text { Particulares (via de regra } \\
\text { imóveis com grandes extensôes) }\end{array}$ \\
\hline Mato Grosso (Lei 9.878/13) & Público/Privado & $\begin{array}{l}\text { (I) unidades de conservação legalmente instituídas; } \\
\text { (II) terras indígenas; (III) territórios quilombolas; } \\
\text { (IV) outras áreas legitimamente ocupadas por } \\
\text { populações tradicionais; (V) assentamentos rurais } \\
\text { da reforma agrária; (VI) propriedades e posses rurais } \\
\text { de domínio privado; (VII) - outros imóveis rurais de } \\
\text { domínio público }\end{array}$ & $\begin{array}{c}\text { Particulares (pequenas e } \\
\text { grandes extensões); Poder } \\
\text { público }\end{array}$ \\
\hline Acre (Lei $2.308 / 10$ ) & Público/Privado & $\begin{array}{c}\text { (I) unidades de conservação legalmente instituídas; } \\
\text { (II) terras indígenas; (III) territórios quilombolas; } \\
\text { (IV) outras áreas legitimamente ocupadas por } \\
\text { populações tradicionais; (V) assentamentos rurais } \\
\text { da reforma agrária; (VI) propriedades e posses rurais } \\
\text { de domínio privado; (VII) - outros imóveis rurais de } \\
\text { domínio público }\end{array}$ & $\begin{array}{c}\text { Particulares (pequenas e } \\
\text { grandes extensôes); Poder } \\
\text { público }\end{array}$ \\
\hline
\end{tabular}

Fonte: Elaborado pelo autor com base nos dados contidos em Pernambuco (2016), Mato Grosso (2013), Acre (2010). 


\subsection{SALVAGUARDAS REDD: PERNAMBUCO}

Com a criação da PEPSA (Lei Estadual n 15.809/2016), Pernambuco criou seu marco legal para o desenvolvimento dos pagamentos por serviços ambientais (PSA), sendo pioneiro nessa temática na região Nordeste. Entre as diversas modalidades de PSAs previstos na legislação pernambucana chama atenção a REDD (PERNAMBUCO, 2016). Apesar de suas discussões internacionais datarem do início do século XXI, ela ainda não tinha respaldo legal para sua implementação. Nessa perspectiva, em âmbito nacional, ainda existe uma lacuna normativa, que, contudo, não impediu que Estados como Acre, Amazonas e Pará (AMARANTE; RUIVO, 2013), além de Pernambuco, disciplinassem a matéria.

Com o objetivo de instrumentalizar a aplicação dos PSAs, a PEPSA trouxe em seu escopo uma lista de salvaguardas que devem ser observadas na composição dos projetos, inclusive a REDD. Essas salvaguardas podem ser observadas na Figura 8:

Figura 8 - Salvaguardas da PEPSA

\begin{tabular}{|c|c|}
\hline \multicolumn{2}{|r|}{ SALVAGUARDAS DA PEPSA (Art. 4ㅇ) } \\
\hline I & reconhecimento e respeito aos direitos de posse e uso de terra, territórios e recursos naturais \\
\hline II & sustentabilidade econômica compatível com a melhoria da qualidade de vida e redução da pobreza \\
\hline III & $\begin{array}{l}\text { utilização racional dos recursos naturais através de técnicas de manejo sustentável que assegurem a } \\
\text { proteção e integridade do sistema climático em benefício das presentes e futuras gerações }\end{array}$ \\
\hline IV & $\begin{array}{l}\text { respeito aos conhecimentos e direitos dos povos e comunidades tradicionais e extrativistas, bem como aos } \\
\text { direitos humanos reconhecidos e assumidos pelo Estado brasileiro perante a ONU e demais compromissos } \\
\text { internacionais, incorporando-os às práticas de PSA, quando cabível }\end{array}$ \\
\hline V & $\begin{array}{l}\text { incorporação às iniciativas de PSA, sempre que possível, de ações educativas, fornecimento de assistência } \\
\text { técnica e extensão rural, por meio de orientações e assessoria na elaboração, execução e/ou } \\
\text { monitoramento de projetos de PSA }\end{array}$ \\
\hline VI & $\begin{array}{c}\text { justiça e equidade na repartição dos benefícios econômicos e sociais oriundos dos produtos e serviços } \\
\text { vinculados aos pagamentos associados a esta Lei }\end{array}$ \\
\hline VII & $\begin{array}{l}\text { transparência, eficiência e efetividade na administração dos recursos financeiros, com participação social } \\
\text { na sua aplicação, gestão e monitoramento }\end{array}$ \\
\hline VIII & $\begin{array}{c}\text { monitoramento e transparência na elaboração, processos decisórios e implementação de iniciativas, } \\
\text { programas e projetos de PSA, garantindo-se disponibilidade plena de acesso às informações, participação } \\
\text { e controle social }\end{array}$ \\
\hline IX & $\begin{array}{c}\text { adoção do princípio do provedor-recebedor que defende a garantia de recompensa ao provedor de serviços } \\
\text { ambientais pela manutenção, recuperação ou melhoria desses serviços, apoiando-o na elaboração, } \\
\text { execução e/ou monitoramento de projetos técnicos }\end{array}$ \\
\hline$X$ & $\begin{array}{l}\text { integração desta Lei às diretrizes e instrumentos da Política de Reforma Agrária (Lei Federal no } \\
\text { 8.629/1983); Política Agrícola (Lei Federal no 8.171/1991); Política Estadual de Meio Ambiente (Lei no } \\
\text { 14.249/2010); de Recursos Hídricos (Lei no 12.984/2005); de Combate à Desertificação e Mitigação dos } \\
\text { Efeitos da Seca (Lei no 14.091/2010); de Enfrentamento às Mudanças Climáticas (Lei no 14.090/2010); de } \\
\text { Convivência com o Semiárido (Lei no 14.922/2013); e à Lei no 13.787/2009, que cria o Sistema Estadual de } \\
\text { Unidades de Conservação da Natureza - SEUC }\end{array}$ \\
\hline
\end{tabular}

Fonte: Elaborada pelo autor, com base em Pernambuco (2016). 
Em uma breve leitura das salvaguardas, observa-se a preocupação com a simetria das proposições previstas nos Acordos Internacionais, principalmente a denominada “Salvaguardas de Cancún". Conceitos de transparência, participação, direitos de posse e controle social são reiterados (PERNAMBUCO, 2016). Contudo, cabe uma observação crítica que antecede até mesmo a disposição das salvaguardas na PEPSA. O texto do Art. $4^{\circ}$ é bastante claro, não deixando grandes lacunas para explicação e os incisos são autoexplicativos, ponto positivo que deve ser ressaltado. Contudo, a observação que deve ser feita reside no conteúdo de cada salvaguarda que é o verdadeiro objetivo dessa análise. O espaço reservado na PEPSA poderia ser utilizado para elaboração de salvaguardas mais concretas, de caráter impulsor bem como as mitigativas. O resultado da análise (Figura 9), entretanto, mostra uma verdadeira preponderância de salvaguardas principiológicas.

Figura 9 - Análise das Salvaguardas presentes PEPSA pela metodologia RSS Framework

\begin{tabular}{|c|c|c|c|c|}
\hline $\begin{array}{c}\text { Art 40 da } \\
\text { PEPSA }\end{array}$ & $\begin{array}{c}\text { Salvaguardas } \\
\text { Principiológicas }\end{array}$ & $\begin{array}{c}\text { Salvaguardas } \\
\text { Preventivas }\end{array}$ & $\begin{array}{c}\text { Salvaguardas } \\
\text { Mitigativas }\end{array}$ & $\begin{array}{c}\text { Salvaguardas } \\
\text { Impulsoras }\end{array}$ \\
\hline I & & & & \\
\hline II & & & & \\
\hline III & & & & \\
\hline IV & & & & \\
\hline V & & & & \\
\hline VI & VII & & & \\
\hline VIII & & & & \\
\hline IX & & & & \\
\hline X & & & \\
\hline \hline
\end{tabular}

Fonte: Elaborado pelo autor.

A crítica reverbera ainda mais quando se verifica que as salvaguardas principiológicas (num total de quatro) trazem em seu conteúdo a mesma essência apresentada nas “Salvaguardas de Cancún”. Mesmo as salvaguardas impulsoras, que são revestidas de maior concretude (ARHIN, 2014) na aplicação, carecem da explicitação do modo como serão monitorados e efetivadas. Essa ausência não apenas se verifica no Art. $4^{\circ}$, mas em toda a PEPSA não fica claro o modo como as salvaguardas serão aplicadas e acompanhadas.

Cabe destacar que a análise identificou nas salvaguardas: quatro (4) principiológicas; duas (2) preventivas; uma (1) mitigativa; e quatro (4) impulsoras. Em relação à identificada como mitigativa, ela apresenta traços de impulsora. Por essa razão, é considerada uma salvaguarda mista/híbrida, sendo contabilizada nas duas classes. Os dados obtidos são um 
verdadeiro retrato da legislação ambiental brasileira em que existe primazia pelos princípios e normas abertas.

De acordo com Streck (2012), essa utilização em excesso dos princípios faz com esses sirvam apenas como "amarras interpretativas”, esvaziando seu real valor. Os princípios devem ser entendidos por meio de seu caráter normativo, não podendo ter mero papel retóricocorretivo, tampouco ser entendidos como mandados de otimização, recheados de predicados.

Essa característica não é exclusiva da legislação ambiental. A enorme influência da teoria dos princípios na própria Constituição e mesmo nas sentenças do Supremo Tribunal Federal é algo autoevidente. Ferrajoli (2012) já havia alertado para a consequência dessa utilização em excesso:

[...] terminou se transformando, nestes últimos anos, em uma espécie de bolha terminológica, tão dilatada que chegou às formas mais variadas de esvaziamento e de inaplicação das normas constitucionais e infraconstitucionais, tanto no nível legislativo quanto no nível jurisdicional. (FERRAJOLI, 2012, p. 47).

Sundfeld (2012) chegou a afirmar que princípios em demasia são como "armas de espertos e de preguiçosos", ante a comodidade que oferecem aos legisladores e hermeneutas, na medida em que ocultam a fragilidade argumentativa de direitos invocados com base em princípios ocos de expressão normativa para determinados casos.

Nesse sentido, não é equivocado afirmar que o espaço dedicado as salvaguardas principiológicas poderia ser melhor utilizado com a previsão da obrigatoriedade da regularização fundiária das áreas que desejam implementar a REDD por parte do órgão financiador; a previsão expressa de uma ouvidoria para eventuais problemas decorrentes do processo de implementação; a definição de indicadores de monitoramento das salvaguardas (renda da comunidade, acesso à educação, aumento da regeneração natural da área) e até mesmo um Sistema Estadual de Informações, no qual seriam compilados desde informações de cunho financeiro (contratos, percentuais de emissões evitados, dados dos fornecedores) até questões sociais.

Apesar destas características, não há impedimento quanto à implementação da REDD, tornando-se apenas mais complexo o processo de verificação no cumprimento dessas salvaguardas e, por conseguinte, a sua plena efetividade (CHACÓN, 2016). Por exemplo, de que maneira poderá ser verificado se está ocorrendo "a justiça e equidade na repartição dos benefícios".

De outra forma, as salvaguardas preventivas, apesar de serem apenas duas (2), estão bem exemplificadas pelo seu essencial que é o reconhecimento dos direitos das comunidades. 
Esse é uma salvaguarda que pode ser extraída de um dos sete princípios de Cancún ${ }^{6}$, todavia a PEPSA trouxe o texto de maneira mais clara e objetiva, facilitando a compreensão.

Em relação a salvaguarda mitigativa cabe um alerta. Conforme dito anteriormente, essas possuem como objetivo minimizar o impacto negativo da REDD sobre as comunidades locais e seus meios de subsistência (ARHIN, 2014). Trazer apenas uma (1) mitigativa é quase como assumir que não haverá problemas decorrentes da implementação a serem minimizados. Nesse sentido, seria salutar a previsão de compensações (financeiras ou por meio de projetos) para as comunidades, e de reassentamento de comunidades (total ou parcial) para melhor gerenciamento do instrumento, dentre outros (NEUDERT, 2018).

Deste modo, apesar do Art. $4^{\circ}$ PEPSA apresentar lacunas que necessitam de um aperfeiçoamento, essas não chegam a inviabilizar a efetivação da REDD. Contudo, seria necessária a definição de alguma forma de controle e acompanhamento da aplicação, tendo em visto que com assim seria possível avaliar "la existencia de capacidad técnica, institucional y presupuesto suficiente para su efectiva aplicación”(CHACÓN, 2016, p.44).

${ }^{6}$ (III) Respeito pelo conhecimento e direitos dos povos indígenas e membros de comunidades locais (...) (UNFCCC, 2015). 


\section{CONCLUSÃO}

Pernambuco, por meio dos seus órgãos governamentais, criou um ambiente jurídico adequado para a promoção de instrumentos legais que possuem como objetivo a mitigação dos efeitos das mudanças climáticas. Essa base, de acordo com a lógica do desenvolvimento sustentável, deve ser a proteção ao meio ambiente e as engrenagens flexíveis/adaptáveis são os instrumentos que protegem e promovem os aspectos sociais e econômicos de maneira harmônica e sistêmica.

Essa função é atribuída à Redução do Desmatamento e da Degradação Florestal (REDD) tendo em vista todo o arcabouço jurídico legal desenvolvido para sua implementação no Estado. Desde a definição de objetivos até a criação de um arranjo institucional favorável, esse sistema vem ocupar uma lacuna existente não só no plano legal, mas também na realidade que outrora era caracterizada pela falta de eficácia dos instrumentos de comando e controle.

Posto esse cenário, a REDD, bem como a própria Política Estadual de Enfretamento às Mudanças Climáticas (PEEMC) e a Política Estadual de Pagamentos por Serviços Ambientais (PEPSA), despontam como ferramentas que são teoricamente simétricas com os princípios ambientais que iluminam o direito brasileiro sendo conexas com as propostas globais de ação no campo ambiental. Seus fundamentos têm por base não só as disposições legais estaduais, mas também as diretrizes nacionais e convenções/tratados internacionais. Logo, sob o ponto de vista jurídico, a REDD pode ser implementada em Pernambuco para conservação da Caatinga. Contudo, a definição dos critérios concebidos pelo legislador estadual traz dificuldades de implementação que vão desde o financiamento dos projetos até a identificação das áreas potenciais, perpassando pela definição dos possíveis beneficiários.

As contribuições da comunidade internacional e a atuação dos diferentes níveis de Governo na região da Caatinga devem avançar na promoção da integração entre políticas setoriais econômicas e as leis ambientais para garantir a criação de um ciclo de conservação duradouro. A atuação conjunta entre Poder Público, população e setor privado podem ser a chave para a integração tão necessária entre meio ambiente-sociedade na realidade desafiadora do bioma.

O desenvolvimento de instrumentos econômicos como a REDD mostra-se como uma complementação da política ambiental brasileira e, mais especificamente, as estratégias ambientais traçadas por Pernambuco. A situação fragilizada tanto sobre o ponto de vista 
biológico quanto social favorecem uma mudança de postura na condução do programa estadual de gestão dos recursos naturais.

Nesse sentido, com a edição da Lei Estadual nº 15.809/2016 Pernambuco avançou nessa temática. Todavia, o programa pernambucano apresenta algumas lacunas como a falta de uma atuação mais incisiva no mercado de carbono, principalmente como fomentador dessa nova realidade que se apresenta, o que implica diretamente na dificuldade de captação do interesse dos fundos públicos e principalmente no setor privado. Assumir essa falta de competitividade e criar um verdadeiro sistema REDD é fundamental para atrair recursos. No Brasil, contudo, já há condições favoráveis para que isto ocorra como é o caso do Acre e do Mato Grosso.

A diferença no patamar de desenvolvimento de Pernambuco torna-se ainda maior quando comparada aos sistemas estaduais consolidados internacionalmente como do Acre (Lei Estadual n 2.308/10) e do Mato Grosso (Lei Estadual n 9.878/13). Fatores que explicam o sucesso dos dois casos implantados, até o presente momento, são a integração com as atividades econômicas realizadas nos Estados (adaptação ao contexto local), inclusão de diversidade de áreas receptoras e, consequente, reconhecimento dos direitos do carbono.

No caso pernambucano, o número reduzido de áreas receptoras definidos pela lei estadual, bem como as espécies (RPPNs, RLs e APPs excedentes, e servidão florestal) reduzem consideravelmente o potencial de expansão da REDD, bem como o afastamento de maior participação das comunidades locais, dificultando esse modelo ideal de financiamento (misto, público e privado). Da mesma forma, a não inclusão dos assentamentos rurais presentes na Caatinga se mostra, sob o ponto de vista de disponibilidade espacial, equivocada pois poder-se-ia adotar o esquema de juntas intermunicipais (modelo próximo aos consórcios públicos no Brasil) ou outro modelo que integram esses espaços à REDD.

Com a delimitação dos principais requisitos para implementação, o instrumento começou, no plano global, a ser posto em prática, acarretando uma série de críticas, principalmente de cunho social, consubstanciadas no desrespeito aos direitos (propriedade das terras e uso dos recursos) das comunidades que se utilizam dos remanescentes para sua subsistência. Buscando remediar o referido quadro, foram propostas salvaguardas para proteger as populações que são diretamente afetadas por essas iniciativas.

Apesar do seu protagonismo em relação as discussões climáticas, o Brasil ainda não disciplinou a REDD em sua legislação ambiental. Isso não impediu que Pernambuco definisse requisitos e critérios para sua efetivação. Todavia, as salvaguardas propostas, em sua maioria, são baseadas em princípios gerais, o que dificulta a sua implementação. 
Com base na metodologia RSS Framework, a presente análise encontrou um grande número de salvaguardas principiológicas (4) e poucas salvaguardas mitigativas (1). Nesse sentido, a ação ideal seria a reformulação das salvaguardas propostas, principalmente a redução das principiológicas e o aumento das mitigativas. No entanto, a referida ação, em razão do processo legislativo, pode ser uma iniciativa a médio/longo prazo.

A definição de indicadores de monitoramento para as salvaguardas (renda da comunidade, acesso à educação, aumento da regeneração natural da área) e até mesmo um Sistema Estadual de Informações na qual seriam compilados desde informações de cunho financeiro (contratos, percentuais de emissões evitados, dados dos fornecedores) até questões sociais são proposições que podem facilitar o monitoramento do instrumento.

Cabe ressaltar a recomendação que estudos futuros mais aprofundados nessa temática são fundamentais para consolidação da REDD no cenário de Pernambuco, tanto no aspecto das bases legais quanto nos elementos socioambientais da Caatinga. Nesse sentido, a implementação do instrumento não é uma fórmula que possui um resultado predefinido e sim um fluxo contínuo de conhecimentos que convergem para a melhoria da qualidade ambiental do ecossistema. 


\section{REFERÊNCIAS}

ACRE. Lei N. 2.308, de 22 de outubro de 2010. Cria o Sistema Estadual de Incentivos a Serviços Ambientais - SISA, o Programa de Incentivos por Serviços Ambientais - ISA Carbono e demais Programas de Serviços Ambientais e Produtos Ecossistêmicos do Estado do Acre. Disponível: < http://www.al.ac.leg.br/leis/wpcontent/uploads/2014/09/Lei2308.pdf>. Acesso em: Mar. de 2019.

AMARANTE, C. B.; RUIVO, M. L. P. A política ambiental à luz da Convenção sobre Mudanças Climáticas: uma análise da implementação jurídiconormativa do REDD no Pará. In: Novos Cadernos NAEA, v.16, p.67-96, 2013.

AMORIM, Fernando Sérgio Tenório de; BARROS, Hugo Marinho Emídio de. Dignidade Humana, Segurança Nacional e os Refugiados Ambientais na Lei 9.474/1997. In: Revista Veredas do Direito, v. 14, n. 28, p. 93-126, jan./abr. 2017.

ANGELSEN, A. (ed.). Moving ahead with REDD: Issues, options and implications. Bogor, Indonesia: CIFOR, 2008.

ANGELSEN, A., BROCKHAUS, M., SUNDERLIN, W.D. (eds). Analysing REDD+: Challenges and choices. Bogor: CIFOR, 2012.

ANGELSEN, A.; MARTIUS C.; DE SY, V.; DUCHELLE A.E, LARSON A.M; PHAM T.T. Transforming REDD+: Lessons and new directions. Bogor: CIFOR, 2018.

ANGELSEN, A. SUNDERLIN, W. D. (eds.) Realising REDD+: national strategy and policy options. Bogor, Indonesia, CIFOR, 2009.

ARHIN, A. A. Safeguards and dangerguards: A framework for unpacking the black box. In: Forest Policy and Economics, vol. 45, p.24-31, 2014.

BNDES. Relatório de Atividades 2013 - Fundo Amazônia. Banco Nacional do Desenvolvimento, jun. 2014. Disponível em:

<http://www.fundoamazonia.gov.br/FundoAmazonia/export/sites/default/site_pt/Galerias/Arq uivos/Relatorio_Anual/RAFA_virtual_PORT_2013.pdf>. Acesso em: 02 jan. 2019.

BRASIL. Constituição Federal da República Federativa do Brasil de 1988. Disponível em <https://www.planalto.gov.br/ccivil_03/constituicao/ConstituicaoCompilado.htm> . Acesso em 18 de fev. de 2017

CHACÓN, M.P.; El camino hacia la efectividad del derecho ambiental. In: Innovare, vol.5, n.1, p.34-48, 2016. 
CLIMATE INVESTMENT FUNDS. FIP Operations and Results Report. Disponível em: $\langle$ https://www.climateinvestmentfunds.org/sites/cif_enc/files/fip_19_3_orr_1.pdf $>$. Acesso em: Jan de 2019.

CUNHA, T.F. O REDD como instrumento econômico de concretização do desenvolvimento sustentável na Amazônia brasileira. In: BENJAMIN, A.H.; LECEY, E.; IRIGARAY, C.T.S.H PNMA: 30 anos da Política Nacional de Meio Ambiente. São Paulo: Imprensa Oficial do Estado de São Paulo, 2011.

DANTAS, I. Novo curso de direito constitucional comparado: teoria, metodologia e prática. Curitiba: Juruá, 2012.

DAVIET, F.; LA LARSEN, G. Safeguarding forest and people: A framework for designing a national system to implement REDD+ safeguards. Berna: World Resources Institute, 2012.

DAWSON, N.M; MANSON, M; MWAYAFU, D.M; DHUNGANA, H. Barriers to equity in REDD+: Deficiencies in national interpretation processes constrain adaptation to context. In: Environmental Science and Policy, vol.88, p.1-9, 2018.

DUTRA, D.C. Método(s) em direito comparado. In: Revista da Faculdade de Direito UFPR, vol. 61, n. 3, p. 189-212, 2016.

ENREDD. National REDD+ Strategy of Brazil. Brasilia: Ministry of the Environment. 2016

FAO (Food and Agriculture Organization of the United Nations). Global Forest Resources Assessment 2016. Rome: FAO, 2016.

FERENCZY, M. A. V. H. Direito Ambiental: Potencial do REDD+ para a sustentabilidade. Curitiba: Juruá: 2012.

FERRAJOLI, L. Constitucionalismo principialista e constitucionalismo garantista. In: FERRAJOLI, L.; STRECK, L. L.; TRINDADE, A. K. (Org.). Garantismo, hermenêutica e (neo)constitucionalismo: um debate com Luigi Ferrajoli. Porto Alegre: Livraria do Advogado, 2012.

FIORILLO, C.A.P. Curso de Direito Ambiental Brasileiro. 15 ed. São Paulo: Saraiva, 2014.

FOREST CARBON PARTNERSHIP FACILITY. Forest Carbon Partnership Facility Annual 2017. Disponível em:

<https://www.forestcarbonpartnership.org/sites/fcp/files/2017/Sep/FCPF_Annual2017_web.p df>. Acesso em: Dez. de 2018.

FURLAN, M. Mudanças climáticas e valoração econômica da preservação ambiental. 0 pagamento por serviços ambientais e o princípio do protetor-recebedor. Curitiba: Juruá, 2010. 
GUANZIROLI, C.E; SABATTO, A.D; VIDAL M.F. Evolução da agricultura familiar nordestina: uma análise comparativa entre os dois censos agropecuários. Revista Econômica do Nordeste, p. 80-91, 2014.

GRAINGER, A.; OBERSTEINER, M. A framework for structuring the global forest monitoring landscape in the REDD+ era. In:Environmental Science \& Policy, v. 14, p. 127$139,2011$.

HAYES, T.; PERSHA, L. Nesting local forest initiatives: revisiting community forest management in a REDD+ world. In: Forest Policy and Economics, v. 12, n. 8, p. 545553,2010 .

HOSONUMA, N.; HEROLD, M.; DE SY, V.; DE FRIES, R.S.; BROCKHAUS, M.; VERCHOT, L.; ANGELSEN, A.; ROMIJN, E. An assessment of deforestation and forest degradation drivers in developing countries. In: Environmental. Restoration. vol. 7, 40-49, 2012.

IBGE. Síntese de indicadores sociais: uma análise das condições de vida da população brasileira. Rio de Janeiro: IBGE, 2010.

Síntese de indicadores sociais: uma análise das condições de vida da população brasileira, Coordenação de População e Indicadores Sociais, Estudos e pesquisas: Informação demográfica e socioeconômica 36. Rio de Janeiro: IBGE, 2016

ICMBIO. Sistemas de Informações Geográficas das Unidades de Conservação. Brasília: ICMBIO, 2017. Disponsível em: < http://sistemas.icmbio.gov.br/simrppn/publico/rppn/PE/> Acesso em: jan. 2019

INSTITUTO NACIONAL DE COLONIZAÇÃO E REFORMA AGRÁRIA - INCRA. Números da Reforma Agrária, 2016.

IRAWAN, S.; TACCONI, L. Reducing emissions from deforestation and forest degradation (REDD) and decentralized forest management. In: Forest, vol.11, p.427-438, 2013.

KAROUSAKIS, K. Promoting biodiversity co-benefits in REDD. Paris: OECD Environmental Working Papers. n.11, 2009.

KORHONEN-KURKI, K; BROCKHAUS, M; SEHRING, J; DI GREGORIO; M ASSEMBEMVONDO, S; BABON, A; BEKELE, M. What drives policy change for REDD+? A qualitative comparative analysis of the interplay between institutional and policy arena factors. In: Environmental Science and Policy, vol. 73, 61-70, 2018.

LANA, M. D. Carbono em vegetação lenhosa da caatinga e viabilidade econômica de manejo. Tese (Doutorado em Ciências Florestais) - Departamento de Ciências Florestais, Universidade Federal Rural de Pernambuco, Recife, 2017.

LIBERT AMICO, A.; TRENCH, T.. Bosques y suelos en el contexto de REDD+: Entre gobierno y gobernanza en México. In: Terra Latinoamericana, vol. 34, 113-124, 2016. 
MARRARA, T. Método comparativo e direito administrativo. In: Revista Jurídica UNIGRAN, vol. 16, n. 32, pg. 25-37, 2014.

MATHEUS, F.S. The role of forests and protected areas in climate change mitigation: a review and critique of the ecosystem services and REDD+ approaches. In: Desenvolvimento e Meio Ambiente, vol.46, p.23-36, 2018.

MATO GROSSO. Lei No 9878 DE 07 DE JANEIRO DE 2013. Cria o Sistema Estadual de Redução de Emissões por Desmatamento e Degradação Florestal, Conservação, Manejo Florestal Sustentável e Aumento dos Estoques de Carbono Florestal - REDD+ no Estado de Mato Grosso e dá outras providências. Disponível: < https://www.legisweb.com.br/legislacao/?id=249723 > . Acesso em: Jan. de 2019.

Estratégia Produzir, Conservar, e Incluir (PCI) em Mato Grosso. Bases

Para o Monitoramento Das Metas. Governo de Mato Grosso. Disponível em: $<$ https://produceprotectplatform.com/img/matogrosso/docs/Bases\%20para\%20o\%20Monitora mento\%20das\%20Metas\%20da\%20PCI_BR-EN.pdf>. Acesso em: Jan. de 2019.

MBATU, R. REDD+research: Reviewing the literature, limitations and ways forward. In: Forest Policy and Economics, vol.73, p.140-152, 2016.

MINISTÉRIO DO MEIO AMBIENTE (MMA). REDD + Relatório de painel técnico do MMA sobre financiamento, benefícios e cobenefícios. Brasília: MMA, 2015.

MILARÉ, É. Direito do Ambiente: Gestão Ambiental em foco. 8 ed. Rio de Janeiro: RT, 2013.

MORAIS, Y.C.B.M; ARAÚJO, M.S.B; MOURA, M.S.B.; GALVÍNCIO,J.D.; MIRANDA,R.Q. Análise do Sequestro de Carbono em áreas de Caatinga do Semiárido Pernambucano. In: Revista Brasileira de Meteorologia, v. 32, n. 4, p. 585-599, 2017.

NASCIMENTO, D. M. Estimativa do estoque de biomassa arbustivo arbórea por sensoriamento remoto em áreas de caatinga em Pernambuco. Dissertação (Mestrado em Tecnologias Energéticas e Nucleares) - Departamento de Energia Nuclear, Universidade Federal de Pernambuco, Recife, 2015.

NEPSTAD, D; STICKLER, C; CARVALHO, O; LEAL, M; SHIMADA, J; DAVID, O; RIBEIRO, A.The State of Jurisdictional Sustainability: Mato Grosso, Brazil. Bogor: Center for International Forestry Research (CIFOR), 2018.

NEUDERT, R; OLSCHOFSKY, K; KUBLER, D. Opportunity costs of conserving a dry tropical forest under REDD+: The case of the spiny dry forest in southwestern Madagascar. In: Forest Policy and Economics, vol. 95, p.102-114, 2018.

NORWEGIAN CLIMATE AND FOREST INITIATIVE (NICFI). Norad/Climate and Forest Initiative Funding Scheme for Civil Society 2013-2015: Guide to the Thematic Priority Areas. Disponível em: <https://www.norad.no/globalassets/import-2162015-80434am/www.norad.no-ny/filarkiv/3.-sivsa-2012---/cfi/guide-to-thematic-areas.pdf $\geq$. Acesso em: Jan. de 2019. 
NUSDEO, A.M. Pagamento por Serviços Ambientais: sustentabilidade e disciplina jurídica. São Paulo: Atlas, 2012.

OLESEN, A.; BÖTTCHER, H.; SIEMONS, A.; HERRMANN, L; MARTIUS, C. Study on EU Financing of REDD+ Related Activities, and Results-Based Payments Pre and Post 2020: Sources, Cost-Effectiveness and Fair Allocation of Incentives. Luxembourg: European Commission, DG Environment/Climate Action, 2018.

OST, F. The doctoral thesis in law: From the project to the defense. In: Revista de Estudos Constitucionais, Hermenêutica e Teoria do Direito, v. 7, n. 2, p. 98-116, mai./ago., 2015.

PAMELA J.; PUSHPENDRA R. Using publicly available social and spatial data to evaluate progress on REDD+ social safeguards in Indonesia. In: Environmental Science and Policy, vol.76, p.59-69, 2017.

PARKER, C. The Little REDD+ Book. Oxford: Global Canopy Foundation, 2009.

PERNAMBUCO. Lei $\mathbf{N}^{\circ} 14090$ de 2010. Dispõe sobre a Política Estadual de Enfrentamento a Mudanças Climáticas, e dá outras providências. Disponível:

<www.cprh.pe.gov.br/...PLANO_MC_PERNAMBUCO>. Acesso em: 18 de set. de 2017.

Lei Estadual 15.809/2016. Dispõe sobre Política Estadual de Pagamentos

por Serviços Ambientais (PEPSA), e dá outras providências. Disponível: <www.cprh.pe.gov.br/...PEPSA>. Acesso em: 02 de nov. de 2018.

Plano Estadual de Mudanças Climáticas. Recife: SEMAS, 2011.

REIS NETO, A.F.; SILVA, L.J.A.; ARAÚJO, M.S.B. Relatório de passivo ambiental: estudo de caso à luz da legislação, da doutrina e da jurisprudência ambientais brasileiras. Veredas do Direito, v. 13, n. 26, p. 141-166, mai./ago. 2016.

Mata Atlântica pernambucana: argumentos jurídicos para

implementação da R.E.D.D. Veredas do Direito, v. 14, n. 30, p. 143-168, set./dez. 2017.

Sistema Jurídico da REDD na Caatinga pernambucana. In: Veredas do

Direito, v.15, n.33, p.291-319, 2018.

RIBEIRO, E.M.S; ARROYO-RODRÍGUEZ, V., SANTOS, B.A, TABARELLI M, LEAL, I.R. Chronic anthropogenic disturbance drives the biological impoverishment of the Brazilian Caatinga vegetation. In: Applied Ecology, vol. 52, p.611-620, 2015.

SATHLER, B.; ADAMO, S.B; LIMA, E. Mudanças climáticas e mitigação no setor florestal: REDD+, políticas nacionais e desenvolvimento sustentável local na Amazônia Legal. Revista Bras. de Est. Populacional, v.32, n.3, p.619-630, set./dez. 2015. 
SALLES,G. P., SALINAS, D. T. P., PAULINO S. R. How Funding Source Influences the Form of REDD+Initiatives: The Case of Market Versus Public Funds in Brazil. In: Ecological Economics, vol. 139, 91-101, 2018

Execução de Projetos de REDD+ no Brasil por meio de diferentes modalidades de financiamento. In: Revista de Economia e Sociologia Rural, Vol. 55, No 03, p. 445-464, 2017.

SARLET, I. W. A eficácia dos direitos fundamentais. 9. ed. Porto Alegre: Livraria do Advogado, 2007.

SILVA, C. E. M., CRUZ NETO, C. C., NOGUEIRA; J. M., LIMA; L. C. L., BEZERRA, A. C. V., BENTO-SILVA, J. S. Conservation Unit System: Costs and Expenditures to Maintain the Natural Capital. An Evaluation of the State of Pernambuco's Reality. In: Revista Brasileira de Geografia Física, v.11, n.2, 661-673, 2018.

SILVA, J.M.C; LEAL, I.R.; TABARELLI, M. Caatinga: The Largest Tropical Dry Forest Region in South America. Gewerbestrasse: Springer, 2017.

SPECHT, M.J.; SANTOS, B.A; MARSHALL, N.; MELO, F.P.L.; LEAL, I.; TABARELLI, M.; BALDAUF, C. Socioeconomic differences among resident, users and neighbour populations of a protected area in the Brazilian dry forest. In: Journal of Environmental Management, vol. 232, pg. 607-614, 2019.

SIRVINSKAS, L.P. Manual de Direito Ambiental. 17 ed. São Paulo: Saraiva, 2017.

STRECK C; RAJÃO R. Options for Enhancing REDD+ Collaboration in the Context of Article 6 of the Paris Agreement. Washington: Meridian Institute, 2017.

STRECK, L. Do pamprincipiologismo à concepção hipossuficiente de princípio: Dilemas da crise do direito. In: Revista de Informação Legislativa, v.194, p.7-21, 2012.

S.O.S MATA ATLÂNTICA; INSTITUTO NACIONAL DE PESQUISAS ESPACIAIS INPE. Atlas dos remanescentes florestais da mata atlântica período 2013-2014. São Paulo: Fundação S.O.S Mata Atlântica, 2015.

SUNDFELD, C. A. Direito administrativo para céticos. São Paulo: Malheiros, 2012.

PETERSEN, R; DAVIS C., HEROLD M; DE SY, V. Tropical forest monitoring: Exploring the gaps between what is required and what is possible for REDD+ and other initiatives. Washington: World Resources Institute (WRI), 2018

TEIXEIRA, A. V.; GIRELLI, C. S. Direito ambiental comparado: Argentina, Brasil e o estudo normativo-jurídico de suas águas. In: Revista Eletrônica Direito e Política, v.10, n.3, p.1745-1772, 2015.

TONI, F. Decentralization and REDD+ in Brazil. Forest, vol.2, p.66-85, 2011. 
UMUNAY, P; LUJAN, B.; MEYER, C.; COBIÁN, J. Trifecta of Success for Reducing Commodity-Driven Deforestation: Assessing the Intersection of REDD+ Programs, Jurisdictional Approaches, and Private Sector Commitments. In: Forest, vol. 9, 01-13, 2018.

UN-REDD Programme Fund. 9th Consolidated Annual Progress Report of the UN-REDD Programme Fund, 2018. Disponível em: <https://unredd.net/documents/programmeprogress-reports-785/2017-programmeprogress- reports/16895-ninth-consolidated-annualprogress-report-of-the-un-redd-programme-fund-lowresolution. Html>. Acesso em: Dez de 2018.

UNFCCC. Addressing the Drivers of Deforestation and Forest Degradation. Disponível em: <https://unfccc.int/resource/docs/2013/cop19/eng/10a01.pdf\#page=43> Acesso em: Jan. de 2019.

Report of the Conference of the Parties on its twenty second session, held in Marrakech from 7 to 18 november 2016. Geneva: UNFCCC, 2017.

The Cancun Agreements: Outcome of the work of the Ad-Hoc Working Group on Long-Term Cooperative Action under the Convention. Decisões 1/CP.16. Disponível em: $<$ http://unfcc.int/resource/docs/2015/cop19/eng/10a01.pdf\#page=24 2 . Acesso em: 02 nov. 2018.

VEIGA, J.E. Desenvolvimento sustentável: o desafio do século XXI. Rio de Janeiro: Garamond, 2010.

VILLA, P.M.; MARTINS, S.V.; OLIVEIRA NETO, S.N.; RODRIGUES, A.C. Predictores antropogénicos y biofísicos de deforestación en la Amazonía: hacia la integración de actividades REDD+. Bosque, vol. 38, n.3, 433-446, 2017. 